INSTITUTO DE PESQUISAS ENERGÉTICAS E NUCLEARES

Autarquia associada à Universidade de São Paulo

\title{
ANÁLISE SOBRE A PREDISPOSIÇÃO DO CONSUMIDOR EM ARCAR COM O CUSTO DO ALIMENTO PROCESSADO POR RADIAÇÃO IONIZANTE
}

\author{
ELIANA BORBA CATTARUZZI
}

Tese apresentada como parte dos requisitos para obtenção do Grau de Doutor em Ciências na Área de Tecnologia Nuclear - Aplicações.

Orientador:

Dra. Anna Lucia C. H. Villavicencio

Co-orientador:

Dr. Valter Arthur

SÃO PAULO 
Aos meus pais Antonio e Nilza pela oportunidade, apoio, dedicação, incentivo, paciência e carinho durante a realização deste trabalho. 


\section{AGRADECIMENTOS}

A Deus, por toda luz, força, coragem e energia em todos os momentos deste caminho, me carregando nos seus braços.

À Dra. Anna Lucia Casañas Haasis Villavicencio pela valiosa orientação, pela confiança depositada, pela motivação, incentivo e paciência, pelas importantes contribuições e sugestões que enriqueceram ainda mais o conteúdo desta pesquisa.

Ao Dr. Valter Arthur pela valiosa co-orientação, pela confiança depositada, pelas importantes contribuições e sugestões, pela motivação, incentivo e paciência.

À Leila Modanez pela amizade verdadeira, companheirismo, carinho, apoio, incentivo, às contribuições constantes, imenso auxílio, muita paciência e por compartilhar comigo todas as fases desta conquista.

À Rita de Cássia Araujo Scaglione pela grande amizade, companheirismo, carinho, convívio, ajuda, incentivo e paciência em todos os momentos.

À Maria de Lourdes Ruegger Silva pela generosa amizade, carinho e incentivo em todas as etapas deste trabalho.

Às amigas Cinira, Edna, Marta e Marcia pela amizade, carinho e incentivo em todos os momentos.

Ao Centro Universitário Fundação Santo André pelo apoio e autorização para aplicação da pesquisa.

Aos meus alunos que se prontificaram a responder à pesquisa.

Ao Instituto de Pesquisas Energéticas e Nucleares pela acolhida durante 0 período deste trabalho e pelo apoio científico. 
À coordenação e ao corpo docente do Programa de Pós-graduação do IPEN/USP, pelo convívio, apoio e compreensão.

Aos professores doutores da Banca Examinadora, pela atenção, comentários e sugestões que tanto contribuíram para a evolução deste trabalho.

Às pessoas que mais amo neste mundo, meus pais, Nilza e Antonio por tudo que me ensinaram, ajudaram e incentivaram durante toda minha vida, a minha mais sincera e eterna gratidão.

Ao meu irmão e cunhada, Eduardo e Valéria pela amizade e compreensão durante toda esta etapa, e por terem me presenteado com minha linda sobrinha Maria Eduarda, cujo sorriso angelical me faz muito feliz.

A todos aqueles que, mesmo sem que eu tenha mencionado, direta ou indiretamente contribuíram para que fosse possível a realização deste trabalho. 
"A mente que se abre a uma nova ideia jamais voltará ao seu tamanho original".

\section{Albert Einstein}




\title{
ANÁLISE SOBRE A PREDISPOSIÇÃO DO CONSUMIDOR EM ARCAR COM O CUSTO DO ALIMENTO PROCESSADO POR RADIAÇÃO IONIZANTE
}

\author{
ELIANA BORBA CATTARUZZI
}

\section{RESUMO}

O conceito de qualidade dos alimentos, na visão do consumidor, reflete a satisfação de características como sabor, aroma, aparência, embalagem e disponibilidade. Fatores econômicos e sociais como o custo e hábitos alimentares geralmente também têm influência sobre a escolha do produto. $A$ irradiação é uma técnica eficiente na conservação dos alimentos, pois reduz as perdas naturais causadas pelos processos fisiológicos, além de eliminar ou reduzir microrganismos, parasitas e pragas, sem causar qualquer prejuízo ao alimento, tornando-os mais seguros ao consumidor; porém, pode haver aumento no custo dos alimentos. Pesquisas apontam que a praticidade é uma característica já incorporada pelo consumidor, o preço pode ser um fator de restrição à popularização do produto irradiado, embora alguns consumidores considerem que, devido ao fato de evitar desperdícios, o aumento do custo pode ser viável. O objetivo deste trabalho foi analisar o custo do uso da tecnologia de irradiação de alimentos e verificar se os consumidores, quando informados sobre as vantagens na segurança alimentar, estão dispostos a pagar por este tratamento, bem como o quanto estão dispostos a pagar. A metodologia consistiu em um estudo sobre a viabilidade econômica da implantação da tecnologia de irradiação de alimentos por meio de um levantamento sistemático da literatura especializada, com o intuito de verificar o custo de implantação e o acréscimo que o produtor terá em relação ao custo da tecnologia. Também foi realizada uma pesquisa em uma Instituição de Ensino Superior sobre a predisposição do consumidor em arcar com este custo. Os resultados do estudo indicam um acréscimo, ao produtor, que pode variar de US\$ 0,01 a US\$ 0,25 por quilograma e também indicam que $75 \%$ dos consumidores entrevistados aceitam pagar mais pelo alimento irradiado. A partir desses resultados, concluiu-se que quanto maior o poder aquisitivo, maior a predisposição em arcar com o acréscimo ao custo do alimento irradiado. 


\title{
ANALYSIS ON THE CONSUMER DISPOSITION TO AFFORD THE COST OF FOOD PROCESSED BY IONIZING RADIATION
}

\author{
ELIANA BORBA CATTARUZZI
}

\begin{abstract}
The concept of food quality, in the consumer point of view, reflects the satisfaction of characteristics such as flavor, aroma, appearance, packaging and availability. Economic and social factors, such as cost and eating habits, generally, also influence the choice of a product. Irradiation is an effective technique in food preservation because it reduces the losses caused by natural physiological processes, either reducing or eliminating microorganisms, parasites and pests without causing any damage to the foods and, thus, making them safer to consumers. Nevertheless, there may be an increase in the cost of foods. Research indicates that practicality is already a deep-rooted feature of consumers. The price may be a limiting factor to the popularization of the irradiated product, although some consumers consider that, due to the avoidance of waste, the increased cost may be feasible. The objective of this study was to analyze the cost of using food irradiation technology and verify (a) whether consumers, when informed of the benefits in food safety, are willing to pay for this treatment and (b) how much they are willing to pay. The methodology consisted of a study on the economic feasibility of food irradiation technology by means of a systematic survey of the literature, in order to verify the cost of this process implementation and the increase in costs for the producer. Also, a survey was conducted in an Institution of Superior Education about the consumer's willingness to pay for this higher price. The study results indicate a rise in costs to the producer, ranging from $\$ 0.01$ to U.S. $\$ 0.25$ per pound; it was also found that $75 \%$ of the consumers surveyed are willing to pay more for irradiated food. From these results it was concluded that the higher the consumption power is, the greater the willingness to afford the additional cost irradiated foods have.
\end{abstract}




\section{SUMÁRIO}

Página

LISTA DE TABELAS

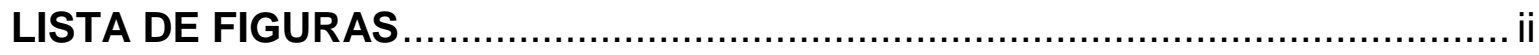

LISTA DE ABREVIAÇÕES E/OU SIGLAS ................................................. iv

1 - INTRODUÇÃO

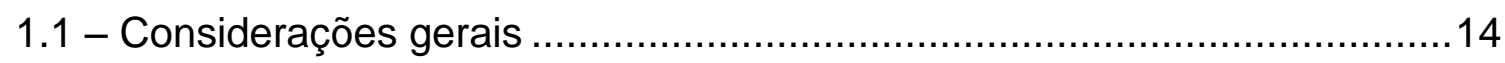

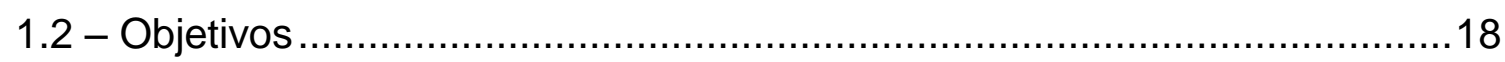

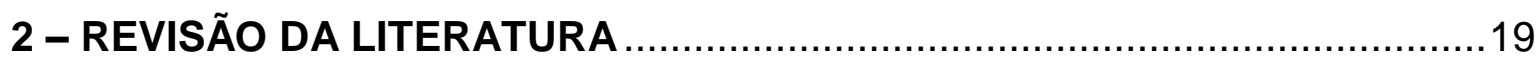

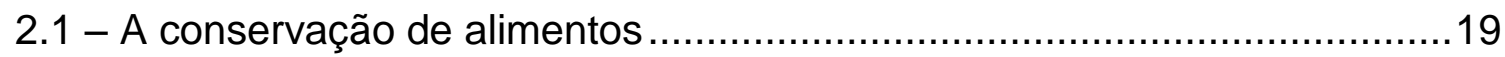

2.2 - Tipos de tratamentos para a conservação de alimentos ...........................21

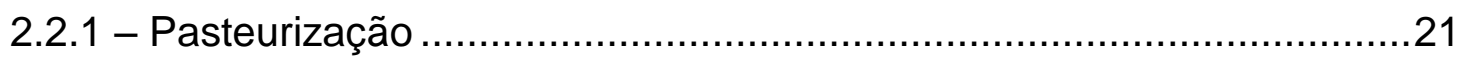

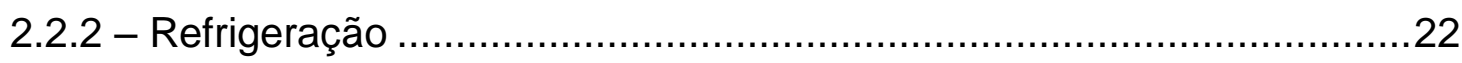

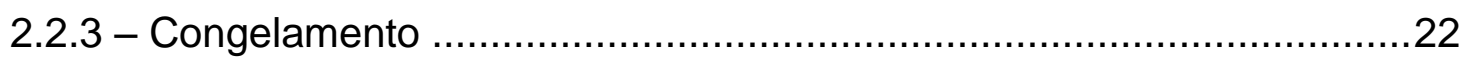

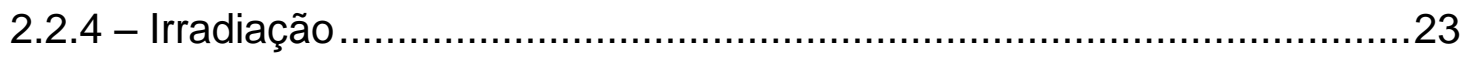

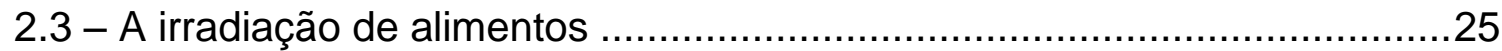

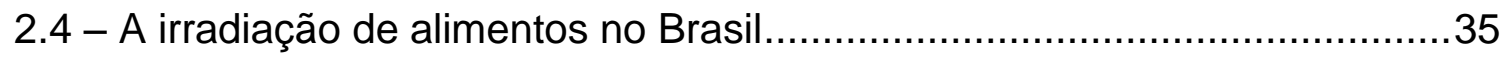

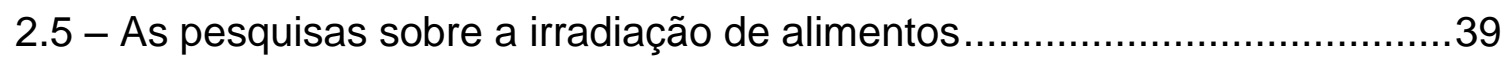

2.6 - As instalações para irradiação de alimentos no Brasil ...............................44

2.7 - As instalações para irradiação de alimentos no mundo ...............................48

2.8 - Oportunidades para o uso da tecnologia de irradiação..............................53

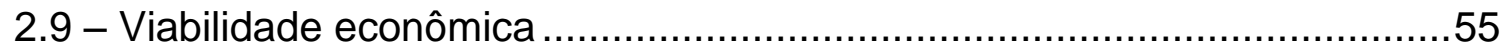

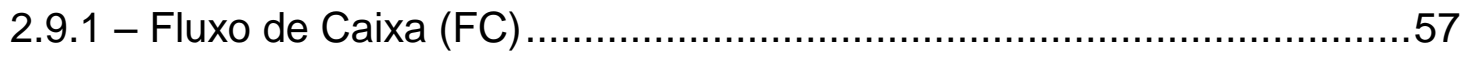

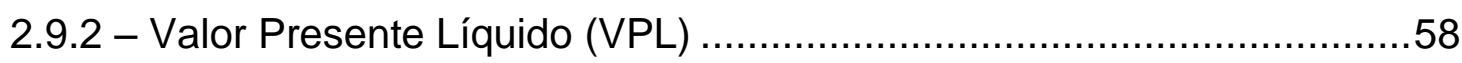

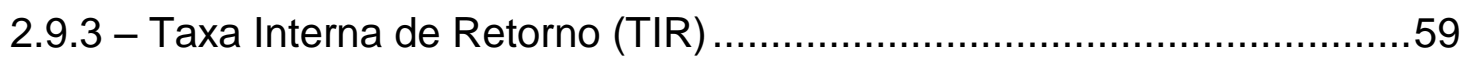

2.9.4 - Tempo de Retorno do Investimento (TRI) ou Método do Payback.....60

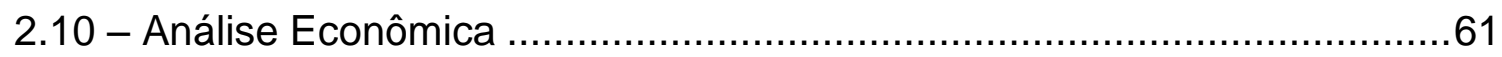

2.10.1 - Análise econômica para Packing House com sistema para irradiação contínua

2.10.2 - Análise econômica para Packing House com sistema hidrotérmico.63 
2.10.3 - Análise econômica para irradiadores de alimentos de Cobalto 60 $\left({ }^{60} \mathrm{Co}\right)$ .64

2.10.4 - Análise econômica para aceleradores de elétrons..........................66

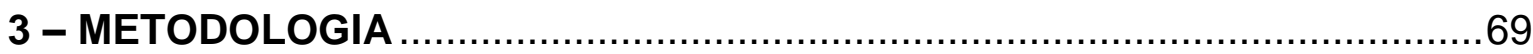

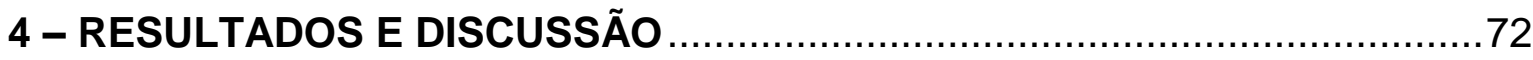

4.1 - Análise da viabilidade econômica ....................................................... 72

4.2 - Pesquisa sobre a predisposição dos consumidores em arcar com o custo do alimento processado por ionização ...............................................

4.2.1 - Análise da caracterização socioeconômica e demográfica .................75

4.2.2 - Análise do conhecimento sobre as aplicações da energia nuclear sem

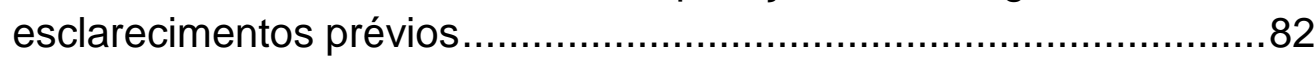

4.2.3 - Análise da intenção de compra de alimentos irradiados após os

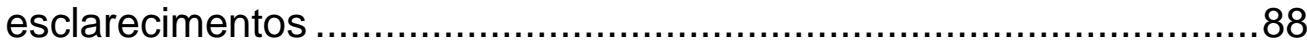

5 - CONCLUSÃO

ANEXOS

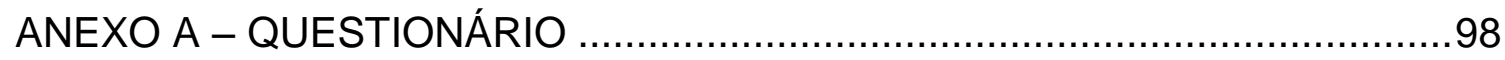

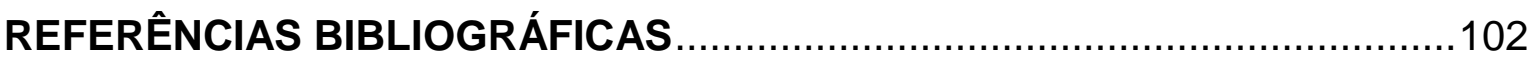




\section{LISTA DE TABELAS}

Página

TABELA - 1 Dose de irradiação aplicada a diversos alimentos.......................................................... 28

TABELA - 2 Histórico do progresso da irradiação de alimentos no mundo.......................................................... 32

TABELA - $3 \quad$ Vida útil de alimentos não irradiados e irradiados .......... 34

TABELA-4 Quantidade de instalações da África e Oceania e principais alimentos irradiados

TABELA - 5 Quantidade de instalações das Américas e principais alimentos irradiados

TABELA-6 Quantidade de instalações da Ásia e principais alimentos irradiados

TABELA-7 Quantidade de instalações da Europa e principais alimentos irradiados ............................................... 52

TABELA - 8 Caracterização socioeconômica e demográfica ............. 76

TABELA - 9 Informações sobre as aplicações da energia nuclear sem esclarecimentos prévios .................................. 82

TABELA - 10 Informações sobre a intenção de compra de alimentos irradiados após esclarecimentos 


\section{LISTA DE FIGURAS}

\section{Página}

FIGURA - 1 Exemplo de instalação para pasteurização ....................... 21

FIGURA - $2 \quad$ Exemplos de alimentos refrigerados ................................ 22

FIGURA - $3 \quad$ Exemplos de alimentos congelados .................................. 23

FIGURA - $4 \quad$ Exemplos de alimentos irradiados e não irradiados ........... 24

FIGURA - $5 \quad$ Exemplo de instalação para irradiação gama ..................... 25

FIGURA - $6 \quad$ Exemplo de instalação para utilização dos raios-x ............ 26

FIGURA - 7 Exemplo de instalação para aceleradores de elétrons ...... 26

FIGURA - $8 \quad$ CBE Embrarad ........................................................... 4

FIGURA - 9 Acelétron Irradiação Comercial ........................................ 46

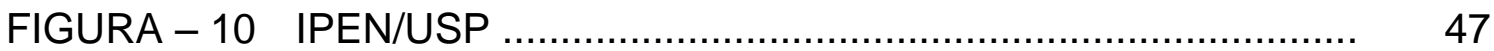

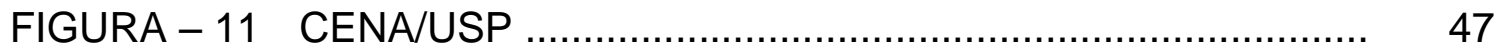

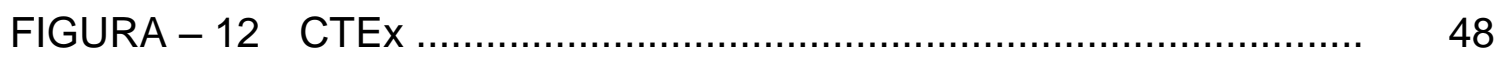

FIGURA - 13 Exemplo de Packing House para irradiação contínua ....... 62

FIGURA - 14 Exemplo de Packing House com sistema hidrotérmico ..... 63

FIGURA - 15 Exemplo de irradiador de Cobalto $60\left({ }^{60} \mathrm{Co}\right) \ldots \ldots \ldots \ldots \ldots \ldots \ldots . . . . . . . . . . .66$

FIGURA - $16 \quad$ Exemplo de acelerador de elétrons ..................................... 68

FIGURA - 17 Município de residência ..................................................... 78

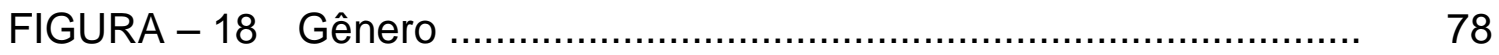

FIGURA - 19 Faixa etária ...............................................................

FIGURA - 20 Estado Civil ................................................................ $\quad 79$

FIGURA - 21 Número de filhos .......................................................... 80

FIGURA - 22 Grau de escolaridade ................................................. $\quad 80$

FIGURA - 23 Faixa salarial pessoal mensal ........................................ 81

FIGURA - $24 \quad$ Faixa salarial familiar mensal .......................................... 82

FIGURA - 25 Quando você ouve falar em energia nuclear, a impressão que você tem é.............................................................. 84 
FIGURA-26 Você sabia que materiais farmacêuticos (fraldas descartáveis, gazes, seringas, agulhas, etc) e alguns cosméticos disponíveis no mercado são esterilizados por meio da irradiação ?

FIGURA - 27 Você sabia que uma das aplicações da energia nuclear é a irradiação de alimentos ?

FIGURA - 28 Você se preocupa com a qualidade dos alimentos que consome?

FIGURA - 29 Você acredita que a irradiação produz toxinas nos alimentos ou acarreta perda de nutrientes?

FIGURA - 30 Você consumiria alimentos irradiados?

FIGURA - 31 As explicações sobre as aplicações da energia nuclear foram esclarecedoras?

FIGURA - 32 Os esclarecimentos sobre a irradiação de alimentos foram importantes para você?

FIGURA - 33 Depois dos esclarecimentos sobre a irradiação de alimentos, você compraria alimentos irradiados?

FIGURA - 34 Em se tratando da segurança alimentar, você estaria disposto a pagar a mais por essa segurança?

FIGURA - 35 O preço do alimento irradiado influenciaria na sua decisão de compra?

FIGURA - 36 Sabendo que a irradiação de alimentos aumenta a segurança alimentar, quanto você estaria disposto a pagar a mais por essa segurança? 


\section{LISTA DE ABREVIAÇÕES E/OU SIGLAS}

ANVISA

CAC

CBE

CDTN

CENA

CGEE

${ }^{137} \mathrm{Cs}$

CNEN

${ }^{60} \mathrm{Co}$

CTEX

CTR

CUFSA

DQBN

DTA

ESALQ

FAFIL

FAO

FC

FDA

Gy

IAEA

IBGE

ICGFI

IPEN

$\mathrm{kCi}$

kGy

LINAC

MAPA

$\mathrm{PBq}$

PIB

$\mathrm{RDC}$
Agência Nacional de Vigilância Sanitária

Codex Alimentarius Commission

Empresa Brasileira de Radiações

Centro de Desenvolvimento da Tecnologia Nuclear

Centro de Energia Nuclear na Agricultura

Centro de Gestão de Estudos Estratégicos

Césio 137

Comissão Nacional de Energia Nuclear

Cobalto 60

Centro tecnológico de Exército

Centro de Tecnologia das Radiações

Centro Universitário Fundação Santo André

Defesa Química, Biológica e Nuclear

Doenças Transmitidas por Alimentos

Escola de Agronomia Luiz de Queiroz

Faculdade de Filosofia, Ciências e Letras

Food and Agriculture Organization

Fluxo de Caixa

Food and Drugs Organization

Gray

International Atomic Energy Agency

Instituto Brasileiro de Geografia e Estatística

International Consultative Group on Food Irradiation

Instituto de Pesquisa Energéticas e Nucleares

QuiloCurie

QuiloGray

Linear Particle Accelerator

Ministério da Agricultura, Pecuária e Abastecimento

PetaBequerel

Produto Interno Bruto

Resolução da Diretoria Colegiada 
THT

Tratamento Hidrotérmico

TIR

Taxa Interna de Retorno

TMA

Taxa Mínima de Atratividade

TRI

Tempo de Retorno do Investimento

TRL Türk Lirasi

USDA

United States Departament of Agriculture

USP

Universidade de São Paulo

VPL

Valor Presente Líquido

WHO

World Health Organization

YTL

Yene Türk Lirasi 


\section{1 - INTRODUÇÃO}

\section{1- Considerações gerais}

As radiações ionizantes são consideradas um fenômeno natural existente em nosso planeta desde sua origem. A utilização das radiações ionizantes em benefício do homem, ao final do século XIX, tornaram evidentes seus efeitos na saúde humana e a primeira proposta documentada para seu uso na conservação de alimentos surgiu em 1905, por meio dos ingleses Appleby e Banks (CENA/USP, 2012a).

O processo consiste na exposição dos alimentos, embalados ou a granel, a radiações ionizantes como raios gama, raios-x ou feixe de elétrons. A fonte mais comum, de raios gama para o processamento de alimentos é o radioisótopo Cobalto $60\left({ }^{60} \mathrm{Co}\right)$. A irradiação de alimentos ocorre em temperatura ambiente, portanto, o alimento pode ser acondicionado em embalagens antes de ser irradiado.

O crescimento rápido da população mundial e a consequente falta de alimentos levou o homem a criar tecnologias que possam atender ao fornecimento de alimentos de forma mais segura e duradoura. $\mathrm{O}$ uso da radiação ionizante, no tratamento de alimentos, já é estudado há muitos anos e, desde 1963, está regulamentado pela U.S. Food and Drugs Administration (FDA); mas, em 1997, uma conferência da World Health Organization (WHO), realizada em Genebra, Suíça, estabeleceu que este tratamento não é nocivo à saúde e liberou a utilização da técnica para todo tipo de alimento.

O Brasil segue as recomendações internacionais da International Atomic Energy Agency (IAEA), Food and Agriculture Organization (FAO), Codex Alimentarius Commission (CAC), as normas descritas na Resolução RDC ํㅡㄹㅡ. de 26 de janeiro de 2001, da Agência Nacional de Vigilância Sanitária (ANVISA), 
e a Instrução Normativa ำ 9, de 24 de fevereiro de 2011, do Ministério da Agricultura, Pecuária e Abastecimento (MAPA) (Brasil, 2001; 2011).

O processo da radiação ionizante, quando bem conduzido, não implica em danos ambientais ou à saúde humana, sendo apoiado por instituições como a World Health Organization (WHO), Food and Agricultural Organization (FAO), U.S. Food and Drugs Administration (FDA) e a Agência Nacional de Vigilância Sanitária (ANVISA).

O tratamento de alimentos por radiação ionizante como raios gama, raios-x ou feixe de elétrons é o tratamento do alimento por exposição a uma quantidade controlada de radiação, por um tempo específico, para obter os objetivos desejáveis. É uma tecnologia utilizada em vários países para garantir a qualidade e segurança dos alimentos e já é utilizada regularmente aqui no Brasil para ingredientes e especiarias na preparação de alimentos industrializados (CENA/USP, 2012a), justificando a vantagem ambiental associada a este método se comparada a métodos convencionais de tratamento de alimentos (Boaventura, 2004).

Este processo aplicado segundo recomendações internacionais contidas na legislação brasileira, não eleva o nível normal de radioatividade do alimento independente do tempo durante o qual o produto é exposto à radiação, ou o quanto de dose de energia é absorvida. Os alimentos irradiados não ficam radioativos após este procedimento (Murano et al., 1995).

O principal objetivo dos estudos sobre a irradiação de alimentos é oferecer aos consumidores alimentos com uma melhor qualidade e higiene, conservando sempre as propriedades nutricionais dos alimentos. Uma das finalidades da irradiação de alimentos é aumentar o tempo de prateleira dos alimentos, pois é muito comum ocorrer deterioração do alimento durante o período de armazenamento e transporte, devido à reprodução de microrganismos deteriorantes que se multiplicam rapidamente nos alimentos causando sabores e odores desagradáveis. O processamento pela irradiação, para alguns alimentos é seguro e eficiente, mas é fundamental que não se dispense as boas práticas de 
manuseio e fabricação, já que o processamento por irradiação não pode melhorar a má qualidade de produtos alimentícios ou uma manipulação indevida, pois, não reverte o processo fisiológico e químico da decomposição (Delincée, 1998; Villavicencio, 1998).

Qualquer método de processamento alimentar, como congelamento, pasteurização, refrigeração, irradiação, entre outros, irá adicionar custos para os alimentos, mas estes tratamentos também trazem benefícios para os consumidores em termos de durabilidade, conveniência e melhor higiene dos alimentos.

Atualmente, os equipamentos mais utilizados para a irradiação de alimentos são os irradiadores de Cobalto $60\left({ }^{60} \mathrm{Co}\right)$. Esses equipamentos consistem numa fonte de Cobalto $60\left({ }^{60} \mathrm{Co}\right)$ instalada numa câmara de irradiação, blindada por paredes de concreto. Essa fonte, quando não está em operação, fica armazenada numa piscina (poço) de água deionisada, revestida por um liner (revestimento) de aço inoxidável, no interior da blindagem. Os alimentos a serem irradiados são colocados em containers e, através de um monotrilho, são conduzidos ao interior da câmara de irradiação, onde recebem a dose programada de radiação gama. Operadores qualificados controlam e monitoram eletronicamente a fonte de radiação e o tratamento dos produtos, através de uma bancada situada fora da câmara de irradiação (CENA/USP, 2012b).

O tratamento do alimento também pode ser feito utilizando-se um acelerador de partículas. Esses equipamentos são chamados de Linear Particle Accelerator e são máquinas capazes de gerar energia a partículas carregadas (prótons, elétrons, etc.), aumentando sua velocidade até muito próximo da velocidade da luz. Existem vários tipos de aceleradores, mas todos utilizam campos eletromagnéticos para fornecer a energia e para confinar e direcionar as partículas. O acelerador linear é o componente principal do sistema, é posicionado verticalmente e é onde os elétrons são gerados, concentrados na forma de feixe e acelerados. Como não existem partes móveis no acelerador linear, a sua manutenção é baixa. Neste tipo de instalação, os produtos são levados para a área de processamento através de um sistema de esteiras 
projetadas especificamente para operar em uma instalação de irradiação industrial de maneira a assegurar que os produtos sejam corretamente posicionados para uma irradiação uniforme e eficiente. Esta tecnologia não utiliza gases ou material radioativo, usando somente a energia elétrica como fonte de energia e, portanto, sendo assim fácil de ligar e de desligar o equipamento. (Acelétron, 2011).

O uso desta tecnologia é aplicado a uma grande diversidade de produtos de várias áreas, tais como material médico, cosméticos, fitoterápicos, polímeros, turfa, gemas e alimentos dentre outros.

Para se operar um irradiador comercial, os custos são basicamente o investimento inicial de máquina e equipamentos, transporte, obras e instalações e os custos operacionais. Estes são os recursos necessários para o ajuste da operação, realizada antes do início do funcionamento do irradiador, fortemente ligados aos fatores de segurança. Depois do início da operação, começa a recuperação do investimento inicial e é importante destacar que o tempo de recuperação depende do uso adequado, em relação à demanda, do tipo de produto e do tempo que este produto leva para ser irradiado, de acordo com as especificações técnicas, que determinam o volume final da produção. Devido ao alto investimento inicial, é necessário afirmar que o irradiador deve operar no máximo de sua capacidade, processando preferencialmente produtos que tenham alto valor agregado ao serem irradiados. O cálculo do retorno do investimento considera o preço de venda do alimento e a redução do custo com a diminuição da estocagem.

Segundo Ornellas et al. (2006), apesar de toda a regulamentação e controle no emprego da irradiação, diversas barreiras ainda persistem e impedem que os alimentos irradiados alcancem a completa comercialização, principalmente as relacionadas ao custo de sua utilização e à aceitação pelo consumidor.

O consumidor quer ser informado sobre tudo o que está comendo e isto não é uma postura somente frente aos produtos irradiados. A praticidade é uma característica já incorporada pelo consumidor; porém, o preço pode ser um 
fator que restrinja a popularização do produto, embora alguns consumidores já considerem que, por evitar desperdícios e facilitar o preparo, os preços se tornam aceitáveis. As atitudes estudadas até agora demonstram que mais da metade dos consumidores esperam e estão dispostos a pagar mais por alimentos irradiados (Bruhn \& Schultz, 1989; Resurreccion et al., 1995).

O preço dos alimentos irradiados poderá diminuir conforme este método tornar-se mais amplamente disponível. Incentivar o comércio internacional de produtos alimentícios deve satisfazer os elevados padrões de qualidade, a fim de ultrapassar nossas fronteiras (Kuramoto, 2008).

O Brasil tem chances de expandir ainda mais as exportações de frutas para exigentes mercados consumidores, pois a Instrução Normativa $n \div 9$ reconhece o uso da radiação ionizante como tratamento fitossanitário, cujo objetivo é prevenir a introdução ou disseminação de pragas quarentenárias, ou seja, aquelas que têm impacto nas exportações e importações (Brasil, 2011).

\section{2 - Objetivos}

Os objetivos desse trabalho foram:

- analisar o custo do uso da tecnologia de irradiação de alimentos;

- verificar se os consumidores, quando informados sobre as vantagens na segurança alimentar que os produtos tratados pela radiação ionizante trazem, estão dispostos a pagar por essa segurança;

- verificar quanto os consumidores estão dispostos a pagar por estes produtos. 


\section{2 - REVISÃO DA LITERATURA}

\section{1 - A conservação de alimentos}

Segundo a Food and Agricultural Organization (FAO, 2011), nos países em desenvolvimento, mais de 1 bilhão de pessoas sofrem de desnutrição crônica, comendo menos do que o necessário para atingir níveis mínimos de energia, e milhões sofrem de subnutrição aguda nos períodos de falta sazonal ou transitória de alimentos. A World Health Organization (WHO, 1995), concluiu que $70 \%$ das 3,2 milhões de mortes anuais de crianças menores de cinco anos são decorrentes de doenças provocadas por agentes patogênicos, transmitidos por alimentos.

As técnicas de preservação de alimentos, ao longo dos anos, foram se desenvolvendo conforme o aumento do conhecimento científico. Com a intenção de aumentar a qualidade do alimento, para a melhoria da saúde pública ou para prolongar a sua vida útil, vários são os métodos de conservação disponíveis para as indústrias de alimento.

Os processos de conservação têm por objetivo evitar as alterações nos alimentos e baseiam-se na destruição total ou parcial dos microrganismos capazes de alterá-los e na modificação ou eliminação de um ou mais fatores que são essenciais para sua multiplicação, de modo que o alimento não se torne propício ao desenvolvimento microbiano, que ocorre em função do tipo de alimento e das condições ambientais (Azeredo, 2004).

A produção, conservação e a distribuição de alimentos são problemas estratégicos a serem resolvidos com a máxima urgência, pois como se sabe, o crescimento populacional é mais acelerado do que a disponibilidade de alimentos. A produção de alimentos não é tudo; se não houver meios adequados para conservá-los e distribui-los, o problema da alimentação da população mundial não 
irá tão somente persistir, mas, será agravado (Villavicencio, 1998; 2007).

Segundo o Codex (2010), os alimentos devem estar devidamente protegidos durante o transporte; podem ser contaminados ou podem não chegar a seu destino em condições adequadas para o consumo, a menos que sejam adotadas medidas de controle eficazes para protegê-los de fontes potenciais de contaminação, bem como contra danos capazes de tornar o alimento inadequado para consumo e para proporcionar um ambiente que permita controlar, de forma eficaz, a multiplicação de microrganismos patogênicos ou deteriorantes e a produção de toxinas nos alimentos. Os meios de transporte ou os recipientes exigidos dependem da natureza do alimento e das condições em que ele deve ser transportado, mantido em adequado estado de limpeza, conservação e funcionamento.

As informações destinadas aos usuários da indústria ou do comércio devem ser claramente distintas das informações aos consumidores, especificamente nas rotulagens dos alimentos. Informações insuficientes sobre os produtos e/ou conhecimento inadequado sobre higiene dos alimentos podem conduzir à inapropriada manipulação dos produtos nas etapas posteriores da cadeia de alimentos. A manipulação inadequada pode resultar em doenças ou em produtos impróprios para consumo, mesmo quando medidas de controle de higiene tenham sido tomadas em etapas anteriores da cadeia de alimentos. Todos os produtos alimentícios devem ser acompanhados ou apresentar informações que permitam à próxima pessoa desta cadeia manipular, expor, armazenar, preparar e utilizar o produto de forma segura e correta.

Programas de educação para a saúde devem abordar o tema de higiene geral dos alimentos para que os consumidores adquiram conhecimento suficiente sobre a higiene dos alimentos e compreendam a importância das informações. Tais programas devem possibilitar aos consumidores a compreensão da importância de todas as informações sobre os produtos, seguindo todas as instruções que os acompanham, fazendo com que os consumidores evitem a contaminação, multiplicação ou sobrevivência de patógenos transmitidos por alimentos através de armazenamento, preparação e 
uso correto dos alimentos (Codex, 2010).

\section{2 - Tipos de tratamentos para a conservação de alimentos}

\subsection{1 - Pasteurização}

A pasteurização de alimentos é um tratamento térmico que tem, como objetivo principal, a eliminação de microrganismos presentes no alimento e, como objetivo secundário, aumentar a vida de prateleira do alimento. Utiliza temperaturas inferiores a $100^{\circ} \mathrm{C}$, visando à inativação de enzimas e à destruição de organismos sensíveis a temperaturas mais elevadas, como bactérias vegetativas, bolores e leveduras, sem modificar significativamente o valor nutritivo e as características organolépticas dos alimentos. O aquecimento é feito, normalmente, por vapor de água, em equipamentos em que o alimento percorre tubos, FIG1, e o vapor faz o aquecimento pelo lado externo dos tubos (CENA/USP, 2012c).

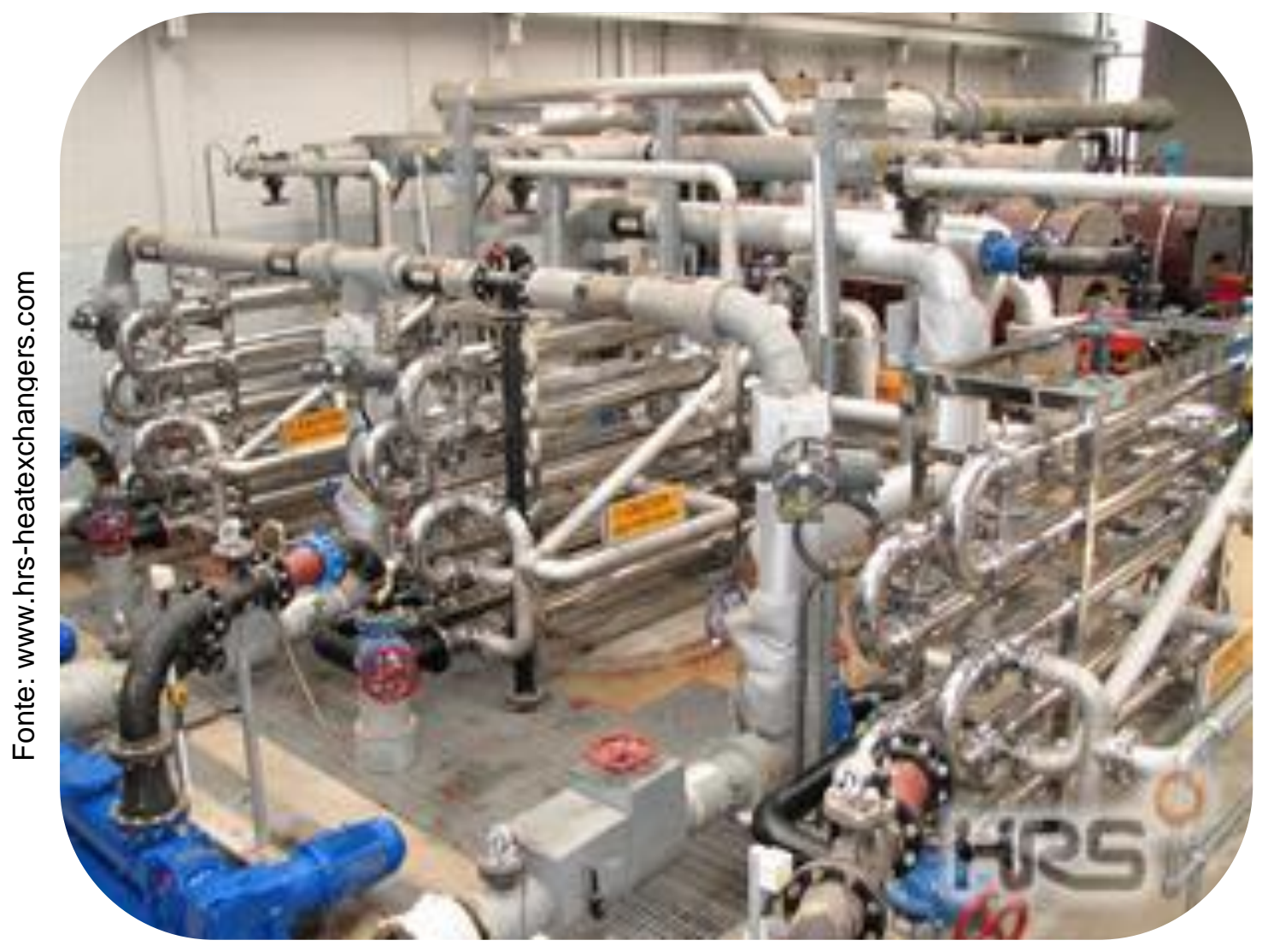

FIGURA 1 - Exemplo de instalação para pasteurização 


\subsection{2 - Refrigeração}

A refrigeração é um método de conservação dos alimentos que utiliza temperaturas entre $0^{\circ} \mathrm{C}$ e $7^{\circ} \mathrm{C}$, em geral, abaixo das que se tem registrado no ambiente e são utilizadas para retardar as reações químicas e as atividades enzimáticas. Na refrigeração, não ocorre eliminação dos microrganismos; como o impacto sobre as propriedades nutricionais e sensoriais é mais brando, conseguese atingir um menor tempo de conservação, ficando com o seu ciclo de reprodução inibido, retardando a deterioração dos alimentos. Pode ser usada como meio básico temporário até que se aplique outro método. $A$ temperatura dentro de uma câmara frigorífica não é uniforme; existem zonas mais frias do que outras e, por isso, mais adequadas a uns alimentos do que a outros, como ilustra a FIG.2 (CENA/USP, 2012d).
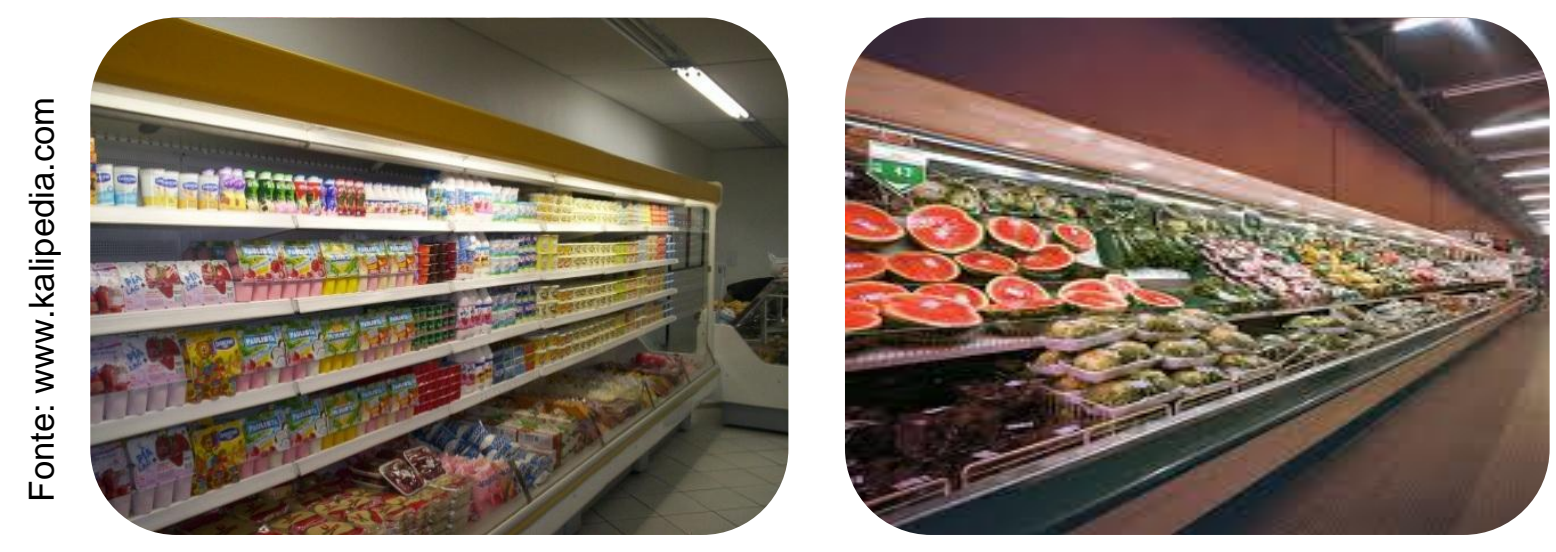

FIGURA 2 - Exemplos de alimentos refrigerados

\subsection{3 - Congelamento}

O congelamento dos alimentos frescos ou cozidos permite a sua conservação por um período de tempo mais longo, pois provoca a interrupção completa do crescimento dos microrganismos. O congelamento de alimentos é um método de conservação pelo frio que utiliza temperaturas que se situam entre - 10 e - 40ㄷ (FIG.3); neste processo de conservação, ocorre uma redução da população microbiana, mas não a sua eliminação. A morte dos microrganismos decorre dos cristais de gelo formados na célula, da desnaturação de enzimas, da perda de gases da célula e do abaixamento da atividade de água (CENA/USP, 2012d). 

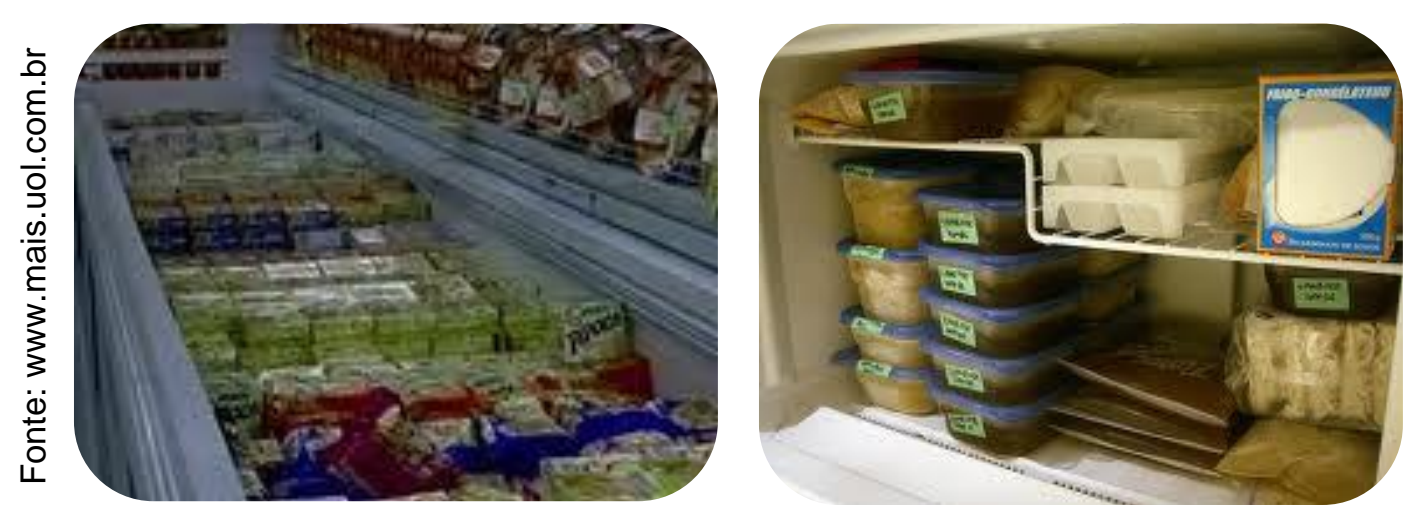

FIGURA 3 - Exemplos de alimentos congelados

\subsection{4 - Irradiação}

No emprego da radiação, estamos submetendo os alimentos a doses cuidadosamente controladas de uma radiação particular, a radiação ionizante. Do ponto de vista tecnológico, isto satisfaz plenamente o objetivo de proporcionar aos alimentos a estabilidade química e microbiológica, as condições de sanidade e o longo período de armazenamento. No método da irradiação de alimentos, o objetivo é a utilização de radiações que tenham boa penetração, mas de uma forma que não afetará somente os microrganismos localizados nas superfícies dos mesmos, mas em todo o alimento. O tratamento por irradiação pode ser aplicado para inibir o brotamento em bulbos e tubérculos; retardar a maturação e o envelhecimento em frutas e legumes; reduzir a carga microbiológica em carnes, frutas e legumes; eliminar pragas e parasitas em grãos, cereais, frutas e especiarias e para a esterilização em alimentos prontos para o consumo, que são conservados em temperatura ambiente (CENA/USP, 2012e).

Segundo Leal (2005), o uso da tecnologia de irradiação de alimentos melhoraria as relações econômicas do país, pois, com a crescente demanda por alimentos mais seguros, iríamos atender às exigências para importações, aumentando a nossa competitividade no mercado externo e o lucro dos nossos exportadores.

Os alimentos podem ser irradiados em qualquer estado: sólido, líquido, congelados ou não e em qualquer tipo de embalagem, como mostra a FIG.4 
(Hobbs \& Roberts, 1998).
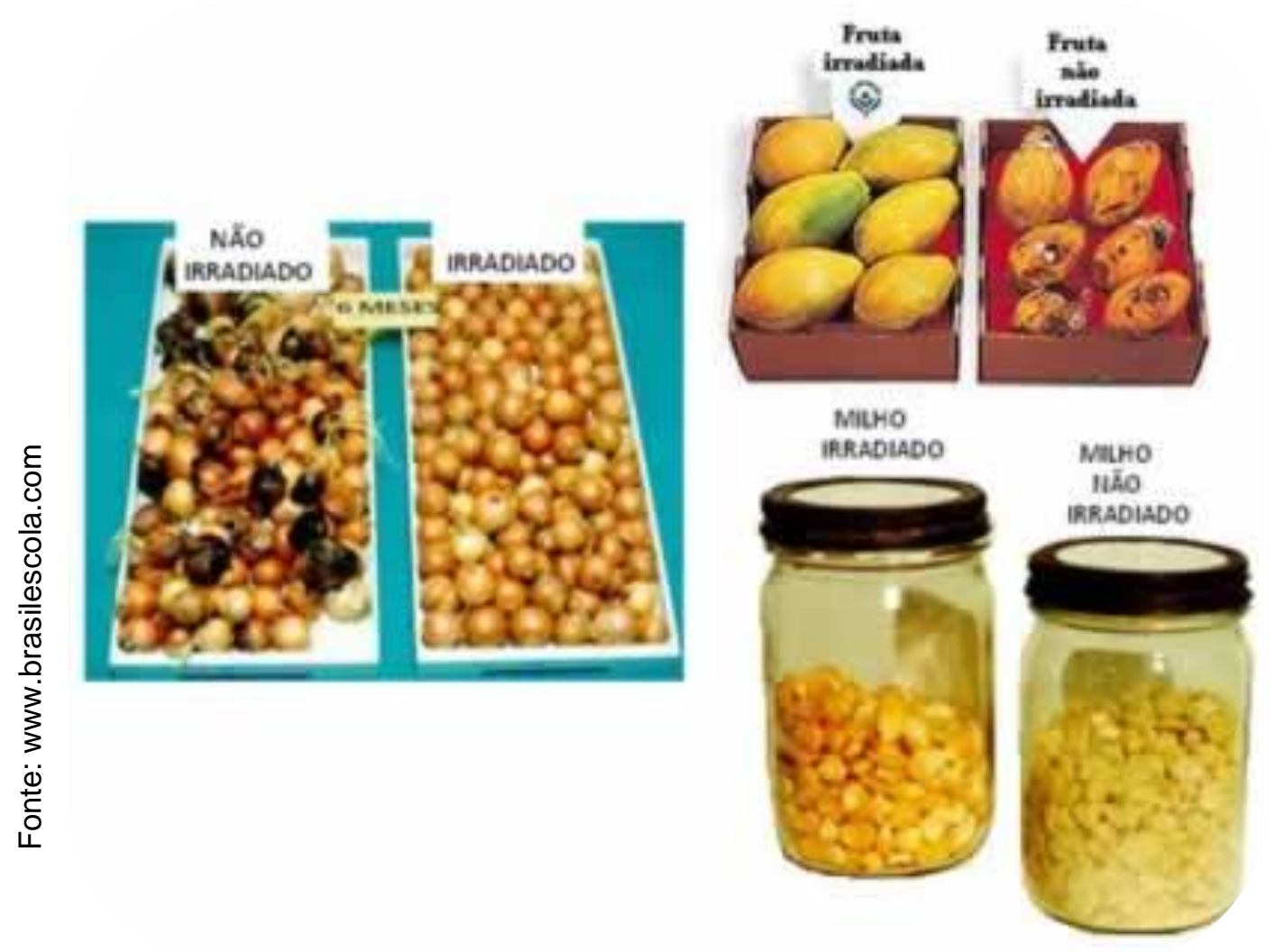

FIGURA 4 - Exemplos de alimentos irradiados e não irradiados

Os métodos de processamento alimentar, como pasteurização, refrigeração, congelamento, irradiação, entre outros, adicionam custos aos alimentos, mas estes tratamentos também trazem benefícios para os consumidores em termos de durabilidade, conveniência e melhor higiene dos alimentos.

As vantagens do uso da tecnologia de irradiação de alimentos são: seu custo competitivo quando há produção em larga escala, pois engloba só o custo fixo do irradiador e o da sua instalação; é uma técnica limpa por não causar impactos ambientais; mantém as qualidades nutricionais e preserva os aspectos sensoriais do alimento por não aumentar significativamente a temperatura do alimento, mantendo-o próximo ao seu estado natural; não deixa resíduos tóxicos e os alimentos podem ser irradiados já embalados, aumentando a segurança em sua armazenagem (Boaventura, 2004). 


\section{3 - A irradiação de alimentos}

A irradiação de alimentos é um método de conservação de alimentos que interessa aos cientistas da área de saúde pública desde o início do século XX. Sua aplicação pode ser uma forma efetiva de reduzir a incidência de doenças alimentares e no tratamento de vários problemas potenciais em nossa cadeia alimentar (Lima et al., 2001).

O processo de irradiação expõe os alimentos à energia ionizante, que pode vir de três fontes:

- Raios gama: são emitidos pelos radionuclídeos ${ }^{60} \mathrm{Co}$ ou ${ }^{137} \mathrm{Cs}$, com alto poder de penetração e fornecimento de boa uniformidade de dose, o que permite o tratamento de produtos com tamanho, densidade e formas variáveis. Apresenta uma baixa taxa de dose quando comparada à irradiação com feixe de elétrons e emissão da radiação não direcionada somente ao produto. A FIG.5 mostra um exemplo de equipamento para a irradiação por raios gama.

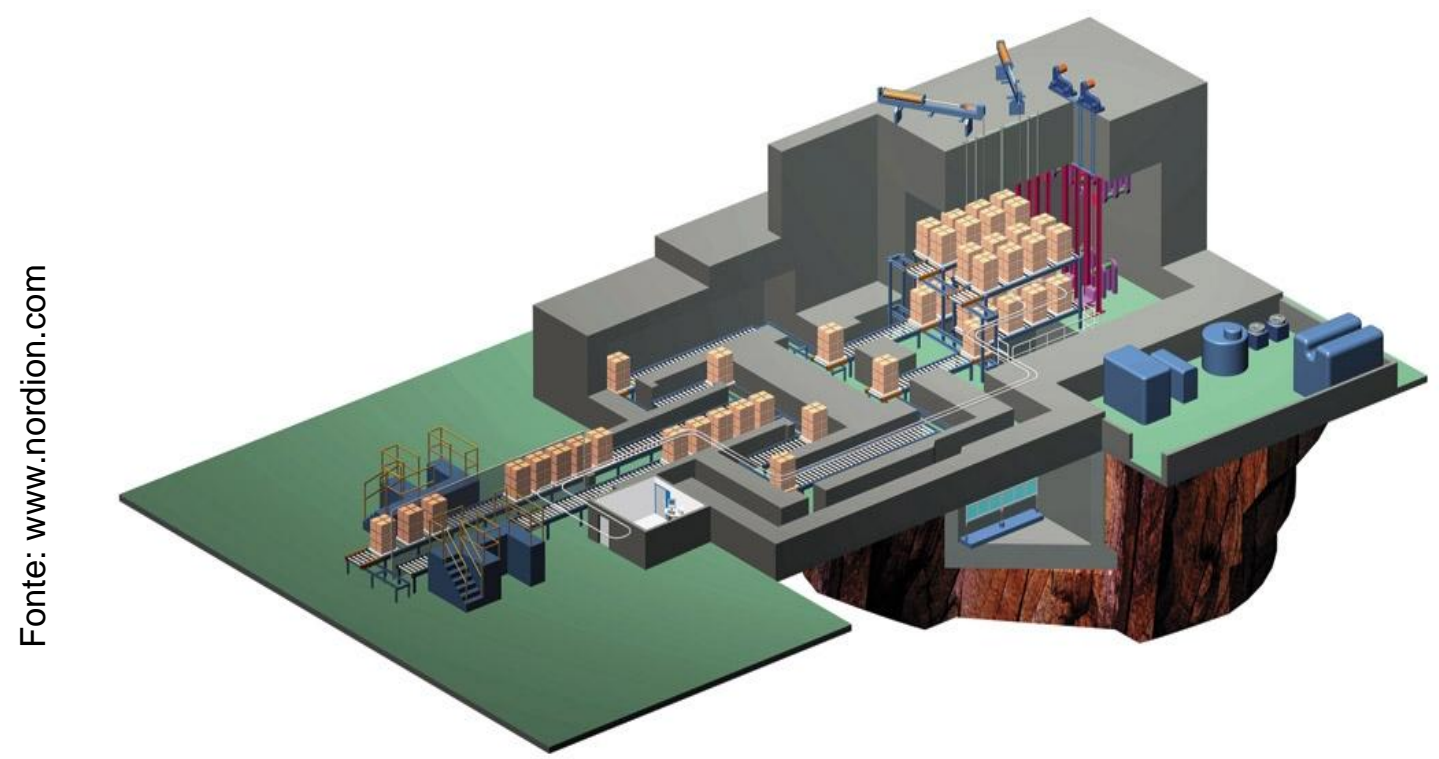

FIGURA 5 - Exemplo de instalação para irradiação gama

- Raios-x: gerados por máquinas operadas com energia máxima de $5 \mathrm{MeV}$, são produzidos quando um feixe de elétrons acelerados, com energia suficientemente alta, bombardeia um anteparo (alvo 
metálico de alto número atômico), reduzindo sua energia cinética. Os elétrons mudam de posição e emitem a diferença de energia sob a forma de ondas eletromagnéticas, chamadas de raios-x. A FIG.6 mostra um exemplo de equipamento para utilização de raios$\mathrm{x}$.

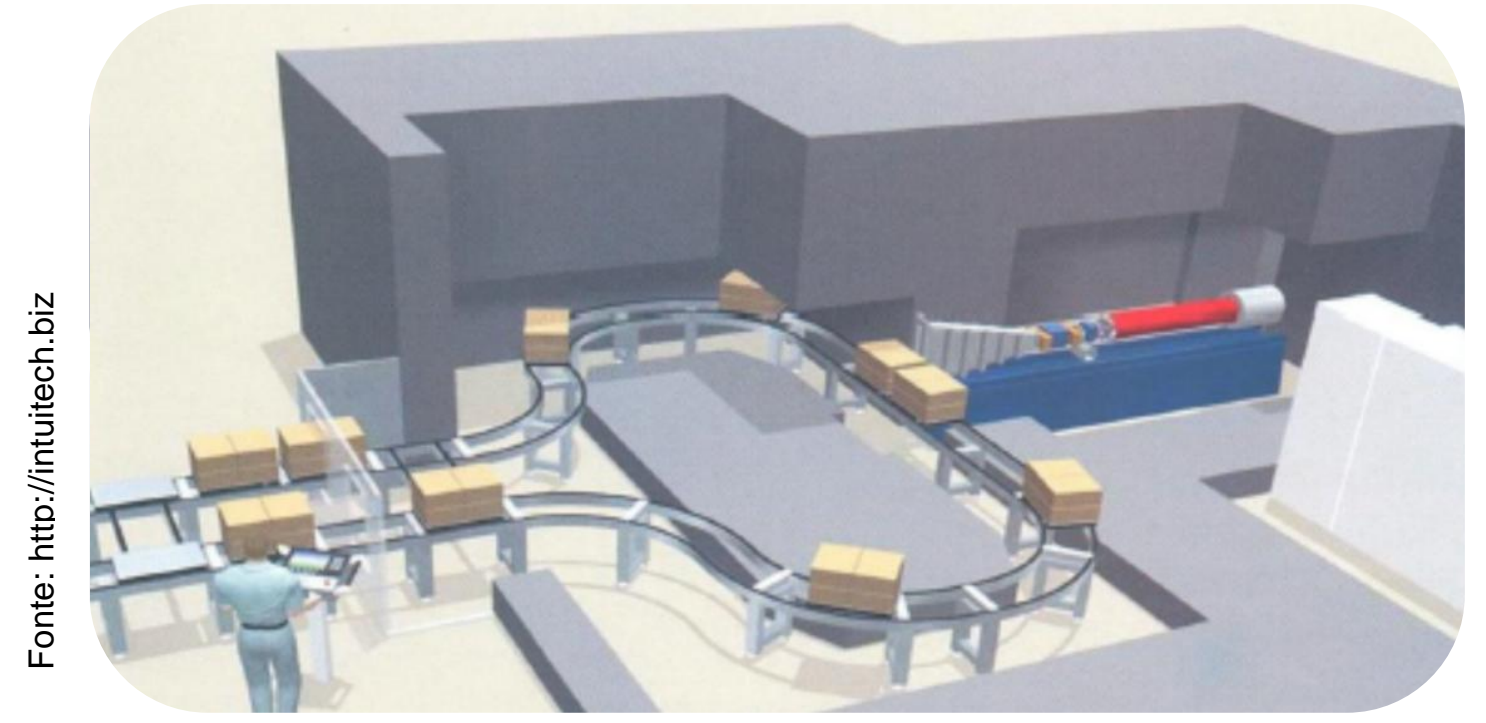

FIGURA 6 - Exemplo de instalação para utilização dos raios-x

- Aceleradores de elétrons: são gerados por equipamentos denominados aceleradores que produzem feixes de elétrons de alta energia e os aceleram a altas taxas de dose, produzindo milhões de kGy em frações de segundo. A energia máxima é de 10 MeV. A FIG.7 mostra um exemplo de equipamento para a aceleração de elétrons.

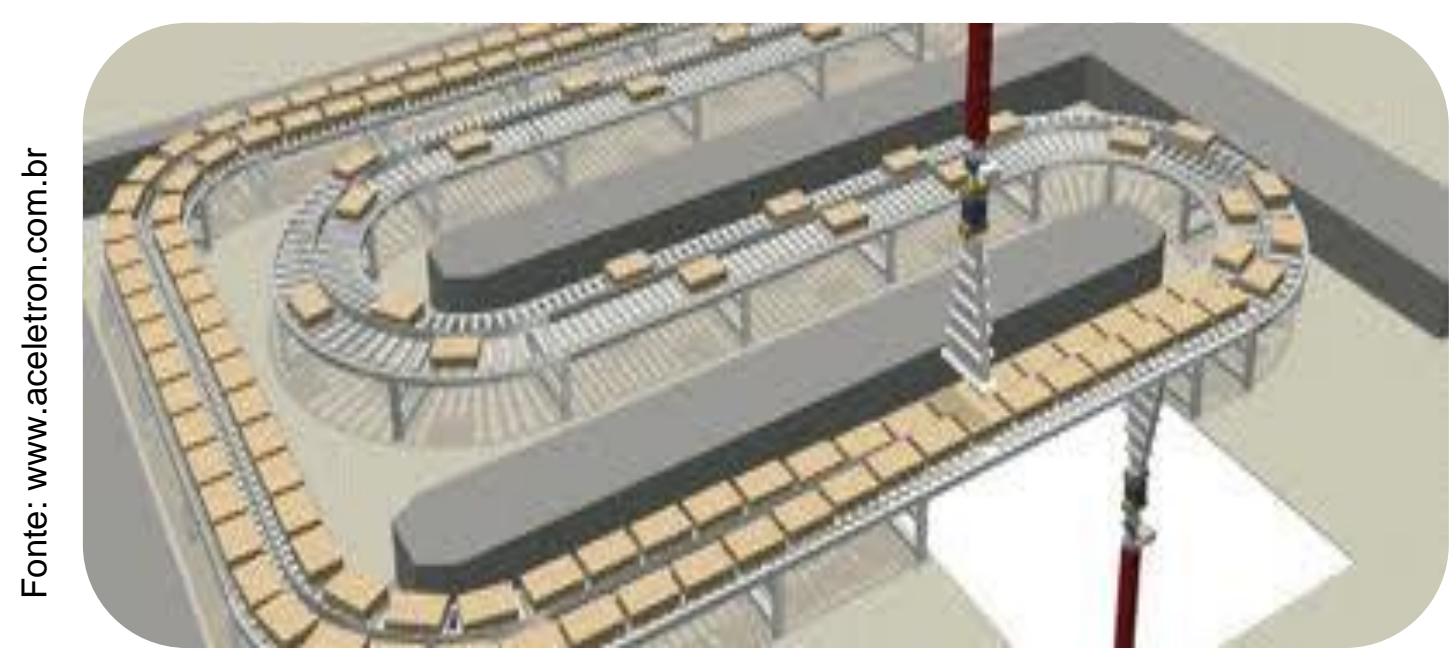

FIGURA 7 - Exemplo de instalação para aceleradores de elétrons 
A energia ionizante atravessa 0 alimento e a sua embalagem, reduzindo micróbios, bactérias, insetos, ovos ou larvas e parasitas (IAEA, 2010d).

As propriedades organolépticas da maioria dos alimentos não se alteram, desde que obedecidas às doses de radiação, recomendadas para cada tipo de alimento (Farkas, 2006).

As doses aplicadas variam de acordo com o objetivo desejado em cada tipo de alimento e são medidas em Gray (Gy) ou QuiloGrays (kGy) (01 Gray equivale a 01 Joule de energia por quilograma de alimento irradiado).

São consideradas:

- doses baixas, as menores que $1 \mathrm{kGy}$;

- doses médias, as que variam de 1 kGy a 10 kGy ;

- doses elevadas, as maiores que 10 kGy.

A técnica de irradiação não é adequada para todo tipo de alimento, pois acelera processos auto-oxidativos de gorduras, ocasionando a destruição de antioxidantes e a formação de radicais livres. Os produtos mais propensos são os gordurosos e os que contêm muita água disponível para reações como, por exemplo, o leite, que por ser um alimento com alto teor de gordura é tratado, atualmente, pela pasteurização.

A exposição dos alimentos à radiação, dependendo do produto e da dose empregada, inibe o brotamento, retarda o amadurecimento e destrói ou reduz para níveis aceitáveis, bactérias, parasitas, fungos, vírus e insetos. Se utilizado dentro dos limites permitidos pela legislação, não aumenta a temperatura e não deixa resíduos tóxicos, deixando-os o mais perto possível do seu estado natural. Os custos também são comparáveis aos processos tradicionais de tratamento (Urbain, 1986; Villavicencio et al, 2000).

A TAB.1 indica a dose de radiação aplicada a diversos alimentos de acordo com os regulamentos específicos, especifica qual é o propósito, as doses 
mínima e máxima recomendadas, em kGy, e mostra em que tipo de produto a radiação deve ser aplicada.

TABELA 1 - Dose de radiação aplicada a diversos alimentos

\begin{tabular}{|c|c|c|}
\hline Propósito & Dose (kGy) & Produtos \\
\hline \multicolumn{3}{|c|}{ Dose reduzida (< $1 \mathrm{kGy})$} \\
\hline Inibir a germinação. & $0,05-0,15$ & Batata, cebola, alho etc. \\
\hline Eliminar insetos e parasitas. & $0,15-0,50$ & $\begin{array}{l}\text { Cereais, legumes, frutas frescas } \\
\text { e secas, peixe e carnes frescos } \\
\text { e secos. }\end{array}$ \\
\hline $\begin{array}{l}\text { Retardar processos fisiológicos } \\
\text { (amadurecimento). }\end{array}$ & $0,50-1,0$ & Frutas e hortaliças frescas. \\
\hline \multicolumn{3}{|c|}{ Dose média (1 a 10 kGy) } \\
\hline Prolongar tempo de conservação. & $1,0-3,0$ & Peixe fresco, morangos etc. \\
\hline $\begin{array}{l}\text { Eliminar microrganismos } \\
\text { alternantes e patogênicos. }\end{array}$ & $1,0-7,0$ & $\begin{array}{l}\text { Marisco fresco e congelado, } \\
\text { carne de aves e de animais de } \\
\text { abastecimento crua ou } \\
\text { congelada. }\end{array}$ \\
\hline $\begin{array}{l}\text { Melhorar propriedades } \\
\text { tecnológicas do alimento. }\end{array}$ & $2,0-7,0$ & $\begin{array}{l}\text { Uvas (aumenta a produção de } \\
\text { suco), verduras desidratadas } \\
\text { (diminui o tempo de cocção). }\end{array}$ \\
\hline \multicolumn{3}{|c|}{ Dose elevada (10 a $50 \mathrm{kGy})^{a}$} \\
\hline $\begin{array}{l}\text { Esterilização industrial } \\
\text { (combinada com calor suave). }\end{array}$ & $30-50$ & $\begin{array}{llr}\text { Carne, } & \text { aves, } & \text { mariscos, } \\
\text { alimentos } & \text { prontos, } & \text { dietas } \\
\text { hospitalares } & \text { estéreis. } & \end{array}$ \\
\hline $\begin{array}{l}\text { Descontaminar certos aditivos } \\
\text { alimentícios e ingredientes. }\end{array}$ & $10-50$ & $\begin{array}{l}\text { Especiarias, preparações } \\
\text { enzimáticas, goma natural. }\end{array}$ \\
\hline
\end{tabular}

Fonte - CNEN, 2010.

Várias organizações internacionais, como a World Health Organization (WHO), Food and Agricultural Organization (FAO), U.S. Food and Drugs Administration (FDA) e International Atomic Energy Agency (IAEA), concluíram, 
após anos de pesquisas, que a irradiação de alimentos é um processo seguro e benéfico (Fumento, 1994; Loaharanu, 1994; Delincée et al., 1998; Spolaore et al., 2001).

Segundo Marchioni et al. (2005), quando comparada aos tratamentos químicos, proibidos atualmente, devido aos resíduos tóxicos, a irradiação de alimentos é uma alternativa mais atrativa e saudável para preservação e conservação a longo prazo. Além disso, a irradiação de alimentos atende a medidas de preservação ambiental, diminuindo gastos energéticos e riscos sanitários.

Por causa das necessidades mundiais na segurança dos alimentos e dos problemas existentes com a manipulação e com o armazenamento inadequados, há uma busca crescente por novos métodos de preservação de alimentos. A irradiação de alimentos é disponibilizada como um método de conservação, tanto do alimento in natura quanto como coadjuvante de processos industriais (Villavicencio, 1998).

É importante lembrar que a legislação internacional afirma que a irradiação deve ser usada em alimentos de boa qualidade, visando reduzir a deterioração posterior dos produtos e controlar a infestação e a contaminação por microrganismos; mas, nem a irradiação, nem outros métodos, podem eliminar os sinais externos de decomposição tornando os alimentos deteriorados aptos para o consumo, ou seja, deve-se somente irradiar alimentos com boa qualidade higiênica (Villavicencio, 1998; Maliska, 2000; Fan \& Sokoral, 2002).

Segundo Davies et al. (1995), as pessoas, em relação à própria saúde, têm consciência de que a escolha de produtos alimentícios é muito relevante.

Alguns conceitos influenciam o consumidor nas suas compras, a qualidade dos alimentos, que deve refletir características como aparência, embalagem, disponibilidade, aroma e sabor; os sociais, como os hábitos alimentares e os fatores econômicos, como o custo. Outros fatores, como o emprego das novas tecnologias e a legislação pertinente também têm se tornado 
fatores decisivos. O acesso dos consumidores aos métodos de processamento de alimentos e, particularmente, sobre a irradiação, ainda é muito limitado (Leonel, 2008).

Segundo Loaharanu \& Murrel (1994), desde que bem informados, não há evidências de que os consumidores não aceitem os alimentos irradiados.

A irradiação de alimentos, muito mais do que outros métodos de conservação de alimentos, precisou vencer as barreiras criadas por informações errôneas, prejudiciais, leis altamente restritivas e várias medidas regulatórias que, até os dias de hoje, vêm impedindo o uso irrestrito desta tecnologia (Diehl, 2002).

É também importante considerar que o emprego dessa tecnologia é estabelecido por diferentes regulamentos e normas, não só no Brasil, como no exterior, sendo proibida a comercialização de qualquer produto que não esteja de acordo com os pressupostos e exigências dos referidos regulamentos (CGEE, 2010).

É fundamental harmonizar as normas internacionais para garantir a segurança alimentar e evitar a introdução de pragas e doenças indesejáveis (IAEA, 2010b).

As infestações por pragas, que representam uma séria ameaça à segurança e adequação dos alimentos, podem ocorrer em locais que favoreçam a proliferação e onde haja disponibilidade de alimentos. Boas práticas de higiene devem ser empregadas para evitar a formação de um ambiente propício às pragas. A boa higienização, a inspeção de materiais recebidos e o bom monitoramento podem minimizar a probabilidade de infestação e, portanto, reduzir a necessidade do uso de pesticidas (Codex, 2010).

Segundo o Codex (2010), é direito dos cidadãos terem a expectativa de que os alimentos que consomem sejam seguros e adequados para consumo. As doenças e os danos provocados por alimentos são, na melhor das hipóteses, desagradáveis, e, na pior das hipóteses, fatais, mas há também outras 
consequências. Os surtos de Doenças Transmitidas por Alimentos (DTA) podem prejudicar o comércio e o turismo, causando perdas econômicas e desemprego. Os alimentos deteriorados causam desperdício e aumento de custos, afetando, de forma adversa, o comércio e a confiança do consumidor.

O comércio internacional de alimentos e as viagens internacionais estão cada vez mais frequentes e, como resultado disto, temos importantes benefícios socioeconômicos, mas também temos a disseminação de doenças ao redor do mundo. Em muitos países, nas últimas décadas, os hábitos alimentares têm passado por mudanças, acarretando o desenvolvimento de novas técnicas de produção, preparação e distribuição de alimentos; portanto, um controle eficaz de higiene tornou-se imprescindível para se evitarem consequências prejudiciais à saúde humana e à economia decorrentes de doenças e danos provocados pelos alimentos. Os agricultores e cultivadores, fabricantes e processadores, manipuladores de alimentos e consumidores têm, hoje, a responsabilidade de garantir que o alimento seja seguro e adequado para consumo (Codex, 2010).

Os países importadores e exportadores demonstram interesse na tecnologia de irradiação e vêm desenvolvendo cada vez mais pesquisas para poder cumprir os elevados padrões de qualidade e de quarentena, a fim de ultrapassar fronteiras. A incapacidade de alguns países em satisfazer os regulamentos de quarentena e de saúde pública acarreta obstáculos para o comércio internacional, pois, nem todos os países permitem a importação, por exemplo, de frutas tratadas quimicamente, e alguns proibiram o uso de fumigantes. A aplicação da irradiação oferece uma alternativa à fumigação e a outros tratamentos (CGEE, 2010).

Dentre os países que possuem legislação autorizando o uso da radiação em alimentos, pode-se citar: África do Sul, Alemanha, Arábia Saudita, Argélia, Argentina, Austrália, Áustria, Bangladesh, Bélgica, Brasil, Bulgária, Canadá, Chile, China, Coréia do Sul, Colômbia, Costa Rica, Croácia, Cuba, Dinamarca, Egito, Espanha, Estônia, EUA, Federação Russa, Filipinas, Finlândia, França, Gana, Grécia, Holanda, Hungria, Índia, Indonésia, Irã, Irlanda, Israel, Itália, Japão, Líbia, Luxemburgo, México, Nigéria, Noruega, Paraguai, Peru, Polônia, Portugal, Reino 
Unido, República Checa, Romênia, Sérvia e Montenegro, Síria, Suécia, Tailândia, Tunísia, Turquia, Ucrânia, Uruguai, Venezuela, Vietnã e Zâmbia (IAEA, 2012b).

A TAB.2 apresenta um histórico dos progressos internacionais para a legalização da irradiação de alimentos.

TABELA 2 - Histórico do progresso da irradiação de alimentos no mundo

\begin{tabular}{l|l}
\hline Ano & \multicolumn{1}{c}{ Evento } \\
\hline 1905 & $\begin{array}{l}\text { Concedida patente para um processo de preservação de alimentos } \\
\text { que utiliza radiação ionizante para matar bactérias em alimentos. }\end{array}$ \\
\hline 1921 & $\begin{array}{l}\text { É concedida, nos Estados Unidos, uma patente para o processo que } \\
\text { mataria Trichinella spiral em carnes, utilizando tecnologia de raios-x. }\end{array}$ \\
\hline 1930 & $\begin{array}{l}\text { É concedida, na França, a patente para irradiação de todos os tipos } \\
\text { de alimentos embalados em caixas de metal. }\end{array}$ \\
\hline 1943 & $\begin{array}{l}\text { É concedida permissão para trabalhar na irradiação de pacotes de } \\
\text { alimentos militares (carne de hambúrguer), nos EUA. }\end{array}$ \\
\hline 1947 & $\begin{array}{l}\text { Brasch e Huber publicam relatório sobre preservação e esterilização } \\
\text { de alimentos crus através de elétrons acelerados. }\end{array}$ \\
\hline $1950-51$ & $\begin{array}{l}\text { Governo americano oferece apoio financeiro, a várias Universidades } \\
\text { para facilitar a investigação no estudo da irradiação de alimentos. }\end{array}$ \\
\hline 1958 & $\begin{array}{l}\text { A Produção de dispositivos de radiação gama é iniciada para fins } \\
\text { comerciais. }\end{array}$ \\
\hline $1958-59$ & $\begin{array}{l}\text { A irradiação e o consumo de produtos irradiados foram permitidos na } \\
\text { União Soviética para evitar a germinação de batatas e infestação de } \\
\text { grãos. }\end{array}$ \\
\hline $1963-64$ & $\begin{array}{l}\text { O FDA aprova a irradiação de produtos derivados do trigo para evitar } \\
\text { a infestação e também para inibir germinação de batatas. } \\
\text { O progresso geral foi alcançado após 1980, pois a FAO e a IAEA } \\
\text { declararam que não há risco em consumir alimentos irradiados até } \\
10 \text { kGy. }\end{array}$ \\
\hline $\begin{array}{l}\text { Publicado o Codex Alimentarius e após isto, muitos países } \\
\text { aprovaram normas para a irradiação de alimentos. }\end{array}$ \\
\hline 1980
\end{tabular}


(continuação)

TABELA 2 - Histórico do progresso da irradiação de alimentos no mundo

\begin{tabular}{l|l}
\hline Ano & \multicolumn{1}{|c}{ Evento } \\
\hline 1997 & $\begin{array}{l}\text { Os EUA reconhecem o método de irradiação como método } \\
\text { alternativo para o controle de quarentena. }\end{array}$ \\
\hline 1999 & $\begin{array}{l}\text { A Turquia publicou o Regulamento Irradiação de Alimentos e } \\
\text { aprovou a irradiação de alimentos. }\end{array}$ \\
\hline 2003 & $\begin{array}{l}\text { Codex Alimentarius reconhece que o limite de 10 kGy pode ser } \\
\text { ultrapassado quando exigido. }\end{array}$ \\
\hline 2005 & $\begin{array}{l}\text { A irradiação foi começou a ser utilizado para fins quarentenários em } \\
\text { diversos países. }\end{array}$ \\
\hline
\end{tabular}

Fonte - Alkan \& Yalçintas, 2010.

Para um processo com estas características e vantagens, as oportunidades do seu uso são indubitavelmente promissoras, já que, de acordo com o Centro de Gestão de Estudos Estratégicos (CGEE), calcula-se que anualmente são irradiadas e vendidas 700 mil toneladas de alimentos no mundo; entretanto, é de fundamental importância considerar os principais fatores que fundamentam a instalação de uma unidade de irradiação de alimentos nas cadeias produtivas do agronegócio. (CGEE, 2010).

A World Health Organization (WHO) e a Food and Agricultural Organization (FAO) apoiam esta técnica como forma eficaz e eficiente de conservação de alimentos, especialmente no terceiro mundo, onde se estima que existem perdas entre $30 \%$ a $50 \%$ dos produtos colhidos porque estão infestados e infectados, tornando-se impróprios para o consumo. No Brasil, calcula-se que as perdas de frutas podem chegar a $30 \%$ e que, se aplicada à irradiação, pode-se diminuir, em parte, estas perdas. (CGEE, 2010).

A Food and Agricultural Organization (FAO) estima que a perda póscolheita mundial varia de 15 a $50 \%$, não só devido à colheita fora da época correta, excesso de chuva, de seca ou de extremos de temperatura, 
contaminação por microrganismos, danos físicos e degradação do alimento, mas também por não atender a rígidos controles de qualidade de supermercados, com relação a tamanhos, existência de manchas, formato desigual, entre outros (FAO, 2011).

Com o crescimento da população mundial, o alimento precisará ser transportado a distâncias cada vez maiores, necessitando de esforços, especialmente na infraestrutura de armazenamento e processamento para reduzir a perda ao longo das cadeias produtivas dos agronegócios.

A TAB.3 indica a vida útil de alimentos irradiados e de não irradiados, já que a escolha desta tecnologia permite que se prolongue a vida útil dos alimentos, realizando-se uma melhor distribuição e diminuindo-se os problemas com o abastecimento e as entressafras.

TABELA 3 - Vida útil de alimentos não irradiados e irradiados

\begin{tabular}{l|c|c}
\hline Produto & Vida útil sem irradiação & Vida útil com irradiação \\
\hline Alho & 120 dias & 300 dias \\
\hline Arroz & 365 dias & 1095 dias \\
\hline Banana & 15 dias & 45 dias \\
\hline Batata & 30 dias & 180 dias \\
\hline Cebola & 60 dias & 730 dias \\
\hline Farinha & 180 dias & 18 dias \\
\hline Legumes e Verduras & 5 dias & 21 dias \\
\hline Papaia & 7 dias & 1095 dias \\
\hline Manga & 7 dias & 30 dias \\
\hline Milho & 365 dias & 30 dias \\
\hline Frango refrigerado & 7 dias & 21 dias \\
\hline Filé de pescada refrigerado & 5 dias & 1095 dias \\
\hline Morango & 3 dias & 365 dias \\
\hline Trigo & &
\end{tabular}

Fonte - CENA/USP, 2012. 
Segundo Leonel (2008), a maioria dos consumidores deseja receber esclarecimentos sobre os benefícios do processo de irradiação, sobre a segurança dos alimentos e sobre a segurança da manipulação durante este processo. Os consumidores estão dispostos a comprar e a pagar mais pelos alimentos tratados por métodos chamados alternativos, tornando-os um pedaço do mercado em franca expansão.

A irradiação também possui a vantagem de consumir menor quantidade de energia no processo de tratamento dos alimentos, se comparado a métodos convencionais (Tébéka \& Hallwass, 2007).

Segundo Henson (1995), as associações negativas que os consumidores têm com a irradiação de alimentos restringiram a generalizada implementação da tecnologia. A indústria hesita em adotá-la, preocupada com a opinião do público consumidor, já que exige investimento significativo em infraestrutura. Segundo Polhman et al. (1994) e Hashim et al. (1996), várias pesquisas vêm sendo realizadas para estudar a influência da informação sobre esta tecnologia, o nível de conhecimento e a aceitabilidade dos produtos irradiados.

Segundo Bruhn \& Schutz (1989), com informações científicas, uma maior proporção de consumidores tenderá a adquirir e preferir os alimentos irradiados. Marcotte (1992) e Pszczola (1992; 1993) afirmam que, caso os consumidores percebam os benefícios, eles preferirão os alimentos irradiados; Bruhn (1995b) considera que os estudos sobre atitudes e testes de compra de alimentos irradiados demonstram que os consumidores os aceitam quando têm essa opção, mas seus conhecimentos sobre essa tecnologia são limitados.

\section{4 - A irradiação de alimentos no Brasil}

No Brasil, os estudos sobre a irradiação de alimentos se restringiam quase que exclusivamente às Instituições de Pesquisa, uma vez que o país contava com um número restrito de especialistas. As primeiras pesquisas foram feitas na década de 50, no Centro de Energia Nuclear na Agricultura (CENA). 
- O Decreto-Lei no 986, de 21 de outubro de 1969, instituiu normas básicas sobre alimentos, escrevendo que o alimento irradiado é aquele que foi submetido, intencionalmente, à ação de radiações ionizantes, tendo como finalidade sua preservação ou outros fins lícitos, quando obedecidas as normas que vierem a ser elaboradas pelo órgão competente do Ministério da Saúde (Brasil, 1969).

- O Decreto-Lei oㅜ 72718, em 29 de agosto de 1973, estabelece e regulamenta normas gerais sobre irradiação de alimentos desde a sua elaboração, armazenamento, transporte, distribuição, exportação e exposição à venda ou entrega ao consumidor. Referencia também o registro de equipamentos destinados às operações de irradiação, as condições de funcionamento, os requeridos processos e estabelece que os alimentos irradiados devam fazer constar, em sua embalagem, que foram submetidos a esse processo (Brasil, 1973).

- As Portarias DINAL, complementares, foram editadas em 1985 e 1989. As Portarias oㅡ 09, de 08 de março de 1985 e a no 30, de 25 de setembro de 1989, indicam uma lista de produtos aprovados para irradiação e suas respectivas doses, determinando como dose limite 10 kGy e proibindo a re-irradiação. (Brasil, 1985; 1989)

Atualmente, a irradiação de alimentos é regida pelas normas descritas na Resolução RDC oㅜ 21, de 26 de janeiro de 2001, da ANVISA - Agência Nacional de Vigilância Sanitária (Brasil, 2001), segundo as quais qualquer alimento pode ser irradiado, desde que sejam observados os limites mínimos e máximos da dosagem aplicada, sendo que a dose mínima deve ser suficiente para alcançar a finalidade pretendida e a máxima, inferior àquela que comprometeria as propriedades funcionais e /ou atributos sensoriais do alimento, e pela Instrução Normativa no 9, de 24 de fevereiro de 2011, do MAPA Ministério da Agricultura, Pecuária e Abastecimento, que reconhece o uso da radiação ionizante como tratamento fitossanitário, cujo objetivo é prevenir a introdução ou disseminação de pragas quarentenárias, ou seja, aquelas que têm 
impacto nas exportações e importações (Brasil, 2011).

A técnica de irradiação surge como uma alternativa segura no processo de redução dos microrganismos patogênicos e vem sendo empregada em diversos produtos alimentícios para este fim e para o aumento do tempo de vida de prateleira, já que proporciona a diminuição da contaminação a níveis aceitáveis pela legislação brasileira. A irradiação de alimentos pode ser uma saída para aliviar muito dos problemas de perdas alimentares no mundo e, especificamente, no Brasil. Além disso, esta tecnologia está disponível e seu custo permite o seu uso em escala comercial (Farkas, 2006).

Apesar dos benefícios advindos da irradiação para a segurança dos alimentos, grande parte da população consumidora ainda permanece temerosa, devido à falta de conhecimento sobre a irradiação e seus benefícios. O uso desse processo é limitado pelo alto custo das instalações e pela falta de divulgação, subsidiada por estudos e pesquisas ao consumidor. Os consumidores precisam estar seguros de que os alimentos irradiados são seguros e inócuos (CGEE, 2010).

No aspecto financeiro, a utilização da radiação toma-se economicamente viável, tanto no que se refere ao custo da operação, quanto à durabilidade de produtos perecíveis, pois aumenta a vida útil de produtos armazenados, dando ao produtor a opção de comercializá-los após o período de pico da safra, conseguindo, assim, preços melhores (ICGFI, 1999b; Rela et al, 2005).

Segundo o CGEE (2010) entre os obstáculos que se tem, no Brasil, para a expansão do uso da tecnologia da irradiação, podem-se destacar:

- número muito pequeno de empresas para a prestação de serviços de irradiação de alimentos e embalagens;

- nível de capacidade para investimentos de muitos agronegócios brasileiros muito baixo;

- várias dificuldades para o financiamento da construção das 
instalações para a irradiação;

- dificuldades dos derivados do transporte, dos centros de produção até empresas que prestam serviços de irradiação e seu custo;

- o perfil dos agronegócios e de boa parte das cadeias do agronegócio é constituído por muitas empresas de pequeno e médio porte, que, em tese, tem dificuldades para implantar inovações tecnológicas em seus processos de produção;

- o provável custo adicional da aplicação da irradiação.

De modo geral, o uso da irradiação se justifica pelos benefícios que podem ser alcançados nos agronegócios brasileiros como a redução das perdas pós-colheita ocasionadas pelo amadurecimento, germinação ou crescimento prematuro; a desinfecção de vegetais frescos e produtos armazenados, aumentando o prazo de validade; a redução dos microrganismos responsáveis pela deterioração e a redução do risco de doenças de origem alimentar, mediante a destruição de microrganismos patogênicos (CGEE, 2010).

De qualquer maneira, o caminho para o aproveitamento da aplicação de radiação ionizante para os alimentos e, em decorrência, para as frutas, frutos e derivados processados, está aberto. Portanto, o fato de ser uma tecnologia limpa e, sob o ponto de vista de desempenho, $100 \%$ eficaz nas suas inúmeras aplicações dentro da cadeia produtiva das frutas, abre as portas para a irradiação, de maneira a dar suporte para expansão de seu uso (CGEE, 2010).

Segundo Freitas et al. (2009), como os alimentos são um elemento importante na nossa balança comercial, a escolha por esta tecnologia envolve também a questão financeira, pois, é preciso que se prolongue a vida útil desse alimento, facilitando o seu manejo e barateando o custo final ao consumidor, realizando-se uma distribuição uniforme de alimentos e diminuindo-se os problemas de abastecimento e safra irregulares.

O uso da tecnologia de irradiação de alimentos melhoraria as relações econômicas do país, pois, com a crescente demanda por alimentos mais seguros, iríamos atender ás exigências para importações, aumentando a nossa 
competitividade no mercado externo e o lucro dos nossos exportadores (Leal 2005).

\section{5 - As pesquisas sobre a irradiação de alimentos}

Segundo Ford \& Rennie (1987), após o acidente nuclear de Chernobyl, foi feita, em Manchester, Inglaterra, uma pesquisa com 198 consumidores, sobre a disposição de compra de alimentos irradiados. A pesquisa constatou que apenas $12 \%$ estavam dispostos a comprar os alimentos irradiados contra $70 \%$ que não comprariam; a razão predominante foram os riscos à saúde, incluindo o câncer.

Curzio et al. (1986) e Curzio \& Croci (1990), verificaram que os primeiros produtos irradiados vendidos em um supermercado de Buenos Aires, Argentina, foram o alho e a cebola. Durante três dias de comercialização foram vendidas 10 toneladas de produtos irradiados, o que demonstrou a aceitação do consumidor.

Em 1992, num mercado da Flórida, foi vendido um número recorde de morangos irradiados. No primeiro dia, foram vendidas 600 embalagens, a US $\$$ 2,00 cada, com morangos irradiados, contra 450 embalagens, a US $\$ 1,29$, com morangos não irradiados (Marcotte, 1992).

Segundo Pohlman et al. (1994), a Universidade de Pordue, no estado da Indiana, EUA, fez um documentário sobre a intenção de compra de alimentos irradiados com 89 residentes e constatou-se que, após assistirem a um filme explicativo, The Future of Food Preservation, Food Irradiation, de 8 minutos, houve uma alteração positiva no conhecimento e na intenção de compra de alimentos irradiados, que aumentou para $90 \%$; mas um estudo realizado, com consumidores dos EUA, mostrou que $72 \%$ dos consumidores tinham conhecimento sobre o processo de irradiação, ao mesmo tempo em que $87,5 \%$ deles não conheciam muito do assunto e, de acordo com Resurreccion, Galvez, Fletcher, \& Misra (1995), o conhecimento dos consumidores sobre irradiação de alimentos se mostra inadequado. 
Nos EUA, quando os consumidores são especialmente questionados sobre a segurança alimentar, $82 \%$ deles se preocupam com a contaminação por germes e bactérias e a classificam como um sério problema. No final de 1980, quando questionados sobre a irradiação de alimentos, $43 \%$ dos entrevistados a consideram um risco à saúde; mas, em 1997, esse número caiu para $33 \%$. A irradiação não foi um problema para apenas $20 \%$ dos entrevistados (Bruhn, 1995a).

De acordo com Bruhn (1995a), apesar de o conhecimento científico estar atingindo os consumidores de países considerados desenvolvidos, como os E.U.A., o conhecimento público sobre a irradiação de alimentos é muito pequeno em outros países.

Em março de 1992, um supermercado de Chicago vendeu 172 embalagens de morangos irradiados contra 6 embalagens dos não irradiados, e ambos custavam o mesmo preço. Isso ocorreu após os clientes receberem informações sobre o processo de irradiação. No ano seguinte, os produtos, como tomates, cogumelos e cebolas irradiadas continuaram a vender mais que os não irradiados. Suco de laranja irradiado, por exemplo, foi vendido na proporção de 9 para 1 do não irradiado (ICGFI, 1999a).

Uma pesquisa realizada no Estado do Kansas, EUA, apontou que o preço do alimento irradiado, quando fixado em $10 \%$ menor que o preço do não irradiado, tem uma aceitação de 63\%; quando o preço de ambos é igual, a aceitação é de $47 \%$ e a aceitação é de $17 \%$ quando o preço do alimento irradiado é de $10 \%$ a $20 \%$ mais caro que o alimento não irradiado. Embora a experiência feita tenha sido positiva, os pesquisadores verificaram que os consumidores não estavam plenamente conscientes dos benefícios da irradiação, pois poucos pegaram o material didático informativo disponível no supermercado (ICGFI, 1999a).

Segundo Chen (1992) a aceitação de alimentos irradiados na cidade de Xangai, na China, também foi alta após os consumidores terem recebido um folheto explicativo sobre o processo de irradiação de alimentos, neste caso, $84 \%$ 
dos consumidores disseram aceitar os alimentos irradiados. Entre 1990 e 1995 mais de 30 mil toneladas de alimentos irradiados foram comercializados no país; dentre eles, estão incluídos vegetais desidratados, especiarias e temperos, arroz, cebola, batata, alho, produtos à base de carne, tomate, maçã, entre outros.

$\mathrm{Na}$ cidade de Lyon, na França, foram oferecidas duas toneladas de morangos irradiados aos consumidores acondicionados em bandejas plásticas, etiquetadas com a informação "PROTEGIDAS POR RADIAÇÃO IONIZANTE", e com preço $30 \%$ maior que o do morango não irradiado. A pesquisa realizada mostrou que o produto vendeu muito bem, embora o preço estivesse muito alto para uma comercialização em longo prazo (Laizier, 1987).

Em 1997, Fox \& Olson (1998), realizaram uma pesquisa com 98 membros de 250 famílias, recrutados para participar de um projeto de mercado consumidor. Os consumidores foram convidados a ler as informações do United States Department of Agriculture (USDA), sobre a irradiação de alimentos e a eles foram oferecidos pacotes de peito de frango irradiados e não irradiados. Os participantes tiveram que indicar sua preferência. Quando os preços dos dois produtos eram iguais, $80 \%$ dos participantes indicaram sua preferência pelo frango irradiado; quando o preço do frango irradiado tinha $10 \%$ de desconto, $84 \%$ preferiram e quando o frango irradiado foi oferecido com um preço $10 \%$ superior, apenas $35 \%$ optaram pelo frango irradiado.

Segundo Terry \& Tabor (1998), análises econômicas indicam que o preço influencia na intenção de compra. Nessas análises, os grupos em que a renda era menor, foram sensíveis ao preço, mas, mais da metade das pessoas com renda maior foram propensos a comprar alimentos irradiados com menor, igual ou preço mais elevado do que os preços dos alimentos não irradiados.

De acordo com Crowley et al. (2002), existe uma ligação positiva entre ter consciência sobre esse assunto e a predisposição para comprar os alimentos irradiados. A pesquisa de opinião, feita pelos autores, apresentou que $85 \%$ dos consumidores já tinham ouvido falar em irradiação de alimentos e que $70 \%$ dos consumidores demonstraram a intenção de comprar esses alimentos. A questão 
sanitária foi a que mais apareceu nas justificativas positivas, ou seja, os estudos e testes demonstraram que, quando os consumidores recebem esclarecimentos sobre os benefícios e os riscos à saúde, eles aceitam os alimentos irradiados.

Fox (2002), afirma que os consumidores são expostos a informações desfavoráveis sobre a irradiação de alimentos feita pelos adversários dessa tecnologia. Quanto à demografia, uma infeliz e importante consequência é que as crianças, um grupo mais suscetível a doenças transmitidas por alimentos, parecem ser as que menos vão se beneficiar com a disponibilidade de alimentos irradiados, pois suas mães estão menos convencidas sobre a sua segurança. Em relação aos rótulos dos produtos, constata que o que realmente faz diferença é a eficácia da tecnologia, pois, quando questionados se preferiam o método da pasteurização, cuja eficácia é de $99 \%$ ou o da irradiação, cuja eficácia é de 100\%, $62 \%$ dos consumidores preferiram a irradiação, o que significa que a escolha parece ser mais influenciada pela segurança alimentar do que pelos nomes que aparecem nos rótulos.

Os alimentos irradiados são bem recebidos pelos consumidores, nos EUA, já que esse tipo de tratamento é eficiente quando se deseja aumentar a segurança dos alimentos, pois reduz o número de microrganismos presentes nos alimentos e diminui os prejuízos econômicos e sociais, diminuindo as perdas causadas pelas ações dos microrganismos e o número de doenças transmitidas através dos alimentos (Santos et al., 2003).

Em Istambul, onde vivem 15\% da população da Turquia, foi realizada uma pesquisa por Gunes \& Tekin (2006). A amostra utilizada na pesquisa foi composta por 31 funcionários e clientes de um grande supermercado, 20 funcionários de uma escola privada, 27 funcionários de um banco, 32 funcionários do correio, 156 funcionários e clientes de um aeroporto, 34 funcionários e clientes de um salão de beleza e 144 estudantes de uma universidade em Istambul. No total, foram obtidas 444 respostas, sendo $42 \%$ de consumidores do gênero masculino e $58 \%$ de consumidores do gênero feminino. Entre os homens, $79 \%$ tinham menos de 40 anos e apenas $1 \%$ tinha mais de 60 anos de idade. 
A amostra de consumidores revelou diferentes níveis de renda:

- $45 \%$ dos consumidores possuíam baixa renda (até 0,5 bilhões de liras turcas) (até $\mathrm{R} \$ 837,00$ );

- $51 \%$ tinham média renda (de 0,5 a 2 bilhões de liras turcas) (de $\mathrm{R} \$$ 838,00 até $R \$ 1674,00$ );

- $4 \%$ tinham alta renda (acima de 2 bilhões de liras turcas) (acima de $\mathrm{R} \$ 1675,00)$.

Este trabalho utilizou, em novembro de 2011, a conversão de $\mathrm{R} \$ 1,00=$ TRL 0,837, pois em 2007, a TRL foi dividida por 1.000 .000 , passando a ser chamada de Yene Turk Lirasi (YTL).

Entre os entrevistados, $80 \%$ se mostraram incertos sobre a segurança dos alimentos irradiados, $11 \%$ dos entrevistados se mostraram confiantes na segurança dos irradiados e $9 \%$ indicaram como não seguros; mas, após os esclarecimentos, $29 \%$ dos consumidores disseram ter confiança nos alimentos irradiados. Também, após os esclarecimentos, os consumidores foram questionados sobre a aquisição de alimentos irradiados e $62 \%$ deles disseram que comprariam; $13 \%$ disseram que não comprariam e, $25 \%$ se mostraram indecisos. Gunes \& Tekin (2006) chegaram à conclusão de que a aceitação pode aumentar, mais ainda, se o preço dos alimentos irradiados for igual ao preço dos alimentos não irradiados.

Em 2006, foram realizadas entrevistas com voluntários de 18 a 55 anos que se encontravam na Faculdade de Ciências Farmacêuticas da USP: 48\% disseram que provavelmente comprariam alimentos irradiados e $31 \%$ disseram que, com certeza, comprariam (IPEN, 2010).

Segundo Francisco et al. (2007), caracterizando consumidores de carne de frango, verificaram que, apesar da falta de conhecimento ou de informação, os consumidores estão interessados em obter o máximo de informações a respeito do produto que estão consumindo, principalmente a respeito da sua qualidade, data de validade, registro de inspeção federal, 
certificação e advertência quanto a riscos de intoxicação alimentar. Os consumidores estavam acostumados a "comprar com os olhos", porém, hoje, cada vez mais, exigem informações, qualidade e possuem interesse por novas tecnologias, estando muito mais propensos a comprar alimentos tratados por métodos alternativos e dispostos a pagar a mais por isso, mostrando um nicho do mercado em gradativa expansão.

As pesquisas sugerem que as pessoas tendem a não estarem familiarizados com a irradiação de alimentos, mas a irradiação de alimentos já é permitida internacionalmente, por vários países. Na Europa, é usada em para esterilização de ervas secas, especiarias e condimentos vegetais e, nos EUA, ela é permitida, também, para carnes (Frewer et al., 2011).

\section{6 - As instalações para irradiação de alimentos no Brasil}

Segundo o CGEE (2010), no Brasil, há 5 instituições públicas e privadas que irradiam produtos em escala comercial, o maior volume pertence à área médica e farmacêutica (cosméticos e fitoterápicos); mas embalagens, polímeros, matérias primas nas áreas de desinfestação entre outros, também são irradiados. $\mathrm{Na}$ área alimentar irradiam-se especiarias, frutas frescas e desidratadas e vegetais frescos e desidratados.

- A CBE Embrarad (FIG.8) possui duas unidades de processamento, uma na cidade de Cotia, na Grande São Paulo, que iniciou suas operações em 1980 com um irradiador JS 7500, e em 1999, inaugurou o seu segundo irradiador, um JS 9500, os dois fabricados pela Nordion Ion Tecnologies (Canadá); a outra unidade está instalada na cidade de Jarinu e iniciou suas operações em 1999, com um irradiador de fabricação nacional. A CBE Embrarad processa materiais diversos; o maior volume pertence à área médica e farmacêutica e, na área alimentar, o maior volume é o de especiarias (pimenta, cominho, páprica, entre outros). 


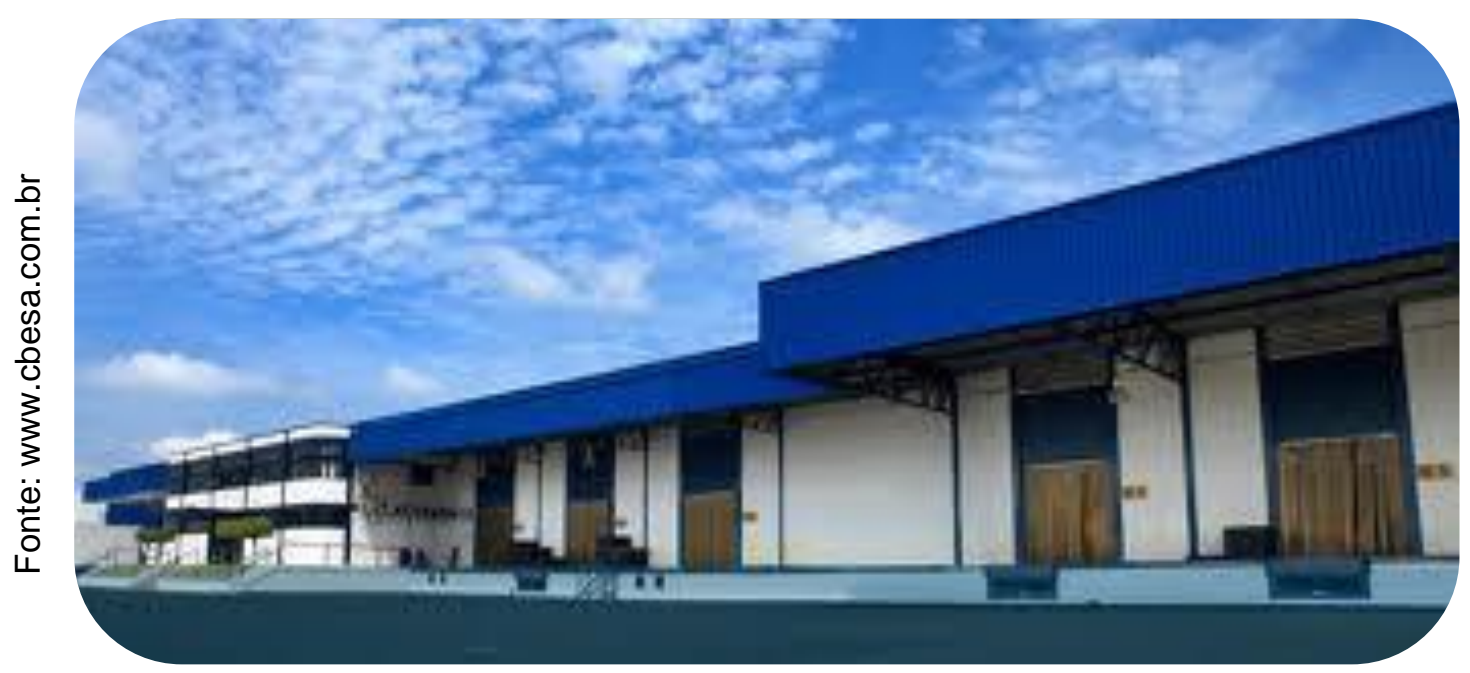

FIGURA 8 - CBE Embrarad

- A Acelétron Irradiação Comercial (FIG.9) está localizada na cidade do Rio de Janeiro, no bairro do Irajá. É a única empresa, na América Latina, a prestar serviços de irradiação industrial, utilizando dois aceleradores de elétrons - Linear Particle Accelerator (LINAC), de $18 \mathrm{kV}$ de potência e $10 \mathrm{MeV}$ de energia cada um. Essa tecnologia utiliza a eletricidade como fonte de energia, não sendo necessário o uso de materiais radioativos. No sistema utilizado pela Acelétron, os produtos embalados são transportados por uma esteira e irradiados, ao passarem pelo feixe de elétrons. A taxa de dose de cada acelerador linear permanece constante. A dose aplicada ao produto pode ser variada, com ajuste na velocidade da esteira transportadora, controlando assim o tempo de exposição do produto ao feixe. O sistema de feixe de elétrons utilizado pela Acelétron é projetado para operar 24 horas por dia, o ano inteiro. A tecnologia de feixe permite a utilização de elétrons para irradiar industrialmente os mais variados produtos $\mathrm{e}$ materiais, como material médico hospitalar, embalagens, cosméticos, fitoterápicos, polímeros e alimentos como especiarias, frutas frescas e desidratadas e vegetais frescos e desidratados, entre outros. 


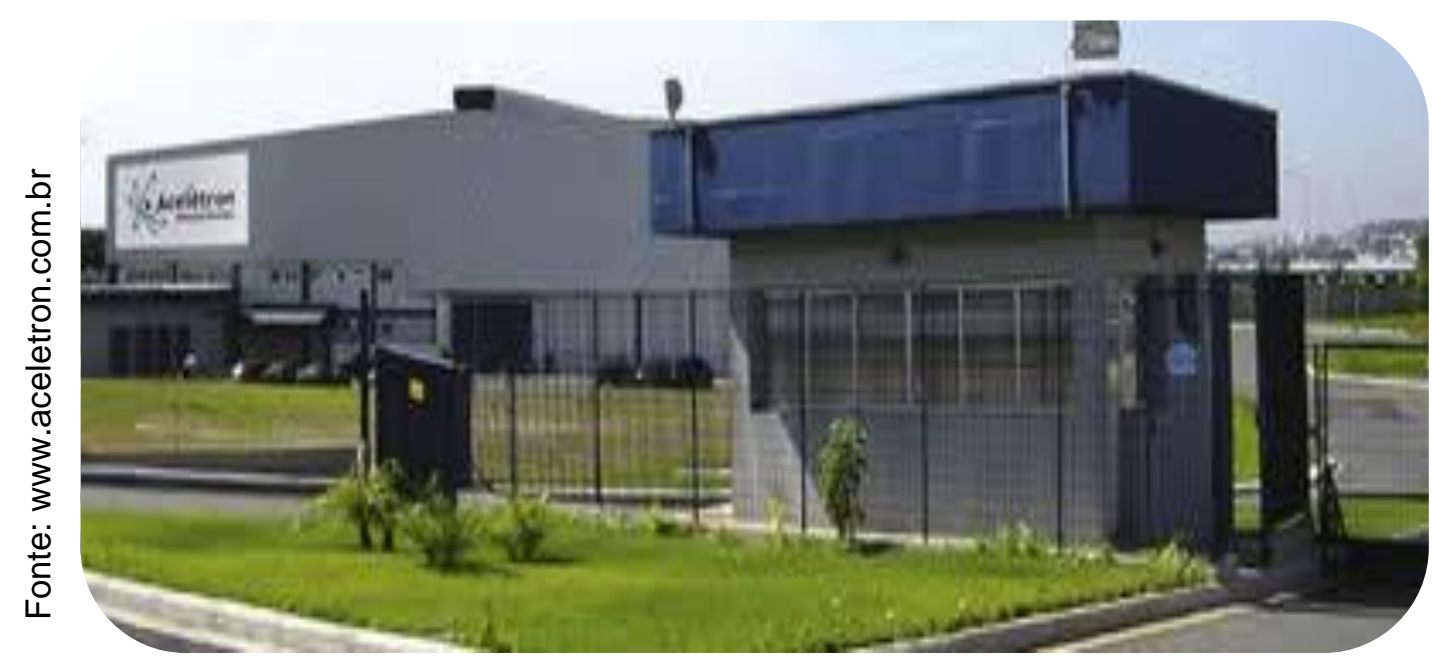

FIGURA 9 - Acelétron Irradiação Comercial

Ainda segundo o CGEE (2010), no Brasil, há 3 Instituições que realizam pesquisas para o desenvolvimento da irradiação de produtos e alimentos.

- O Instituto de Pesquisas Energéticas e Nucleares - IPEN CNEN/USP, (FIG.10), possui um irradiador multipropósitos de Cobalto-60, tipo compacto, no Centro de Tecnologia das Radiações (CTR). É inteiramente nacional e inédito em muitas de suas características técnicas, permitindo o desenvolvimento de lotes adequados para estudos de otimização da produção em escala industrial, validando sistemas dosimétricos e códigos computacionais de mapeamento de doses e transferindo tecnologia para implantação de irradiadores de grande porte no país. Utiliza a radiação gama para processar continuamente os produtos e/ou matérias primas nas áreas de desinfestação e preservação de produtos alimentícios (especiarias, ervas aromáticas liofilizadas, proteínas de origem animal e vegetal, plantas ornamentais, frutas e produtos de aplicação na agricultura como turfa e sementes). Suas características técnicas são: capacidade total, licenciada pela CNEN é de $37 \mathrm{PBq}$ (1 milhão de Curries) e atividade inicial de operação de $3,7 \mathrm{PBq}-100 \mathrm{KCi}$. 


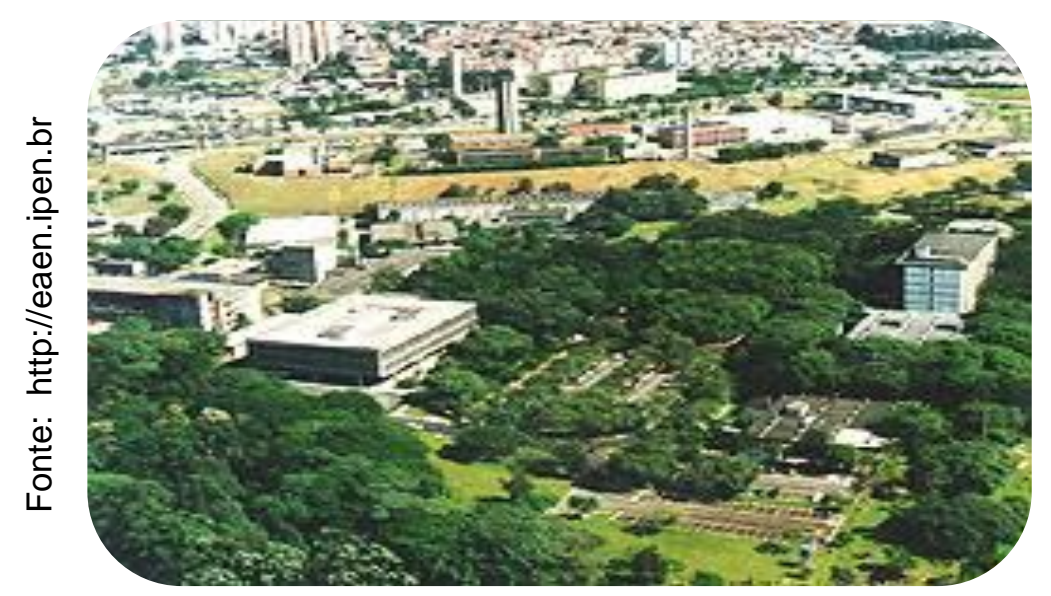

FIGURA 10 - IPEN/USP

- O Centro de Energia Nuclear na Agricultura (CENA/USP), FIG.11, está localizado na cidade de Piracicaba, interior de São Paulo, como Instituto anexo a Escola de Agronomia Luiz de Queiroz (ESALQ/USP). Em seu laboratório de Irradiação e Radioentomologia, presta serviços a unidades da USP e a empresas privadas em relação a análises químicas, físicas, microbiológicas e sensoriais de alimentos; serviços de irradiação gama; ensaios de marcação de pragas com radioisótopos para estudos ecológicos; fornecimento de parasitoides para controle biológico de moscas-das-frutas e consultorias. Atua nas áreas de conservação e higienização de alimentos; tratamento pós-colheita; controle biológico de moscas-das-frutas; na ecologia e comportamento de pragas e no tratamento quarentenário por irradiação.

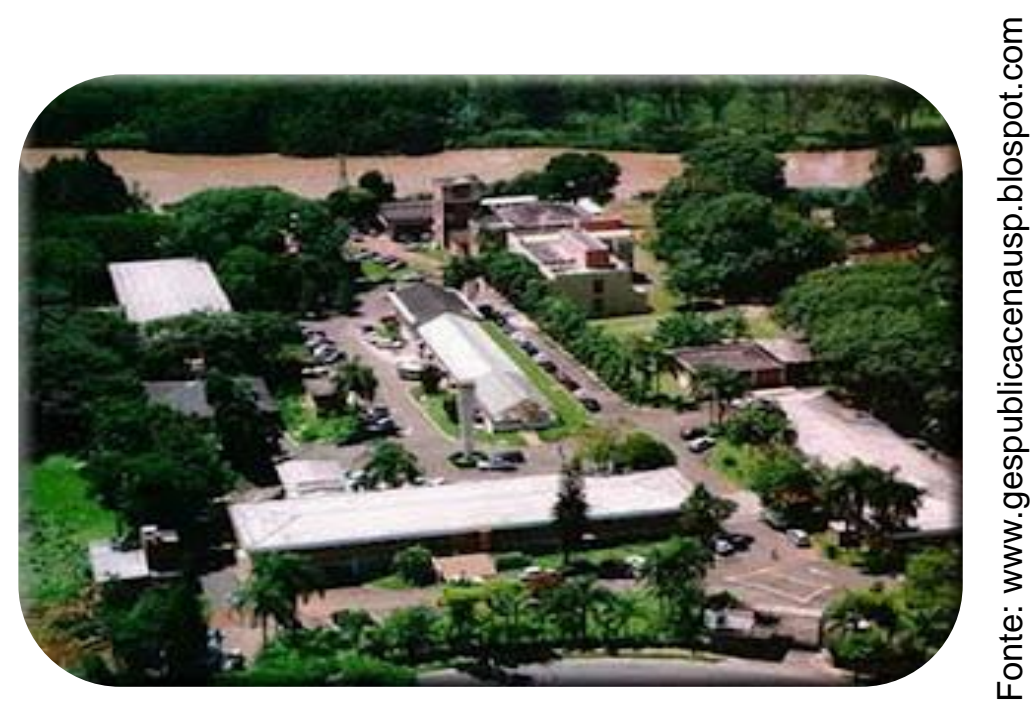


- O Centro Tecnológico do Exército (CTEx), FIG.12, localizado na cidade do Rio de Janeiro, através de sua seção de Defesa Nuclear, Divisão de Defesa Química, Biológica e Nuclear, possui um irradiador gama para pesquisas e tem, para universidades e mesmo empresas, disponibilizando seu equipamento para a área de alimentos, incluindo frutas e tubérculos.

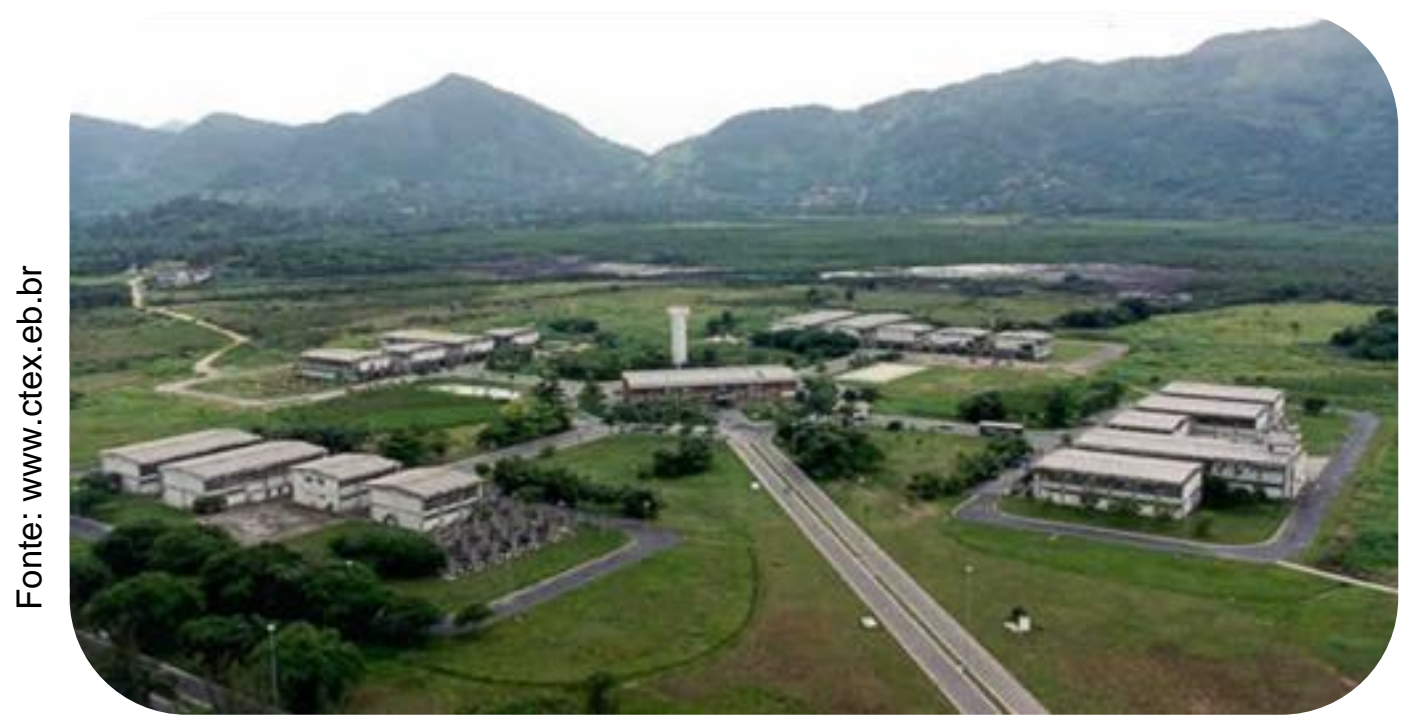

FIGURA 12 - CTEX

\section{7 - As instalações para irradiação de alimentos no mundo}

Atualmente, a irradiação comercial de alimentos é aplicada em cerca de 50 países, utilizando aproximadamente 200 instalações. As instalações, em sua maioria, utilizam o Cobalto $60\left({ }^{60} \mathrm{Co}\right)$ como fonte de irradiação, no entanto, algumas utilizam aceleradores de elétrons (Linear Particle Accelerator).

Anualmente são irradiadas mais de 700 mil toneladas de alimentos em todo mundo, e embora essa quantidade represente apenas uma pequena fração do que é consumido e a tendência do mercado de importação e exportação é crescer e em relação às oportunidades de expansão, à medida que se tenha legislações mais flexíveis quanto ao uso da tecnologia podem-se potencializar as oportunidades para sua aplicação massiva (CGEE, 2010).

A International Atomic Energy Agency (IAEA) possui, atualmente, 154 
países membros, dos quais cerca de 62 possuem algum tipo de regulamentação sobre a irradiação de alimentos, seja para a exportação, pela exigência dos mercados consumidores ou para a importação, para controle de entrada de alimentos no país (IAEA, 2012b).

A TAB.4 indica a quantidade de instalações para irradiação de alimentos existentes na África e na Oceania e os principais tipos de alimentos irradiados por esses países.

TABELA 4 - Quantidade de instalações da África e Oceania e principais alimentos irradiados

\begin{tabular}{|c|c|c|}
\hline PAÍS & $\begin{array}{c}\text { QUANTIDADE DE } \\
\text { INSTALAÇÕES PARA } \\
\text { IRRADIAÇÃO DE } \\
\text { ALIMENTOS }\end{array}$ & $\begin{array}{l}\text { PRINCIPAIS } \\
\text { ALIMENTOS } \\
\text { IRRADIADOS }\end{array}$ \\
\hline ÁFRICA DO SUL & 01 & $\begin{array}{l}\text { especiarias, frutas, } \\
\text { vegetais frescos, mel, } \\
\text { carnes e pescado. }\end{array}$ \\
\hline AUSTRÁLIA ${ }^{a}$ & 04 & $\begin{array}{l}\text { especiarias, grãos e } \\
\text { frutas. }\end{array}$ \\
\hline EGITO & 01 & $\begin{array}{l}\text { especiarias, vegetais, } \\
\text { frutas, aves, carnes e } \\
\text { peixes. }\end{array}$ \\
\hline GANA & 01 & $\begin{array}{l}\text { especiarias, frutas, peixe } \\
\text { e vegetais secos. }\end{array}$ \\
\hline NIGÉRIA & 01 & $\begin{array}{l}\text { especiarias e vegetais } \\
\text { secos. }\end{array}$ \\
\hline
\end{tabular}

a: A Austrália pertence à Oceania

Fonte - CGEE, 2010; IAEA, 2012a.

A TAB.5 indica a quantidade de instalações para irradiação de alimentos existentes nas Américas do Sul, Central e Norte e os principais tipos de alimentos irradiados por esses países. 
TABELA 5 - Quantidade de instalações das Américas e principais alimentos irradiados

\begin{tabular}{|c|c|c|}
\hline PAÍS & $\begin{array}{c}\text { QUANTIDADE DE } \\
\text { INSTALAÇÕES PARA } \\
\text { IRRADIAÇÃO DE } \\
\text { ALIMENTOS }\end{array}$ & $\begin{array}{l}\text { PRINCIPAIS } \\
\text { ALIMENTOS } \\
\text { IRRADIADOS }\end{array}$ \\
\hline ARGENTINA & 02 & $\begin{array}{lr}\text { especiarias, } & \text { vegetais } \\
\text { frescos e } & \text { frutas } \\
\text { desidratadas. } & \end{array}$ \\
\hline BRASIL & 05 & $\begin{array}{ll}\text { especiarias, } & \text { vegetais } \\
\text { frescos, ração animal, } \\
\text { grãos e frutas. }\end{array}$ \\
\hline CANADÁ & 01 & $\begin{array}{l}\text { especiarias e vegetais } \\
\text { secos. }\end{array}$ \\
\hline CHILE & 01 & $\begin{array}{l}\text { especiarias e vegetais } \\
\text { secos. }\end{array}$ \\
\hline COLOMBIA & 01 & $\begin{array}{l}\text { especiarias e vegetais } \\
\text { secos. }\end{array}$ \\
\hline CUBA & 01 & $\begin{array}{l}\text { especiarias e vegetais } \\
\text { secos. }\end{array}$ \\
\hline E.U.A. & 50 & $\begin{array}{l}\text { especiarias, frutas, } \\
\text { carnes, frutos do mar, } \\
\text { ração animal e produtos } \\
\text { processados. }\end{array}$ \\
\hline MÉXICO & 02 & especiarias e frutas. \\
\hline PERU & 01 & $\begin{array}{l}\text { especiarias e vegetais } \\
\text { secos. }\end{array}$ \\
\hline VENEZUELA & 01 & $\begin{array}{l}\text { especiarias e vegetais } \\
\text { secos. }\end{array}$ \\
\hline
\end{tabular}

Fonte - CGEE, 2010; IAEA, 2012a.

A TAB.6 indica a quantidade de instalações para irradiação de alimentos existentes na Ásia e os principais tipos de alimentos irradiados por esses países. 
TABELA 6 - Quantidade de instalações da Ásia e principais alimentos irradiados

\begin{tabular}{|c|c|c|}
\hline PAÍS & $\begin{array}{l}\text { QUANTIDADE DE } \\
\text { INSTALAÇÕES PARA } \\
\text { IRRADIAÇÃO DE } \\
\text { ALIMENTOS }\end{array}$ & $\begin{array}{l}\text { PRINCIPAIS } \\
\text { ALIMENTOS } \\
\text { IRRADIADOS }\end{array}$ \\
\hline ARÁBIA SAUDITA & 01 & $\begin{array}{l}\text { especiarias e vegetais } \\
\text { secos. }\end{array}$ \\
\hline BANGLADESH & 01 & $\begin{array}{l}\text { especiarias, peixes, aves, } \\
\text { frutas e vegetais frescos. }\end{array}$ \\
\hline CHINA & 70 & $\begin{array}{l}\text { especiarias, frutas, } \\
\text { carnes vegetais frescos } \\
\text { e secos. }\end{array}$ \\
\hline CORÉIA DO SUL & 03 & $\begin{array}{l}\text { especiarias e vegetais } \\
\text { secos. }\end{array}$ \\
\hline FILIPINAS & 01 & $\begin{array}{l}\text { especiarias, frutas } \mathrm{e} \\
\text { vegetais desidratados. }\end{array}$ \\
\hline ÍNDIA & 08 & $\begin{array}{l}\text { especiarias, } \\
\text { desidratados e frutas } \\
\text { secas. }\end{array}$ \\
\hline INDONÉSIA & 01 & $\begin{array}{l}\text { especiarias, pernas de } \\
\text { rãs, vegetais secos } \\
\text { peixes, frutas. }\end{array}$ \\
\hline IRÃ & 01 & $\begin{array}{l}\text { especiarias e vegetais } \\
\text { secos. }\end{array}$ \\
\hline ISRAEL & 01 & $\begin{array}{l}\text { especiarias e vegetais } \\
\text { secos. }\end{array}$ \\
\hline SIRIA & 01 & $\begin{array}{l}\text { especiarias e vegetais } \\
\text { secos. }\end{array}$ \\
\hline TAILÂNDIA & 02 & $\begin{array}{l}\text { especiarias, frutas e } \\
\text { vegetais frescos. }\end{array}$ \\
\hline VIETNÃ & 03 & $\begin{array}{l}\text { especiarias, carnes, } \\
\text { frutas e frutos do mar. }\end{array}$ \\
\hline
\end{tabular}

Fonte - CGEE, 2010; IAEA, 2012a. 
A TAB.7 indica a quantidade de instalações para irradiação de alimentos existentes na Europa e os principais tipos de alimentos irradiados por esses países.

TABELA 7 - Quantidade de instalações da Europa e principais alimentos irradiados

\begin{tabular}{|c|c|c|}
\hline PAÍS & $\begin{array}{l}\text { QUANTIDADE DE } \\
\text { INSTALAÇÕES PARA } \\
\text { IRRADIAÇÃO DE } \\
\text { ALIMENTOS }\end{array}$ & $\begin{array}{l}\text { PRINCIPAIS } \\
\text { ALIMENTOS } \\
\text { IRRADIADOS }\end{array}$ \\
\hline ALEMANHA & 05 & $\begin{array}{l}\text { especiarias e vegetais } \\
\text { secos. }\end{array}$ \\
\hline BÉLGICA & 02 & $\begin{array}{l}\text { especiarias, pernas de } \\
\text { rãs, camarão, peixe, } \\
\text { carnes, aves e vegetais } \\
\text { secos. }\end{array}$ \\
\hline BULGÁRIA & 02 & $\begin{array}{l}\text { especiarias e vegetais } \\
\text { secos. }\end{array}$ \\
\hline CROÁCIA & 01 & $\begin{array}{l}\text { especiarias e vegetais } \\
\text { secos. }\end{array}$ \\
\hline ESPANHA & 03 & $\begin{array}{l}\text { especiarias e vegetais } \\
\text { secos. }\end{array}$ \\
\hline ESTÔNIA & 01 & $\begin{array}{l}\text { especiarias e vegetais } \\
\text { secos. }\end{array}$ \\
\hline FRANÇA & 04 & $\begin{array}{l}\text { especiarias, carnes, } \\
\text { frango desossado, } \\
\text { vegetais frescos e secos, } \\
\text { pernas de rãs congeladas } \\
\text { e lagostins. }\end{array}$ \\
\hline HOLANDA & 02 & $\begin{array}{l}\text { especiarias, frutos secos, } \\
\text { camarões, pernas de rãs, } \\
\text { vegetais frescos e } \\
\text { desidratados. }\end{array}$ \\
\hline
\end{tabular}


(continuação)

TABELA 7 - Quantidade de instalações da Europa e principais alimentos irradiados

\begin{tabular}{|c|c|c|}
\hline PAíS & $\begin{array}{l}\text { QUANTIDADE DE } \\
\text { INSTALAÇÕES PARA } \\
\text { IRRADIAÇÃO DE } \\
\text { ALIMENTOS }\end{array}$ & $\begin{array}{l}\text { PRINCIPAIS } \\
\text { ALIMENTOS } \\
\text { IRRADIADOS }\end{array}$ \\
\hline HUNGRIA & 02 & $\begin{array}{l}\text { especiarias e vegetais } \\
\text { frescos. }\end{array}$ \\
\hline ITÁLIA & 01 & $\begin{array}{l}\text { especiarias e vegetais } \\
\text { secos. }\end{array}$ \\
\hline POLÔNIA & 02 & $\begin{array}{l}\text { especiarias, vegetais } \\
\text { frescos e desidratados. }\end{array}$ \\
\hline PORTUGAL & 01 & $\begin{array}{l}\text { especiarias e vegetais } \\
\text { secos. }\end{array}$ \\
\hline REINO UNIDO & 01 & $\begin{array}{lll}\text { especiarias } & \text { e } & \text { ervas } \\
\text { aromáticas. } & & \\
\end{array}$ \\
\hline REPUBLICA CHECA & 01 & $\begin{array}{l}\text { especiarias e vegetais } \\
\text { secos. }\end{array}$ \\
\hline ROMÊNIA & 01 & $\begin{array}{l}\text { especiarias e vegetais } \\
\text { secos. }\end{array}$ \\
\hline $\begin{array}{l}\text { SÉRVIA } \\
\text { MONTENEGRO }\end{array}$ & 01 & $\begin{array}{l}\text { especiarias e vegetais } \\
\text { secos. }\end{array}$ \\
\hline TURQUIA & 02 & $\begin{array}{l}\text { especiarias, vegetais } \\
\text { frescos, frutas frescas, } \\
\text { carnes, aves, pernas de } \\
\text { rãs, frutos do mar e } \\
\text { grãos. }\end{array}$ \\
\hline
\end{tabular}

Fonte - CGEE, 2010; IAEA, 2012a.

\section{8 - Oportunidades para o uso da tecnologia de irradiação}

Segundo o CGEE (2010), a evolução das técnicas de irradiação vem possibilitando a comercialização de produtos altamente perecíveis entre países 
distantes, pois o aperfeiçoamento dos processos de irradiação pode, com segurança e economia, substituir os longos processos de produção e distribuição. Os países importadores de produtos alimentares estão se tornando cada vez mais exigentes em relação aos aspectos fitossanitários, com restrições aos resíduos de pesticidas e infestação de pragas.

Em relação ao aspecto financeiro, o tratamento do alimento por meio da irradiação, aumentando sua vida útil, dá ao produtor a opção de comercializálo fora do período de safra, conseguindo muitas vezes melhores preços (CGEE, 2010).

Os mercados internacionais, para a aplicação da irradiação de alimentos, estão em expansão; vários países já consideram o tratamento por irradiação como uma alternativa tecnológica necessária, possuindo legislações que permitem a importação de alimentos irradiados e o seu controle, mesmo sem possuir instalações para a aplicação da irradiação de seus próprios produtos para exportação. Os avanços ainda dependem de uma legislação mais liberal da União Europeia, autorizando que mais produtos alimentares, como frutas e derivados, sejam tratados por irradiação (IAEA, 2010a).

O Brasil apresenta uma grande diversificação climática e possui centros de produção agropecuária em regiões tropicais e equatoriais, o que proporciona uma gama ímpar de alimentos para a exportação. Muitas pesquisas estão sendo realizadas na busca de processos que garantam a segurança, as características sensoriais e o valor nutricional dos produtos processados do agronegócio, além da tentativa de reduzir seus custos. Por outro lado, também se verifica que os consumidores, além de buscarem benefícios, podem associar uma tecnologia ou método de processamento como um importante fator na avaliação do risco potencial no momento da decisão de compra das frutas processadas e outros produtos agro industrializados (CGEE, 2010).

O CGEE (2010) realizou um levantamento junto às empresas processadoras e, de acordo com os empresários, a utilização desse processo é limitada pelo alto custo das instalações, de US\$ 3 a US\$ 5 milhões, e apesar de 
considerarem a tecnologia segura, não se sentem estimulados por terem conhecimento da baixa aceitabilidade de tecnologia por parte dos consumidores.

A aceitação e a satisfação dos mais exigentes consumidores necessitam de uma solução particular para cada problema de conservação e neste caso, a irradiação pode contribuir como uma ferramenta interessante para evitar a grande incidência das Doenças Transmitidas por Alimentos (DTA) e as milionárias perdas de frutas, vegetais, grãos, etc., que ocorrem a cada ano no Brasil e no exterior (FAO, 2011).

A irradiação proporciona importantes benefícios para a saúde e para o meio ambiente; esses podem ser os principais motivos para a oportunidade de uma utilização maior da tecnologia de irradiação dos produtos gerados pelo agronegócio, com fins alimentares ou não, que poderão aumentar ainda mais nos próximos anos, isto é, o mercado nacional como um todo é um mercado em expansão, devendo dobrar num horizonte de 10 anos (CGEE, 2010).

\section{9 - Viabilidade econômica}

Segundo Rozenfeld et al. (2006), o Estudo de Viabilidade Econômica está muitas vezes vinculado à elaboração de um plano de negócio e é geralmente aplicado em empresas que apresentam uma estrutura de funcionamento consolidada, que demonstram interesse em investir em novos ramos do mercado ou em infraestrutura. Seu objetivo é o de identificar o melhor momento, além da própria viabilidade, para a aplicação dos recursos planejados. Dessa forma, o Estudo de Viabilidade Econômica abrange etapas referentes às análises sobre o mercado, com a posterior projeção de faturamento para o cálculo de indicadores que mensurarão a viabilidade do empreendimento.

As atividades econômicas realizadas envolvem um risco: podem dar certo, conduzindo ao objetivo previsto ou podem dar errado. O estudo de viabilidade é a análise detalhada, que tem dois objetivos básicos:

- identificar e fortalecer as condições necessárias para o projeto dar 
certo;

- identificar e tentar neutralizar os fatores que podem dificultar as possibilidades de êxito do projeto.

O estudo de viabilidade indica as condições para que os objetivos propostos dependam mais de ações do que da sorte e deve ser feito antes de se iniciar a atividade (Rozenfeld et al., 2006).

O processo de produção precisa ser objetivo, ter informações sobre a quantidade que vai ser produzida, quais as matérias primas que teremos que comprar e quanto custam. Qual é o equipamento que deve ser comprado, qual a instalação necessária, qual o tipo de energia vai ser consumida e se essa quantidade é consumida por hora ou por quantidade produzida (Rozenfeld et al., 2006).

A comercialização também é um problema que precisa ser enfrentado; antes do início do projeto, é preciso ter um mínimo de segurança sobre a venda da produção e se essa venda vai ser realizada por um preço que seja suficiente para suplantar todos os custos, inclusive os fiscais (Rozenfeld et al., 2006).

O principal elemento que justifica a existência de uma empresa é a geração de lucro. Para os investidores, porém, não basta que o projeto tenha um resultado positivo. Para um projeto de desenvolvimento ser atrativo, é preciso que a quantidade de lucro gerado, o retorno do projeto, seja melhor do que aquele que a empresa poderia obter com outros investimentos, por exemplo, aplicando no mercado financeiro, portanto, a essência da avaliação econômico-financeira é medir o retorno do projeto de maneira comparável com outros investimentos (Motta \& Calôba, 2002).

Uma das primeiras pessoas a analisar o custo-benefício de obras públicas foi Arsene-Jules-Emile Juvenal Dupuit (1804-1866) em 1844, mas, segundo Hufschmidt et al. (1983), em 1936, para atender um requerimento do governo federal americano, as análises de custo-benefício foram implantadas 
também para recursos hídricos e, a partir de 1950, o uso dessa técnica se popularizou em todo o mundo.

A regra formal da viabilidade na análise do custo (C) - benefício (B) é descrita por B - C > 0, mas Pearce (1990) propõe a inserção de uma variável ambiental $(A)$, porque acredita que os custos ambientais também devam ser considerados, logo se tem a equação (1):

$$
\mathrm{B}-\mathrm{C}-\mathrm{A}>0
$$

Este conceito de variável ambiental apresenta algumas dificuldades operacionais, pois os custos ambientais podem ser estabelecidos de maneira subjetiva, já que a sua valorização, em termos econômicos, nem sempre está claramente estabelecida.

$\mathrm{Na}$ análise econômica, o termo custo representa a compensação financeira que os produtores devem receber para que continuem fornecendo ao sistema que irá beneficiar o alimento. Os custos são classificados em fixos, quando não se alteram de acordo com a quantidade produzida e variáveis quando dependem do nível de produção. Existe ainda a depreciação, que é o custo necessário para substituir os bens de capital de longa duração, quando estes perdem sua vida útil, em consequência do desgaste físico e do valor que perdem com o passar do tempo, devido às inovações tecnológicas ou à capacidade de gerar receitas (Frizzone, 1999).

$\mathrm{Na}$ análise custo-benefício, são definidos os principais indicadores financeiros do projeto, relacionados com o produto final, tais como as previsões de retorno do investimento e a análise de suas características, o Fluxo de Caixa (FC), o Valor Presente Líquido (VPL), a Taxa Interna de Retorno (TIR) e o Tempo de Retorno do Investimento (TRI) ou Método do Payback (Motta \& Calôba, 2002).

\subsection{1 - Fluxo de Caixa (FC)}

De acordo com Martinovich (1996), Fluxo de Caixa (FC) é um 
instrumento gerencial fundamental na tomada de decisões empresariais. Seus objetivos são a coleta e a organização dos dados e a geração de subsídios, para a análise de desempenho financeiro e para a realização de previsões orçamentárias, pois, para sabermos se um projeto é viável ou não economicamente, precisamos avaliar e comparar o fluxo com outros investimentos à disposição. Nesse cálculo, deve-se levar em consideração que o dinheiro possui um valor dependente do tempo, isto é, receber hoje é diferente do que receber o mesmo valor no próximo ano, portanto, utilizam-se índices financeiros e parâmetros, calculados com os dados do Fluxo de Caixa (FC), que permitem comparações e análises do desempenho financeiro do projeto.

\subsection{2 - Valor Presente Líquido (VPL)}

Segundo Motta \& Calôba (2002) a definição de Valor Presente Líquido (VPL) é a de uma soma algébrica de fluxos de caixa descontados para o instante presente, a uma taxa de juros $\mathrm{i}$, isto é, um método para análise de investimentos que determina o valor presente de pagamentos futuros e consiste em uma fórmula matemático-financeira em que o valor dos investimentos e do fluxo de caixa atual e futuro são convertidos para um valor equivalente, na data atual, por meio de uma taxa de conversão devida ao fato do poder aquisitivo do dinheiro sofrer alterações com o passar do tempo.

O Valor Presente Líquido é calculado por meio da equação 2:

$$
V P L=\sum_{t=0}^{n} \frac{F C_{t}}{(1+i)^{t}}
$$

na qual:

$\mathrm{t}=$ período (anos ou meses);

$\mathrm{n}=$ tempo total do projeto (anos ou meses);

$\mathrm{i}$ = Taxa Mínima de Atratividade (TMA);

FC = Fluxo de Caixa por período. 
A taxa de conversão (i) utilizada neste método é a Taxa Mínima de Atratividade (TMA), que é a taxa mínima de retorno que o investidor pretende conseguir como rendimento, ao realizar o investimento. Pode ser entendida como o retorno que o investidor espera pelo capital que está empregando em determinado investimento, traduzido a uma taxa percentual sobre o próprio investimento, por um determinado espaço de tempo.

O Valor Presente Líquido (VPL) de um projeto de investimento possui as seguintes possibilidades de resultado:

- Maior do que zero: significa que o investimento é economicamente atrativo, pois o valor presente das entradas de caixa é maior do que o valor presente das saídas de caixa.

- Igual a zero: o investimento é indiferente, pois o valor presente das entradas de caixa é igual ao valor presente das saídas de caixa.

- Menor do que zero: indica que o investimento não é economicamente atrativo porque o valor presente das entradas de caixa é menor do que o valor presente das saídas de caixa.

Entre vários projetos, o mais atrativo é aquele que tem maior Valor Presente Líquido (VPL) (Casarottto \& Hopittke, 2010).

\subsection{3 - Taxa Interna de Retorno (TIR)}

Segundo Motta \& Calôba (2002), a Taxa Interna de Retorno (TIR) é um índice que indica a rentabilidade de um investimento por uma unidade de tempo, estabelece a taxa econômica necessária para igualar o valor de um investimento com seus retornos futuros e significa a taxa de remuneração que deve ser fornecida pelo projeto de modo que este iguale o seu investimento, após um período. A Taxa Interna de Retorno (TIR) é calculada utilizando-se a mesma fórmula descrita anteriormente, porém igualando-se o Valor Presente Líquido (VPL) a zero e utilizando-a como incógnita de taxa de conversão. 
Posteriormente a Taxa Interna de Retorno (TIR) é comparada com a Taxa Mínima de Atratividade (TMA) para verificar o desempenho do projeto, e:

- se a TIR for maior do que a TMA: significa que o investimento é economicamente atrativo;

- se a TIR for igual à TMA: o investimento está economicamente numa situação de indiferença;

- se a TIR for menor do que a TMA: o investimento não é economicamente atrativo, pois seu retorno é superado pelo retorno de um investimento sem risco.

Entre vários investimentos, o melhor será aquele que tiver a maior TIR.

\subsection{4 - Tempo de Retorno do Investimento (TRI) ou Método do Payback}

Segundo Motta \& Calôba (2002), o payback, tempo de retorno do investimento (TRI), também chamado de payout, é um indicador que determina o prazo de recuperação de um investimento e é utilizado para avaliar a atratividade de um investimento. É um método simples que consiste, essencialmente, em determinar o número de períodos necessários para recuperar o capital investido. É utilizado para avaliar a atratividade de um investimento, mas deve ser encarado com reservas, apenas como um indicador, não servindo de seleção entre alternativas de investimento. O payback corresponde ao período de tempo que o empreendimento necessita para que seja obtido o capital inicial investido neste projeto e pode ser expresso de forma simples, pela razão entre investimentos e receitas, na equação 3 :

Payback $(\mathrm{TRI})=\frac{\text { investimento inicial }}{\text { lucro operacional }}=$ tempo (dias, meses e anos) 


\subsection{0 - Análise Econômica}

Em uma análise econômica, o termo custo é usado para traduzir a compensação que os proprietários dos fatores de produção, usados para produzir determinado bem ou serviço, devem receber para continuar a fornecer este bem ou serviço e são classificados como fixos, que não se alteram com de acordo com a quantidade produzida; e variáveis que dependem do nível de produção. (Ghobril, 2008).

A eficiência é o objetivo natural da racionalidade econômica na distribuição dos recursos produtivos, já que as atividades agrícolas podem ser afetadas por um grande número de variáveis sobre as quais o produtor não tem controle, aumentando o grau de risco que pode causar variação nos preços dos produtos (Ghobril, 2008).

Os pesquisadores do Centro de Desenvolvimento da Tecnologia Nuclear (CDTN) dizem que, no Brasil, o uso da irradiação ainda não começou devido à falta de interesse do empresário e por falta de informação sobre o assunto, que é um dos maiores problemas para difusão dessa tecnologia. No Brasil, duas empresas já tentaram irradiar frutas em escala comercial, a Tech lon, em Manaus e a Surebean, no Rio de Janeiro, mas ambas apresentaram falhas na estratégia, pois, as unidades de irradiação devem ser instaladas próximas aos centros produtores de frutas para evitar que essas entrem em estado avançado de maturação e isto não aconteceu com as empresas em questão (CGEE, 2010).

Segundo Ramos (2001), a maneira que se conduz o produto durante a produção não é suficiente para manter uma boa qualidade. Para isso os tratamentos e técnicas de pós-colheita são essenciais a fim de que o produto chegue às mãos do consumidor com uma maior qualidade. O produtor brasileiro de frutas frescas para exportação tem no tempo seu principal aliado na tarefa de vender as safras aos distribuidores estrangeiros no momento e local certos.

Para conseguir os melhores preços no exterior, os produtores têm de calcular as datas exatas das entressafras dos países concorrentes e preparar seu 
produto mediante rigorosos critérios fitossanitários. Até chegar às gôndolas dos supermercados norte-americanos e europeus, as frutas passam por detalhado processo de cultivo, seleção, tratamento, embalagem e transporte. Tudo isso com tempo contado para chegar em boas condições ao exigente consumidor internacional (Ramos, 2001).

Quando se compara o custo da irradiação com algumas tecnologias atualmente utilizadas percebe-se que qualquer método de transformação alimentar adicionará custos para os alimentos; mas, reduzir as perdas aumentará a renda de produtores e comerciantes, compensando, assim, o custo de tratamento.

\subsection{1 - Análise econômica para Packing House com sistema para irradiação contínua}

Neste tipo de Packing house (FIG.13), também chamada de casa de embalagem ou galpão são executadas todas as atividades de preparo do produto com o objetivo de preservar a qualidade obtida no processo de produção. Tratase de uma usina de beneficiamento, onde se pode concentrar o produto de diversos produtores, classificar, lavar, embalar, paletizar e formar cargas para o mercado consumidor (Noronha, 1987).

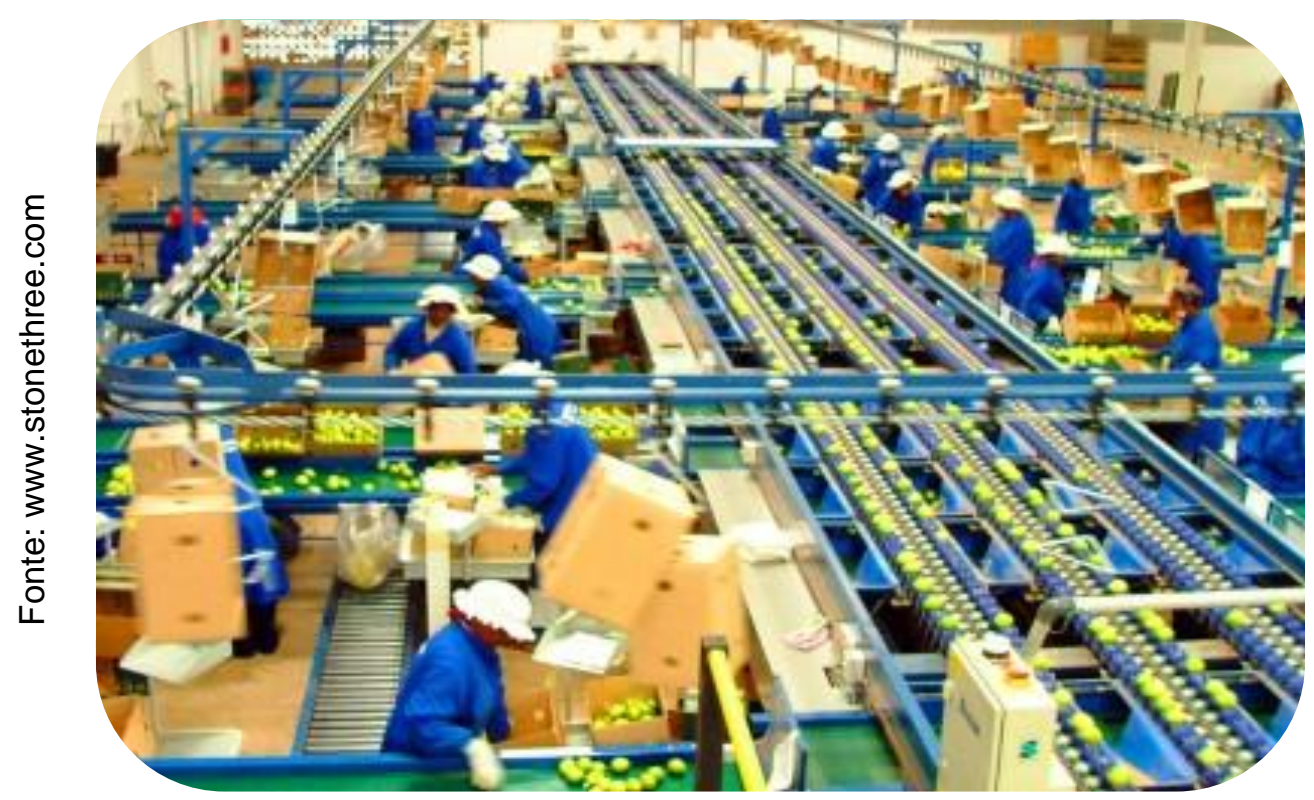

FIGURA 13 - Exemplo de Packing House para irradiação contínua 
O Packing house deve ser dimensionado de acordo com o volume a ser manuseado, usando como padrão o pico de produção. O custo de instalação de um Packing house com sistema para irradiação contínua para 60.000 toneladas por ano é de US\$ 4 milhões, fazendo com que o custo por tonelada seja de aproximadamente US\$66,67 e, com que o custo por quilograma seja de aproximadamente US\$ 0,07 (CGEE, 2010).

\subsection{2 - Análise econômica para Packing House com sistema hidrotérmico}

Neste tipo de Packing house (FIG.14), é executado tratamento hidrotérmico do produto que consiste na imersão do produto em água aquecida a uma determinada temperatura e por períodos de tempo pré-estabelecido, com parâmetros específicos para cada produto. Tal beneficiamento consiste, sobretudo, na seleção, limpeza, tratamento hidrotérmico (THT), estocagem, empacotamento e exportação. É importante que a temperatura não exceda o limite recomendado para não acelerar demasiadamente os processos metabólicos evitando dessa forma que o fruto apresente menor vida de prateleira (Noronha, 1987).

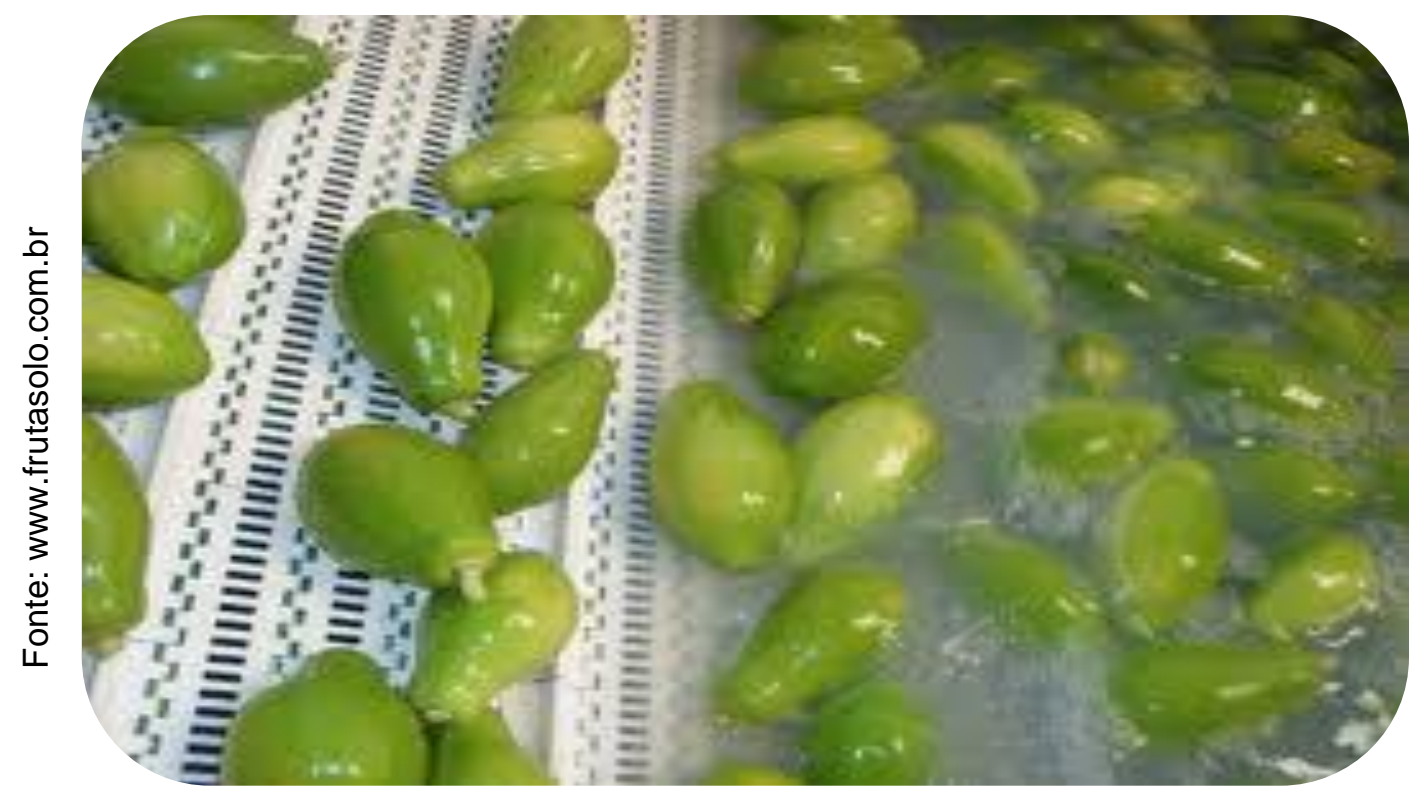

FIGURA 14 - Exemplo de Packing House com sistema hidrotérmico

O custo de um Packing house com sistema hidrotérmico para 60.000 toneladas por ano, é de US\$ 3 milhões, fazendo com que o custo por tonelada 
seja de aproximadamente US\$50,00 e, com que o custo por quilograma seja de aproximadamente US\$ 0,05 (CGEE, 2010).

Os Packing houses localizam-se nas principais regiões produtoras de frutas e hortaliças, geralmente, dentro das próprias propriedades ou nas mesmas cidades em que se situam as áreas de produção, devido a suas proximidades, condições de acesso e transporte (Noronha, 1987).

\subsection{3 - Análise econômica para irradiadores de alimentos de Cobalto 60 $\left({ }^{60} \mathrm{Co}\right)$}

Um estudo realizado no Brasil, por Hayes \& Farrar (1996), sob a coordenação da Food and Agricultural Organization (FAO) e da International Atomic Energy Atomic (IAEA) avaliou a viabilidade técnica e econômica da instalação de um irradiador de alimentos no Estado de São Paulo. O estudo utilizou valores conservadores de demanda, uma Taxa Interna de Retorno (TIR) estimada em $20 \%$ ao ano e Tempo de Retorno de Investimento (TRI) previsto em 7 anos. O Valor Presente Líquido (VPL) da instalação seria de US\$ 3,5 milhões no horizonte de análise de 10 anos e retorno sobre as vendas, a partir do $6^{\circ}$ ano de $67 \%$. Os resultados deste estudo foram considerados favoráveis.

Em 2002, foi realizado um estudo de viabilidade econômica da instalação de um irradiador multipropósito no Marrocos. Segundo Marfak (2002), o irradiador proposto custaria inicialmente US\$ 3,73 milhões, com custos operacionais de cerca de US\$10 milhões por ano, incluindo a depreciação dos equipamentos e edificações, salários, seguros, custos financeiros, custos de manutenção e reposição do Cobalto $60\left({ }^{60} \mathrm{Co}\right)$. As receitas médias anuais ultrapassariam os US\$15 milhões nos próximos 5 anos. A conclusão foi pela viabilidade técnica e econômica do investimento.

Segundo Ghobril (2008), os custos operacionais de um irradiador Centurion da MDS Nordion, é de US\$1,12 milhões e o custo total, incluindo o equipamento, da fonte e da construção civil é de US\$ 5,913 milhões. Os custos de manutenção seriam de $1 \%$ do capital e o de seguro de $3 \%$ do capital. A Taxa 
Interna de Retorno (TIR) mínima, no primeiro ano, seria de $16 \%$ a $35 \%$ chegando a atingir de $43 \%$ a $117 \%$ após 10 anos de operação.

O mesmo autor propõe, num estudo de viabilidade técnica e econômica, um irradiador com custos de implantação de US $\$ 1,8$ milhões, com reposição necessária de Cobalto $60\left({ }^{60} \mathrm{Co}\right)$, de 12,3\% ao ano. O custo operacional foi estimado em $12 \%$ do investimento inicial, o custo de manutenção foi estimado em 3,5\% do investimento inicial, os custos anuais de operação foram calculados em US\$ 800 mil, o Tempo de Retorno do Investimento (TRI) foi de 5 anos e 3 meses, a Taxa Interna de Retorno (TIR) é de 17,96\% a.a. e o Valor Presente Líquido (VPL) é de US\$ 1.288.694. A estimativa de custos para sua implementação é de aproximadamente US\$ 2 milhões, considerando um horizonte de projeto de 10 anos. Para este projeto o custo do alimento irradiado foi de:

- US\$15,00 por tonelada, isto é, de US\$ 0,015 por quilograma se considerarmos uma irradiação de dose baixa, até 1kGy, que inibe o brotamento, atrasa a maturação e promove a desinfestação de insetos e a inativação de parasitas;

- US\$100,00 por tonelada, isto é, de US\$ 0,10 por quilograma se considerarmos uma irradiação de dose média, de 1 a 10kGy, que reduz o número de microrganismos de decomposição e reduz ou elimina o número de microrganismos causadores de doenças;

- US\$180,00 por tonelada, isto é, de US\$ 0,18 por quilograma se considerarmos uma irradiação de dose alta, acima de $10 \mathrm{kGy}$, que reduz o número de microrganismos ao ponto da esterilidade.

Segundo o International Consultative Group on Food Irradiation (ICGFI) os custos de construção de um irradiador comercial de Cobalto $60\left({ }^{60} \mathrm{Co}\right)$ para irradiação de alimentos variam de US\$ 3 a US\$ 5 milhões, dependendo do tamanho, capacidade de processamento e alguns outros fatores, que são quase os mesmos para instalações de outras tecnologias para a irradiação comercial. 
Neste tipo de irradiador, usando-se doses baixas, de até 1kGy, que inibem o brotamento, atrasam a maturação, fazem a desinfestação de insetos e a inativação de parasitas, o custo varia entre US\$10,00 e US\$15,00 por tonelada, isto é, de US\$ 0,010 a US $\$ 0,015$ por quilo e usando-se doses altas, acima de 10kGy, que promove a redução do número de microrganismos ao ponto da esterilidade, o custo varia entre US\$100,00 e US\$250,00 por tonelada, isto é, de US $\$ 0,10$ a US $\$ 0,25$ por quilo (ICGFI, 1999b).

A FIG.15 mostra a parte externa do irradiador multipropósito, instalado no Centro de Tecnologia das Radiações, no IPEN.

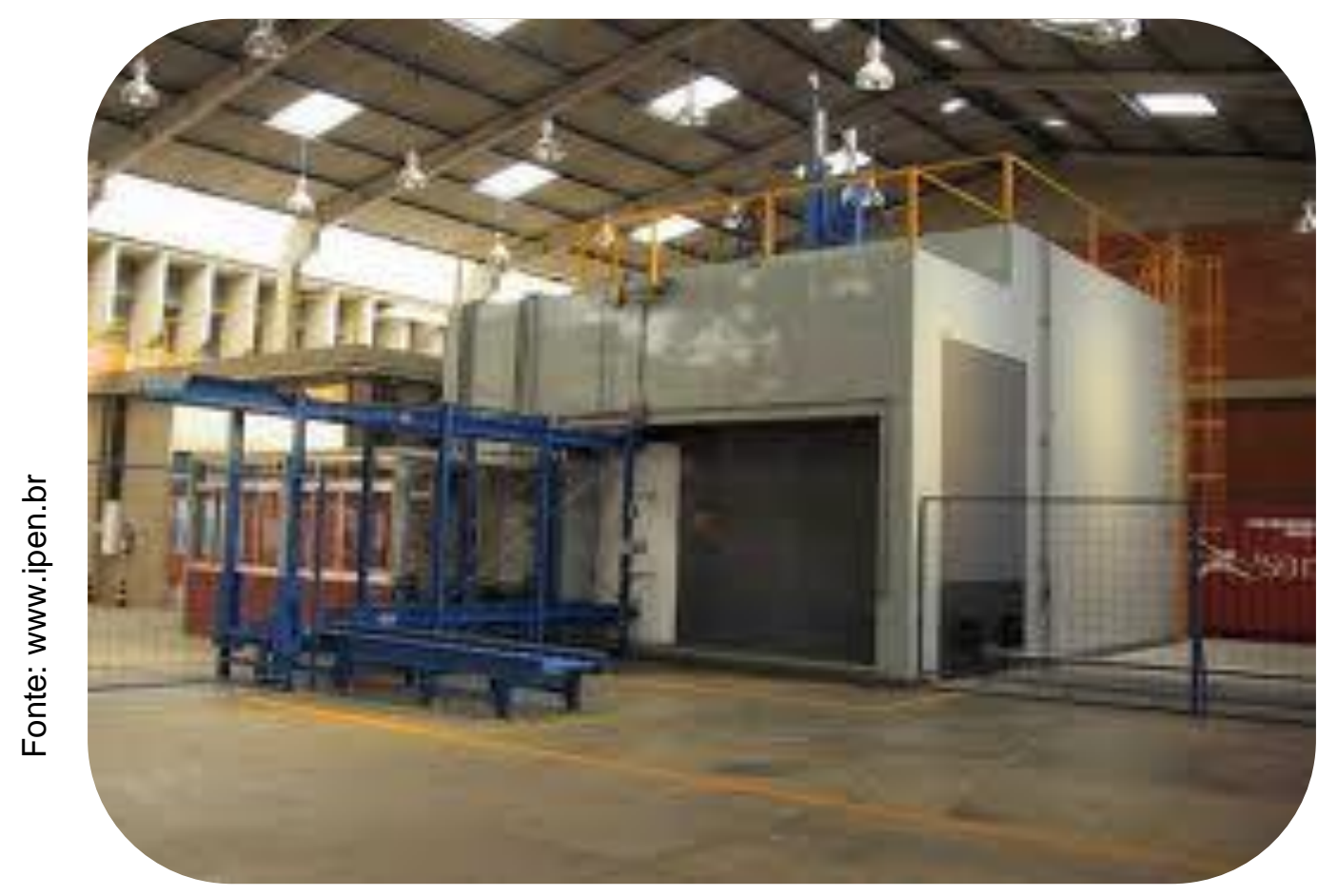

FIGURA 15 - Exemplo de irradiador de Cobalto $60\left({ }^{60} \mathrm{Co}\right)$

\subsection{4 - Análise econômica para aceleradores de elétrons}

Cunnighan (2009) realizou um estudo sobre a instalação de um acelerador de elétrons linear Portac $L \& W$, com $15 \mathrm{~kW}$ de potência e $10 \mathrm{MeV}$, com limite de peso de blindagem de aproximadamente 20 toneladas.

O acelerador linear é posicionado verticalmente e os elétrons são gerados, concentrados na forma de feixe e acelerados. Os produtos são 
transportados por uma esteira e irradiados ao passarem pelo feixe de elétrons, a taxa de dose aplicada ao produto pode ser variável e é controlada com o ajuste na velocidade da esteira transportadora, controlando-se o tempo de exposição do produto. O sistema foi projetado para operar 24 horas por dia, durante todos os dias do ano, utilizando apenas a eletricidade como fonte de energia.

O estudo prevê que o uso desta tecnologia pode ser aplicado a uma grande diversidade de produtos de diversas áreas, tais como material médico, cosméticos, fitoterápicos, polímeros, turfa, gemas e alimentos dentre outros.

Segundo Cunnighan (2009), a instalação descrita no estudo cumpre todas as metas específicas, sendo econômica e competitiva com outros métodos de irradiação de alimentos e, seu custo total, estimado, foi de aproximadamente US $\$ 2$ milhões, com custo de US\$15,00 a US\$20,00 por tonelada, isto é, de US\$ 0,015 a US $\$ 0,020$ por quilograma.

A Acelétron Irradiação Comercial é a única empresa, na América Latina, a prestar serviços de irradiação industrial, utilizando equipamento do tipo acelerador por feixes de elétrons de $18 \mathrm{kV}$ de potência, $10 \mathrm{MeV}$ de energia cada um, que utilizam a eletricidade como fonte de energia (informação verbal).

No sistema utilizado pela Acelétron, os produtos embalados são transportados por uma esteira e ao passarem pelo feixe de elétrons são irradiados. A taxa de dose de cada acelerador linear permanece constante, mas a dose aplicada ao produto pode ser variada ajustando-se a velocidade da esteira transportadora e controlando-se o tempo de exposição do produto ao feixe. 0 sistema de feixe de elétrons utilizado pela Acelétron foi projetado para operar 24 horas por dia, o ano inteiro e a capacidade de processamento é de, aproximadamente, 2 mil toneladas por mês. A tecnologia por feixe de elétrons permite irradiar industrialmente os mais variados produtos e materiais, tais como material médico-hospitalar, embalagens, cosméticos, fitoterápicos, polímeros e alimentos como especiarias, frutas frescas e desidratadas e vegetais frescos e desidratados, entre outros (informação verbal). 
Os aceleradores de elétrons da Acéletron são econômicos e competitivos com outros métodos de irradiação de alimentos, com custo de, aproximadamente, US\$ 40,00 para uma tonelada de grãos e US\$60,00 para de uma tonelada de frutas, isto é, de US $\$ 0,04$ a US $\$ 0,06$ por quilograma (informação verbal).

A FIG.16 apresenta o esquema de funcionamento e a parte externa de um acelerador de elétrons.
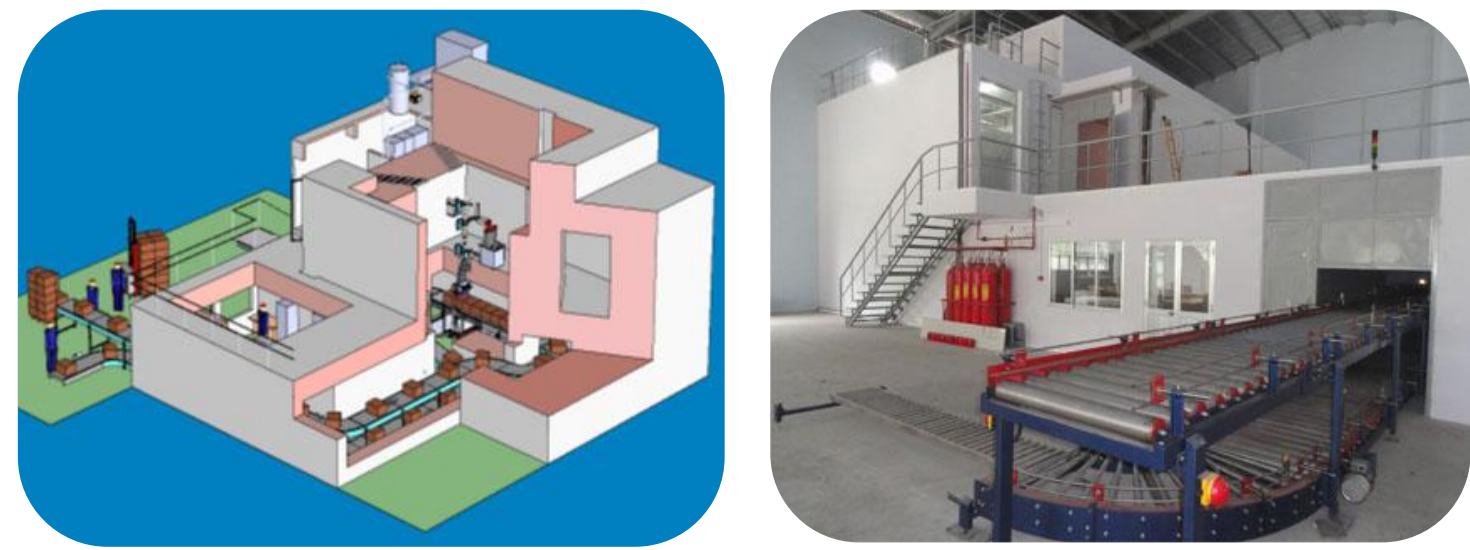

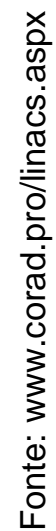

FIGURA 16 - Exemplo de acelerador de elétrons 


\section{3 - METODOLOGIA}

A pesquisa científica é uma ferramenta essencial para a geração do conhecimento. A gestão da tecnologia é importante por gerar, absorver e difundir os conhecimentos científicos e tecnológicos, pois o seu desenvolvimento está integrado às atividades de pesquisa.

Neste trabalho foi feito um estudo sobre a viabilidade econômica da implantação da tecnologia de irradiação de alimentos por meio de um levantamento sistemático da literatura especializada para a verificação do custo de implantação dessa tecnologia e o acréscimo ligado a esse custo que o produtor terá.

O estudo analisou a viabilidade econômico-financeira de um projeto, no que significa estimar as perspectivas de desempenho financeiro resultante do próprio projeto, e os orçamentos que servem para trazer uma estimativa dos níveis que tornariam viáveis e cobririam os custos envolvidos. Envolveu, tanto os aspectos estritamente econômicos, como as informações necessárias para avaliar e decidir as implicações de um projeto. Foram analisadas as variáveis que afetam os custos, como o Valor Presente Líquido (VPL), a Taxa Interna de Retorno (TIR), Tempo de retorno do Investimento (TRI) e o Impacto Ambiental, mesmo sabendo que estes custos são apenas uma das variáveis e que a disponibilidade do alimento em todo o ano, o tempo de armazenamento e a distribuição também o são.

Realizou-se uma investigação com o objetivo geral de compreender a lógica de mercado e as estratégias competitivas das empresas por meio de estudo de seus custos para a implantação de uma planta de irradiação.

Também foi realizada uma pesquisa em uma Instituição de Ensino Superior, o Centro Universitário Fundação Santo André (CUFSA), localizado no 
município de Santo André. Esta Instituição foi selecionada em função de compor o quadro de professores, desde 1987, o que facilitou a permissão para aplicação da pesquisa e o acesso aos alunos.

Antes da pesquisa final, foi elaborado, no início de 2011, um pré-teste com 50 alunos, que ajudou na verificação de algum tipo de dubiedade nas questões, resultando em nenhuma questão eliminada. Este pré-teste também ajudou na edição do filme explicativo, de 15 minutos, que foi utilizado.

Para a realização da pesquisa, foram escolhidos 664 alunos de graduação do Centro Universitário Fundação Santo André (CUFSA). O tamanho dessa amostra foi calculado segundo a metodologia Cochran (1977), usando-se valor crítico, que corresponde ao grau de confiança desejado, em 99\% e margem de erro ou erro de estimativa de 5\%, utilizando-se a equação 4 :

$$
n=\frac{\left(Z \frac{\alpha}{2}\right)^{2} \cdot p \cdot q}{(E)^{2}}
$$

na qual:

n = número de indivíduos da amostra

$Z_{\frac{\alpha}{2}}=$ valor crítico que corresponde ao grau de confiança desejado.

$\mathrm{p}=$ proporção populacional de indivíduos que pertence à categoria que estamos interessados em estudar.

q = proporção populacional de indivíduos não pertencentes à categoria que estamos interessados em estudar. $(q=1-p)$

$E=$ margem de erro ou erro máximo de estimativa. Identifica a diferença máxima entre a proporção amostral e a verdadeira proporção populacional $(p)$. 
A maioria dos alunos, que foram convidados a participar desse estudo, estava cursando Licenciatura em Matemática, Licenciatura e Bacharelado em Química, Licenciatura em Letras, Licenciatura em Pedagogia, Psicologia, Bacharelado em Sistemas de Informação e Licenciatura e Bacharelado em Ciências Biológicas.

A pesquisa foi realizada no auditório do prédio da Faculdade de Filosofia, Ciências e Letras (FAFIL) do Centro Universitário Fundação Santo André (CUFSA), com capacidade para 200 pessoas, que possui projetor multimídia e telão para exibição de filmes. Os instrumentos utilizados para a pesquisa foram um questionário, ANEXO A, composto de 20 questões, dividido em três partes e um filme explicativo.

$\mathrm{Na}$ aplicação da pesquisa, os alunos, ao entrarem no auditório, recebiam um questionário com 14 questões referentes à parte I, questões de 01 a 08, sobre a caracterização socioeconômica e demográfica e a parte II, com questões de 09 a 14, com informações sobre as aplicações da energia nuclear, sem esclarecimentos prévios. Durante a aplicação das partes I e II do questionário não foram respondidas perguntas sobre o assunto.

Após os alunos responderem essas questões, as partes I e II do questionário foram recolhidas e passou-se à exibição de um filme explicativo sobre os trabalhos desenvolvidos pelo Instituto de Pesquisas Energéticas e Nucleares (IPEN), e a irradiação de alimentos, especificamente. Após a exibição, não foram respondidas perguntas sobre $\mathrm{o}$ assunto.

Em seguida, foi entregue aos alunos a parte III, com questões de 15 a 20, das informações sobre a intenção de compra de alimentos irradiados, após esclarecimentos e novamente, não foram respondidas perguntas sobre o assunto.

O banco de dados foi construído utilizando-se o software Excel (2010), e para as análises estatísticas foi utilizado o software MINITAB (2008). 


\section{4 - RESULTADOS E DISCUSSÃO}

\section{1 - Análise da viabilidade econômica}

$\mathrm{Na}$ elaboração de um projeto, o processo de produção deve ser objetivo e possuir informações sobre a quantidade que vai ser produzida, sobre quais são as matérias primas utilizadas, quais são os equipamentos que devem ser comprados, qual o tipo de instalação necessária e qual o tipo de energia vai ser consumida (Rozenfeld et al., 2006).

Como explicam Motta \& Calôba (2002), o que justifica a existência de uma empresa é, principalmente, a geração de lucro. Para os investidores, para que um projeto seja atrativo, não basta que tenha um resultado positivo, é preciso que a quantidade de lucro gerada, seja maior do que o investidor poderia obter com outros investimentos, portanto, a essência da avaliação econômico-financeira é medir o retorno financeiro do projeto comparando-o com outros investimentos.

Verificou-se que a análise custo-benefício pode ser feita por meio de diversos indicadores financeiros, tais como o Fluxo de Caixa $(F C)$, o Valor Presente Líquido (VPL), a Taxa Interna de Retorno (TIR) e o Tempo de Retorno do Investimento (TRI) ou Método do Payback. O objetivo é sempre o de identificar o melhor momento para a aplicação dos recursos financeiros existentes, de maneira a fortalecer as condições de o projeto dar certo e da tentativa de neutralizar os fatores que podem dificultar as possibilidades de êxito do projeto.

Verificou-se, também que, como o Valor Presente Líquido (VPL) é encontrado por meio do cálculo de quanto os futuros pagamentos somado a um custo inicial estariam valendo atualmente, um projeto de investimento potencial deve ser empreendido se o valor presente de todas as entradas de caixa, menos o valor presente de todas as saídas de caixa for maior que zero. Se o VPL >0, o investimento é viável; se o VPL $=0$, o investimento é indiferente e, se o $\mathrm{VPL}<0$, 
o investimento não é economicamente atrativo, já que o valor presente das entradas de caixa é menor do que o valor presente das saídas de caixa. Já a Taxa Interna de Retorno (TIR) é a taxa que o investidor obtém, em média, em cada ano, sobre os capitais que se mantêm investidos no projeto, enquanto o investimento inicial é recuperado progressivamente. A Taxa Interna de Retorno (TIR) é a taxa necessária para igualar o valor de um investimento (valor presente) com os seus respectivos retornos futuros ou saldos de caixa; sendo assim, na escolha entre vários investimentos, o melhor será aquele que tiver a maior Taxa Interna de Retorno (TIR). Matematicamente, a Taxa Interna de Retorno (TIR) é a taxa de juros que torna o valor presente das entradas de caixa igual ao valor presente das saídas de caixa do projeto de investimento.

Com as informações de como calcular o investimento que será utilizado na instalação de um projeto, o estudo feito por meio de pesquisas bibliográficas sobre a viabilidade econômica, indica que o processo de irradiação de alimentos, apesar de possuir um investimento relativamente alto, traz retorno rápido para um processo contínuo.

Os custos que foram apresentados neste trabalho são:

- de um Packing house com sistema para irradiação contínua para 60.000 toneladas por ano é de US\$ 4 milhões, fazendo com que o custo por tonelada seja de aproximadamente US $\$ 66,67 \mathrm{e}$, com que o custo por quilograma seja de aproximadamente US\$ 0,07 ;

- de um Packing house com sistema hidrotérmico para 60.000 toneladas por ano, de US\$ 3 milhões fazendo com que o custo por tonelada seja de aproximadamente US\$50,00 e, com que o custo por quilograma seja de aproximadamente US $\$ 0,05$;

- de um irradiador comercial de Cobalto $60\left({ }^{60} \mathrm{Co}\right)$ para irradiação de alimentos varia de US\$ 3 a US\$ 5 milhões e usando-se doses baixas, de até $1 \mathrm{kGy}$, o custo varia entre US $\$ 10,00$ e US\$15,00 por tonelada, isto é, de US\$ 0,010 a US $\$ 0,015$ por quilo e usando- 
se doses altas, acima de 10kGy, o custo varia entre US\$100,00 e US\$ 250,00 por tonelada, isto é, de US\$ 0,10 a US\$ 0,25 por quilo;

- de um irradiador comercial de Cobalto $60\left({ }^{60} \mathrm{Co}\right)$ para irradiação de alimentos cuja estimativa de custos é de aproximadamente US\$2 milhões, com custo de US\$15,00 por tonelada, isto é, de US\$ 0,015 por quilograma se considerarmos uma irradiação de dose baixa, até $1 \mathrm{kGy}$; US $\$ 100,00$ por tonelada, isto é, de US\$ 0,10 por quilograma se considerarmos uma irradiação de dose média, de 1 a 10kGy e US\$180,00 por tonelada, isto é, de US\$ 0,18 por quilograma se considerarmos uma irradiação de dose alta, acima de 10 kGy.

- de um acelerador de elétrons para irradiação de alimentos cuja estimativa de custos é de aproximadamente US\$2 milhões, com custo de US\$15,00 a US\$20,00 por tonelada, isto é, de US\$ 0,015 a US $\$ 0,020$ por quilograma.

- de um acelerador de elétrons para irradiação de alimentos cuja estimativa de custos é de aproximadamente US\$40,00 para uma tonelada de grãos e US\$ 60,00 para uma tonelada de frutas, isto é, de US\$ 0,04 a US\$0,06 por quilograma.

É preciso, ainda, salientar que segundo o CGEE (2010), quando nos referimos às instalações de irradiadores no Brasil, podemos afirmar que:

- são poucas e concentradas nos grandes centros, independentemente dos polos de produção e fabricação;

- é difícil o tratamento de produtos para doses inferiores a 5 kGy;

- que a situação econômica de muitos agronegócios não permite o autofinanciamento de novas tecnologias;

- que existem os problemas com o custo adicional da irradiação;

- que existem os problemas com as dificuldades logísticas;

- que faltam irradiadores multipropósitos no país. 
Após a análise dos custos apresentados e com o conhecimento de que qualquer método de transformação alimentar adicionará custos para os alimentos pode ser estabelecido que a utilização da radiação ionizante torna-se viável economicamente quando comparada aos outros tipos de tratamento apresentados, pois, reduzindo as perdas, os produtores e comerciantes aumentarão sua renda, compensando, assim, o custo de tratamento e conseguindo preços melhores, já que terão a opção de comercializar o seu produto, ao longo do ano, no período de pico da safra e também na entressafra, reduzindo o custo repassado ao consumidor.

\section{2 - Pesquisa sobre a predisposição dos consumidores em arcar com o custo do alimento processado por ionização}

Neste trabalho, realizou-se uma pesquisa, durante o ano de 2011, em uma Instituição de Ensino Superior, o Centro Universitário Fundação Santo André (CUFSA), com o objetivo de traçar um perfil em relação à predisposição para compra e consumo de alimentos irradiados. Foram entrevistados 664 consumidores e o tamanho dessa amostra foi calculado segundo a metodologia Cochran (1977), usando-se grau de confiança de $99 \%$ e margem de erro de $5 \%$.

Os instrumentos utilizados para a pesquisa foram um questionário composto de 20 questões, dividido em três partes, a parte I, questões de 01 a 08 , sobre a caracterização socioeconômica e demográfica; a parte II, questões de 09 a 14, com informações sobre as aplicações da energia nuclear, sem esclarecimentos prévios e a parte III, questões de 15 a 20, com as informações sobre a intenção de compra de alimentos irradiados, após esclarecimentos; e um filme explicativo sobre os trabalhos desenvolvidos pelo Instituto de Pesquisas Energéticas e Nucleares (IPEN), e a irradiação de alimentos, especificamente. Foram construídas tabelas de cada uma das partes da pesquisa e gráficos para facilitar as análises, a visualização das respostas e as discussões necessárias.

\subsection{1 - Análise da caracterização socioeconômica e demográfica}

Nesta primeira parte da pesquisa, os alunos responderam as questões 
de 01 a 08 referentes à caracterização socioeconômica e demográfica; a TAB.8 apresenta os resultados encontrados.

TABELA 8 - Caracterização socioeconômica e demográfica

\begin{tabular}{|c|c|c|}
\hline Características & $\mathbf{n}$ & $\%$ \\
\hline \multicolumn{3}{|c|}{ Município de residência } \\
\hline Região do ABC & 602 & 91 \\
\hline São Paulo & 62 & 9 \\
\hline \multicolumn{3}{|l|}{ Gênero } \\
\hline Masculino & 298 & 45 \\
\hline Feminino & 366 & 55 \\
\hline \multicolumn{3}{|l|}{ Faixa Etária } \\
\hline 18 anos a 27 anos & 520 & 78 \\
\hline 28 anos a 37 anos & 87 & 13 \\
\hline 38 anos a 47 anos & 26 & 4 \\
\hline 48 anos a 57 anos & 26 & 4 \\
\hline 58 anos a 67 anos & 5 & 1 \\
\hline \multicolumn{3}{|l|}{ Estado civil } \\
\hline solteiro(a) & 515 & 78 \\
\hline casado(a) & 93 & 14 \\
\hline divorciado(a) & 11 & 2 \\
\hline separado(a) & 15 & 2 \\
\hline relação estável & 30 & 5 \\
\hline viúvo(a) & 0 & 0 \\
\hline \multicolumn{3}{|l|}{ Número de filhos } \\
\hline nenhum & 556 & 84 \\
\hline 01 (um) & 67 & 10 \\
\hline 02 (dois) & 36 & 5 \\
\hline 03 (três & 0 & 0 \\
\hline mais que 03 (três) & 5 & 1 \\
\hline
\end{tabular}


(continuação)

TABELA 8 - Caracterização socioeconômica e demográfica

\begin{tabular}{|c|c|c|}
\hline Características & $\mathbf{n}$ & $\%$ \\
\hline \multicolumn{3}{|l|}{ Grau de escolaridade } \\
\hline superior incompleto & 600 & 90 \\
\hline superior completo & 64 & 10 \\
\hline \multicolumn{3}{|l|}{ Faixa salarial pessoal mensal } \\
\hline até $\mathrm{R} \$ 1000,00$ & 268 & 40 \\
\hline entre $R \$ 1000,00$ e $R \$ 2000,00$ & 129 & 19 \\
\hline entre $R \$ 2000,00$ e $R \$ 4000,00$ & 139 & 21 \\
\hline entre $R \$ 4000,00$ e $R \$ 6000,00$ & 20 & 3 \\
\hline mais de $R \$ 6000,00$ & 11 & 2 \\
\hline sem rendimento & 30 & 5 \\
\hline não sabe & 11 & 2 \\
\hline não quer responder & 56 & 8 \\
\hline \multicolumn{3}{|l|}{ Faixa salarial familiar mensal } \\
\hline até $\mathrm{R} \$ 1000,00$ & 20 & 3 \\
\hline entre $R \$ 1000,00$ e $R \$ 2000,00$ & 77 & 12 \\
\hline entre $R \$ 2000,00$ e $R \$ 4000,00$ & 268 & 40 \\
\hline entre $R \$ 4000,00$ e $R \$ 6000,00$ & 93 & 14 \\
\hline mais de $R \$ 6000,00$ & 88 & 13 \\
\hline sem rendimento & 11 & 2 \\
\hline não sabe & 56 & 8 \\
\hline não quer responder & 51 & 8 \\
\hline
\end{tabular}

Fonte - Centro Universitário Fundação Santo André, 2011.

OBS: Salário Mínimo, vigente em 2011, no Estado de São Paulo é de R $\$ 600,00$.

A maioria dos alunos entrevistados (91\%) reside na região do Grande ABC (FIG.17), que engloba as cidades de Santo André, São Bernardo do Campo, São Caetano do Sul, Mauá, Diadema, Ribeirão Pires; apenas 9\% dos entrevistados residem no município de São Paulo, o que já era esperado, já que o Centro Universitário localiza-se no município de Santo André. 


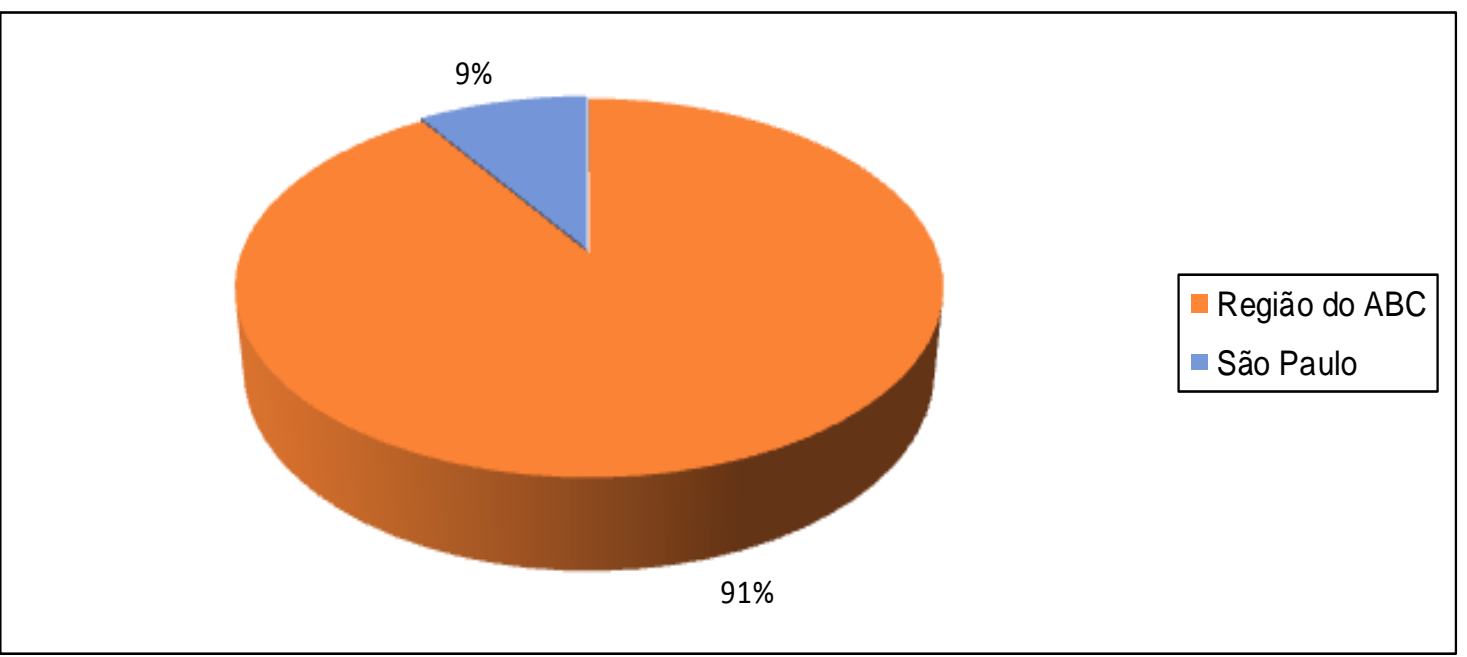

FIGURA 17 - Município de residência

Dos 664 consumidores entrevistados, $55 \%$ eram do sexo feminino e $45 \%$ do sexo masculino. (FIG.18).

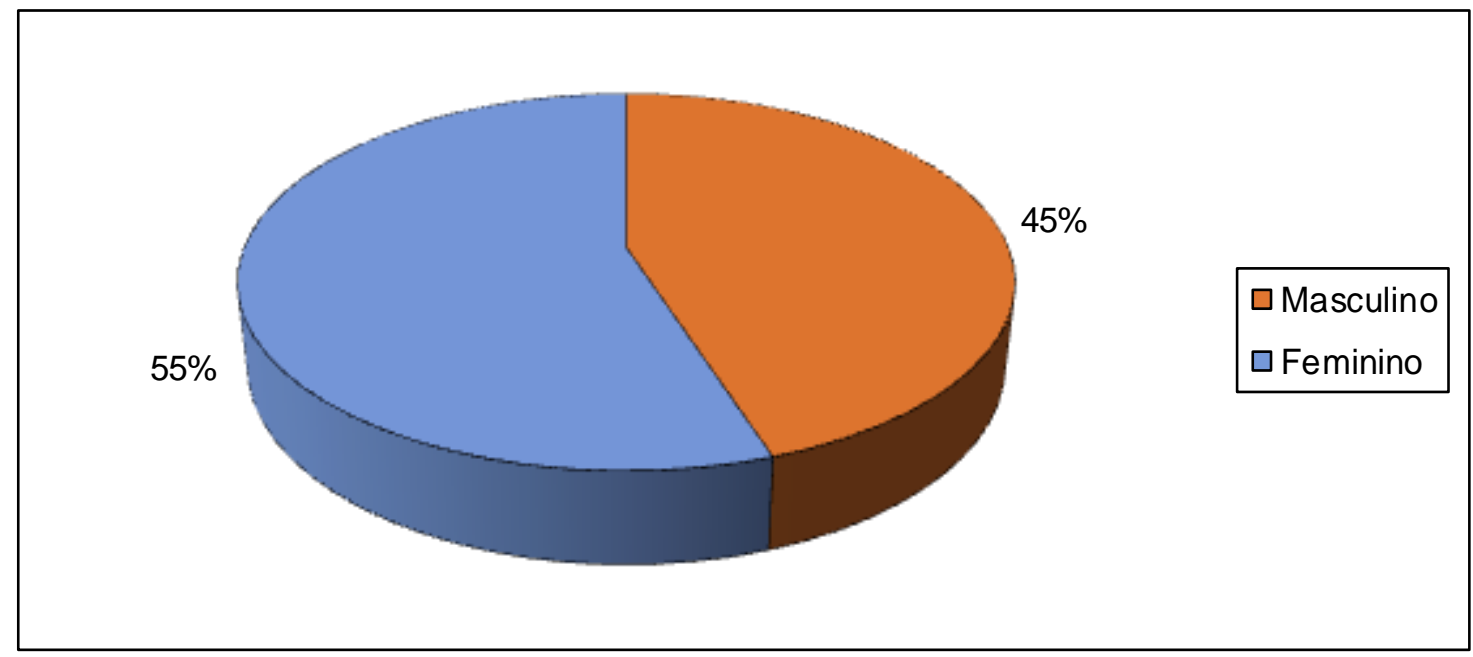

FIGURA 18 - Gênero

Como a pesquisa foi realizada em um Centro Universitário, a faixa etária predominante, $78 \%$, foi de consumidores entre 18 anos e 27 anos, mas $13 \%$ dos consumidores entrevistados tinham entre 28 anos e 37 anos, $4 \%$ tinham entre 38 anos e 47 anos, 4\% tinham entre 48 anos e 57 anos e 1\% tinha idade entre 58 e 67 anos (FIG.19). 


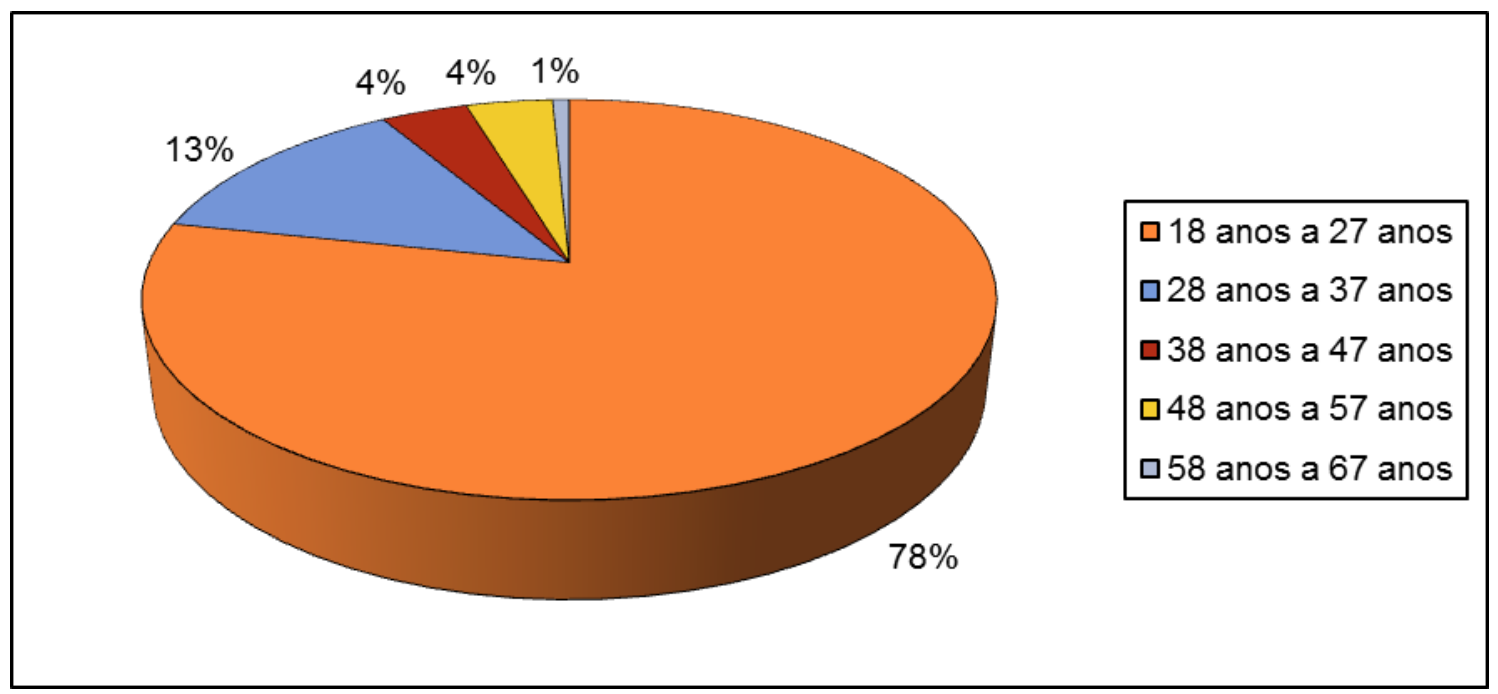

FIGURA 19 - Faixa etária

Dentre os consumidores entrevistados, $78 \%$ são solteiros (as), 14\% são casados (as) e $8 \%$ se declaram divorciados (as), separados (as) ou em uma relação estável (FIG.20).

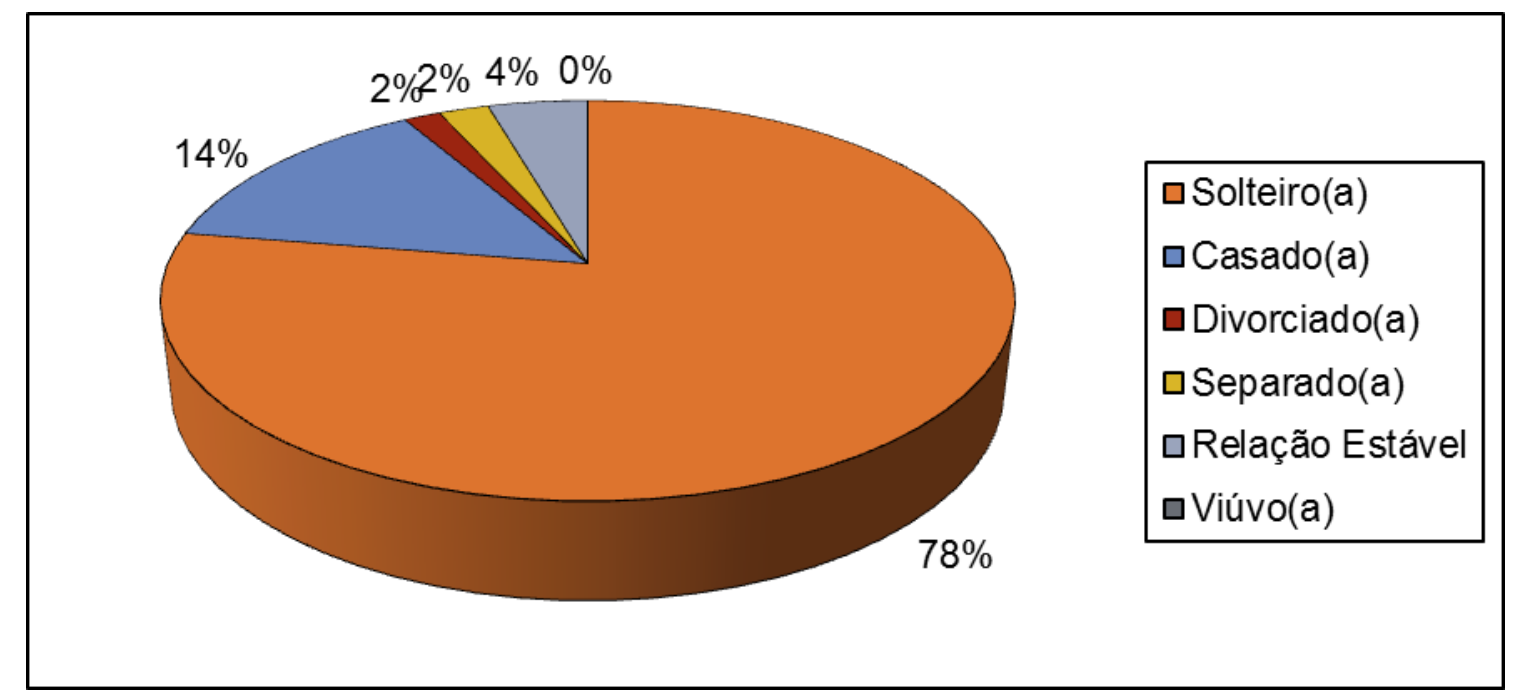

FIGURA 20 - Estado Civil

Segundo o Instituto Brasileiro de Geografia e Estatística (IBGE), a média do número de filhos por família vem diminuindo a cada ano; em 1960, a média era de 6,3 filhos; em 2001, esta média caiu para 1,6 filhos e hoje em dia esta média está em 1,5 filhos por família (IBGE, 2012). Como os universitários são, em sua maioria, solteiros, $84 \%$ não têm filhos, $10 \%$ têm apenas um filho, $5 \%$ têm dois filhos e 1\% têm mais que três filhos (FIG.21). 


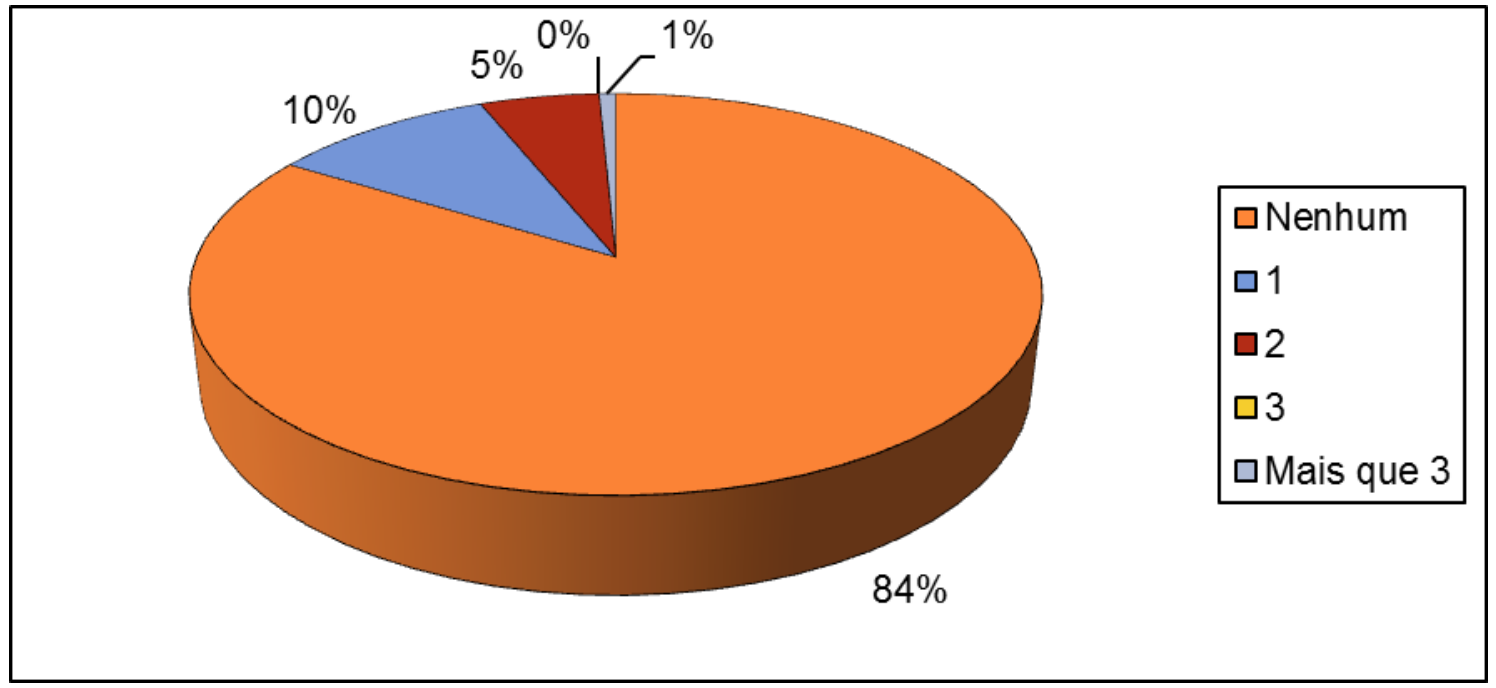

FIGURA 21 - Número de filhos

Apesar de o questionário ter sido aplicado em uma Instituição de Ensino Superior, onde se espera que os alunos estejam iniciando a vida acadêmica, verificou-se que $10 \%$ dos estudantes já possuem outra graduação anterior e que $90 \%$ estão cursando a primeira graduação (FIG.22).

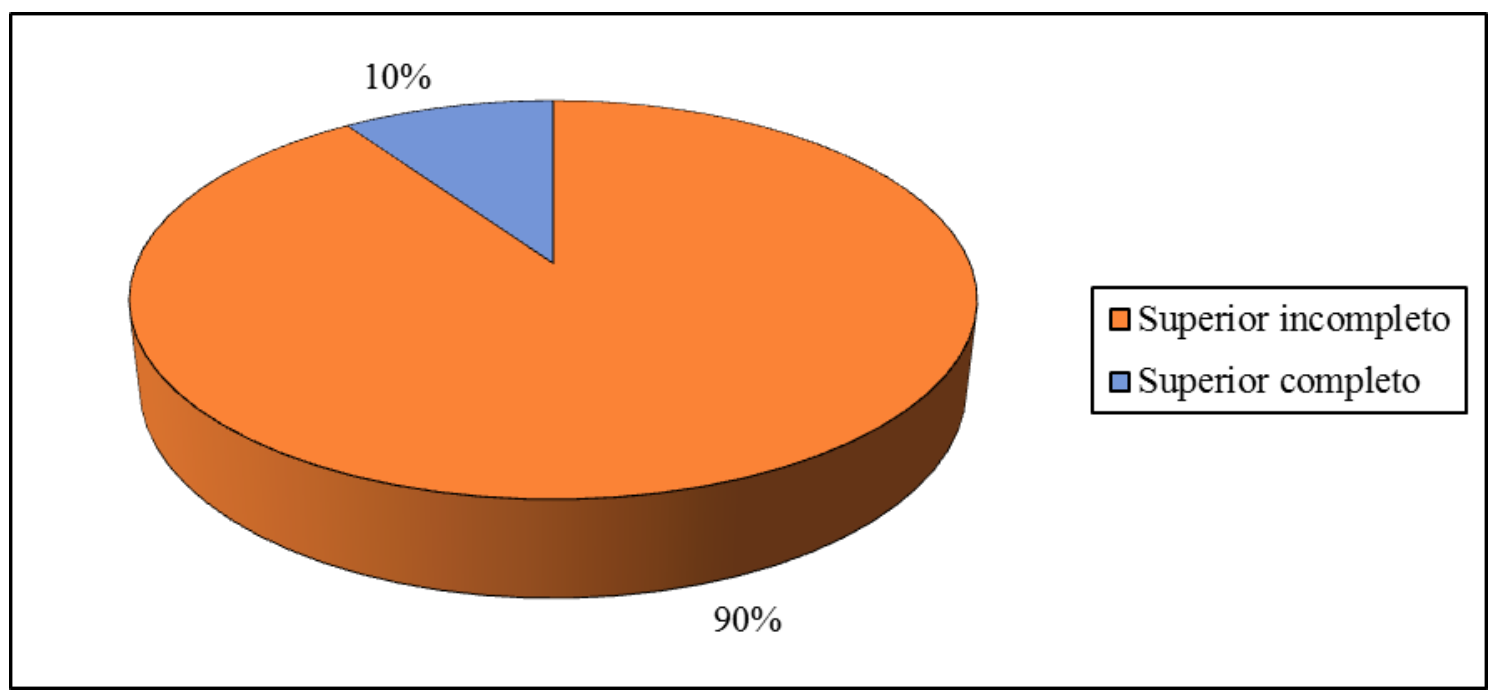

FIGURA 22 - Grau de escolaridade

De acordo com o Instituto Brasileiro de Geografia e Estatística (IBGE) o salário médio do trabalhador brasileiro, em 2011, foi de aproximadamente $R \$$ 1.700,00 (IBGE, 2012).

Observa-se, na FIG.23, que 40\% dos consumidores entrevistados possuem renda de até $\mathrm{R} \$ 1000,00$ e como estão cursando o nível superior, 
acredita-se que os estudantes dos primeiros anos do curso ainda não estejam atuando em sua futura área de formação. Já com a proximidade do término de seus cursos, temos $19 \%$ com renda entre $R \$ 1000,00$ e $R \$ 2000,00,21 \%$ entre $R \$ 2000,00$ e $R \$ 4000,00,3 \%$ entre $R \$ 4000,00$ e $R \$ 6000,00$ e ainda, $8 \%$ que possuem renda superior a $\mathrm{R} \$ 6000,00$.

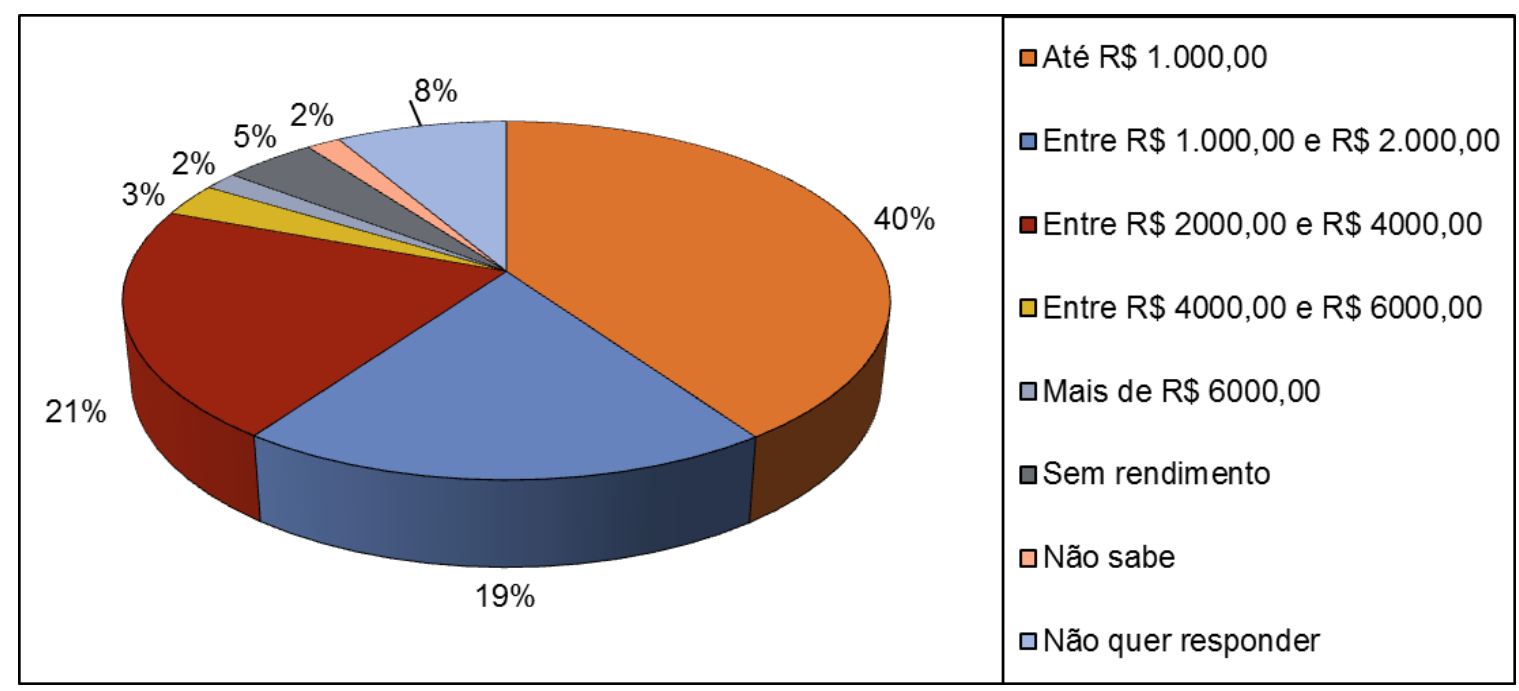

FIGURA 23 - Faixa salarial pessoal mensal

Ainda segundo o Instituto Brasileiro de Geografia e Estatística (IBGE), o grande ABC possui cerca de 2,5 milhões de habitantes e tem, atualmente, o quarto maior PIB brasileiro, ficando atrás apenas das cidades de São Paulo, Rio de Janeiro e Brasília. A renda familiar média mensal, no Grande $A B C$, é de aproximadamente $\mathrm{R} \$ 1400,00$ (IBGE, 2012).

Observando-se a FIG.24 no que diz respeito à faixa salarial familiar mensal, apenas 3\% das famílias possuem renda de até $R \$ 1000,00,12 \%$ das famílias possuem renda entre $R \$ 1000,00$ e $R \$ 2000,00,40 \%$ das famílias possuem renda entre $R \$ 2000,00$ e $R \$ 4000,00,14 \%$ das famílias possuem renda entre $R \$ 4000,00$ e $R \$ 6000,00$ e $13 \%$ das famílias possuem renda superior a $R \$$ 6000,00 . 


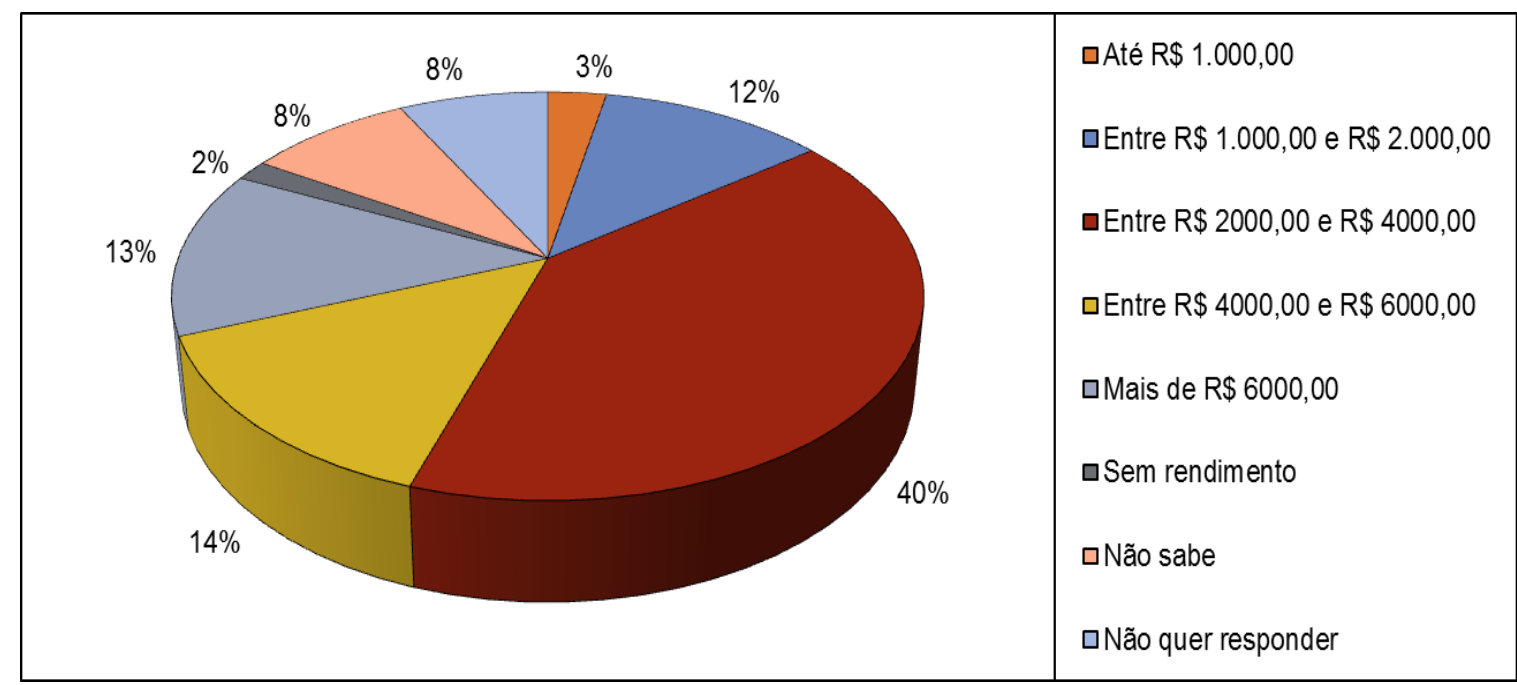

FIGURA 24 - Faixa salarial familiar mensal

\subsection{2 - Análise do conhecimento sobre as aplicações da energia nuclear sem esclarecimentos prévios}

Nesta segunda parte da pesquisa os alunos passaram a responder as questões de 09 a 14 do questionário, que diziam respeito ao conhecimento sobre as aplicações da energia nuclear, sem esclarecimentos prévios e, como mencionado anteriormente, não foi respondida nenhuma pergunta; qualquer conhecimento prévio sobre o assunto já fazia parte do conhecimento do entrevistado. A TAB.9 apresenta os resultados encontrados.

TABELA 9 - Informações sobre as aplicações da energia nuclear sem esclarecimentos prévios

\begin{tabular}{l|c|c}
\hline Informações & $\mathbf{n}$ & $\%$ \\
\hline Impressão sobre a energia nuclear & 224 & 34 \\
\hline Boa & 440 & 66 \\
Ruim & \multicolumn{3}{|c}{} \\
\hline Conhecer que materiais farmacêuticos (fraldas descartáveis, gazes, seringas, \\
agulhas etc.) e alguns cosméticos disponíveis no mercado são esterilizados por \\
meio da irradiação. & 226 & 34 \\
\hline Sim & 438 & 66 \\
Não
\end{tabular}


(continuação)

TABELA 9 - Informações sobre as aplicações da energia nuclear sem esclarecimentos prévios

\section{Informações}

\begin{tabular}{l|l}
$\mathbf{n}$ & $\%$
\end{tabular}

Conhecer que uma das aplicações da energia nuclear é a irradiação de alimentos.

\begin{tabular}{l|c|c}
\hline Sim & 172 & 26 \\
Não & 492 & 74 \\
\hline Preocupação com os alimentos que consome. & 624 & 94 \\
\hline Sim & 40 & 6 \\
Não & \multicolumn{3}{|l}{} \\
\hline Conhecer que a irradiação de alimentos produz toxinas nos alimentos ou acarreta \\
perda de nutrientes. & 448 & 67 \\
\hline Sim & 216 & 33 \\
Não & 207 & 31 \\
\hline Consumir alimentos irradiados. & 457 & 69 \\
\hline Sim & & \\
Não
\end{tabular}

Fonte - Centro Universitário Fundação Santo André, 2011.

A maioria dos consumidores brasileiros faz uma ideia errada na interpretação dos termos irradiação e radioatividade. Ambos são frequentemente relacionados com a imagem negativa que a energia nuclear deixou ao mundo após as bombas atômicas de Hiroshima e Nagasaki, o acidente nuclear de Chernobyl, o desastre com o Césio 137, no Brasil, e recentemente o acidente em Fukushima, no Japão, em relação aos malefícios causados à saúde humana (França, 2000; Boaventura, 2004; Ornellas et al., 2006; Kuramoto, 2008).

Segundo Fox (2002), os consumidores não reagem de forma positiva quando questionados sobre o consumo de alimentos irradiados, pois associam consumo de alimentos irradiados com maior risco de aparecimento de câncer.

$\mathrm{Na}$ questão 09 (FIG.25), os consumidores entrevistados foram questionados a respeito da sua impressão, boa ou ruim, quando ouvem falar da 
energia nuclear e $66 \%$ declararam que possuem uma impressão ruim.

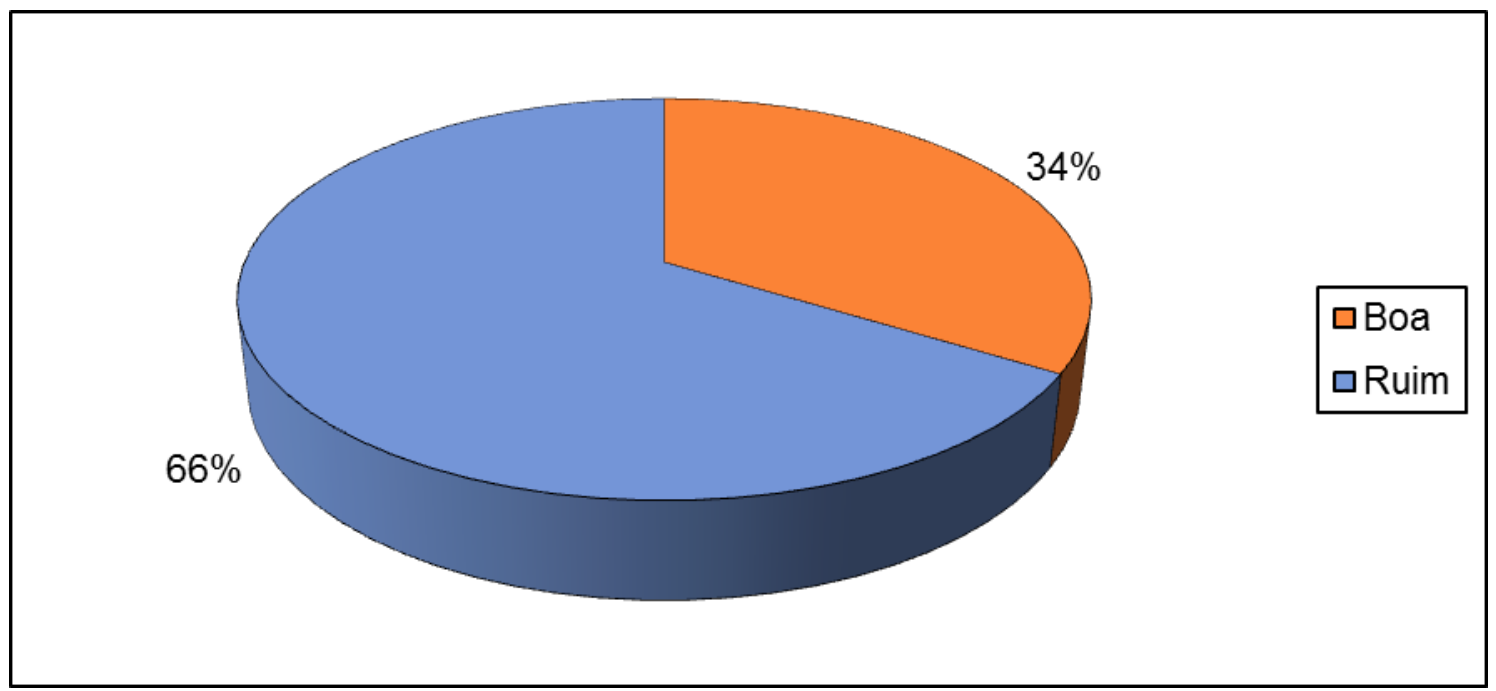

FIGURA 25 - Quando você ouve falar em energia nuclear, a impressão que você tem é?

Quando questionados sobre os materiais e cosméticos que são tratados pela radiação ionizante, também $66 \%$ dos entrevistados disseram não conhecer o uso da irradiação para este tipo de produto e 34\% disseram que já sabiam (FIG.26).

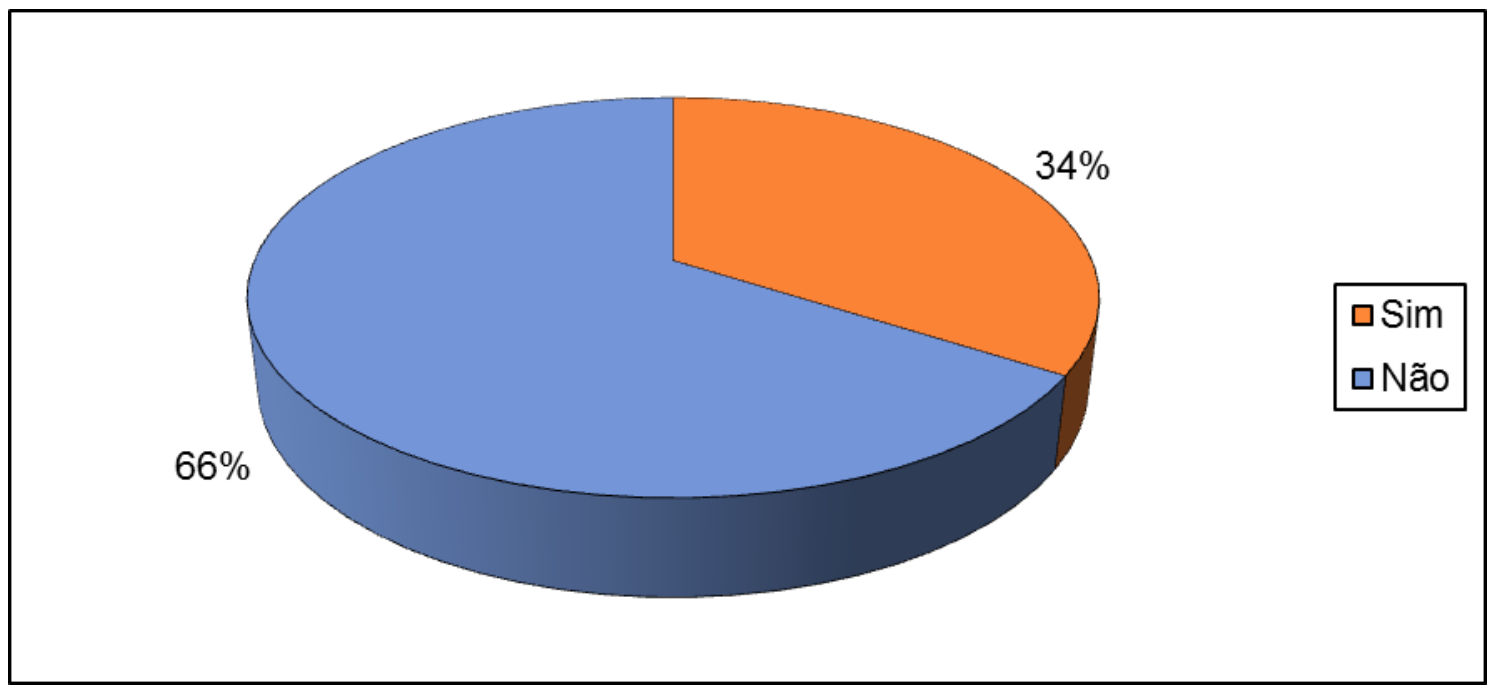

FIGURA 26 - Você sabia que materiais farmacêuticos (fraldas descartáveis, gazes, seringas, agulhas, etc) e alguns cosméticos disponíveis no mercado são esterilizados por meio da irradiação?

Verifica-se, neste momento, que $66 \%$ dos consumidores entrevistados não possuem qualquer tipo de informação sobre a irradiação, seja de alimentos 
ou de outros tipos de produtos.

Na questão 11 (FIG.27), perguntou-se aos consumidores se sabiam que uma das aplicações da energia nuclear era a irradiação de alimentos e 74\% afirmaram que desconheciam o fato. Apesar de 34\% dos entrevistados afirmarem que sabiam que alguns materiais farmacêuticos e cosméticos são tratados com radiação ionizante (FIG.26), apenas $26 \%$ deles tinham conhecimento sobre esse tratamento quando aplicado a alimentos (FIG.27).

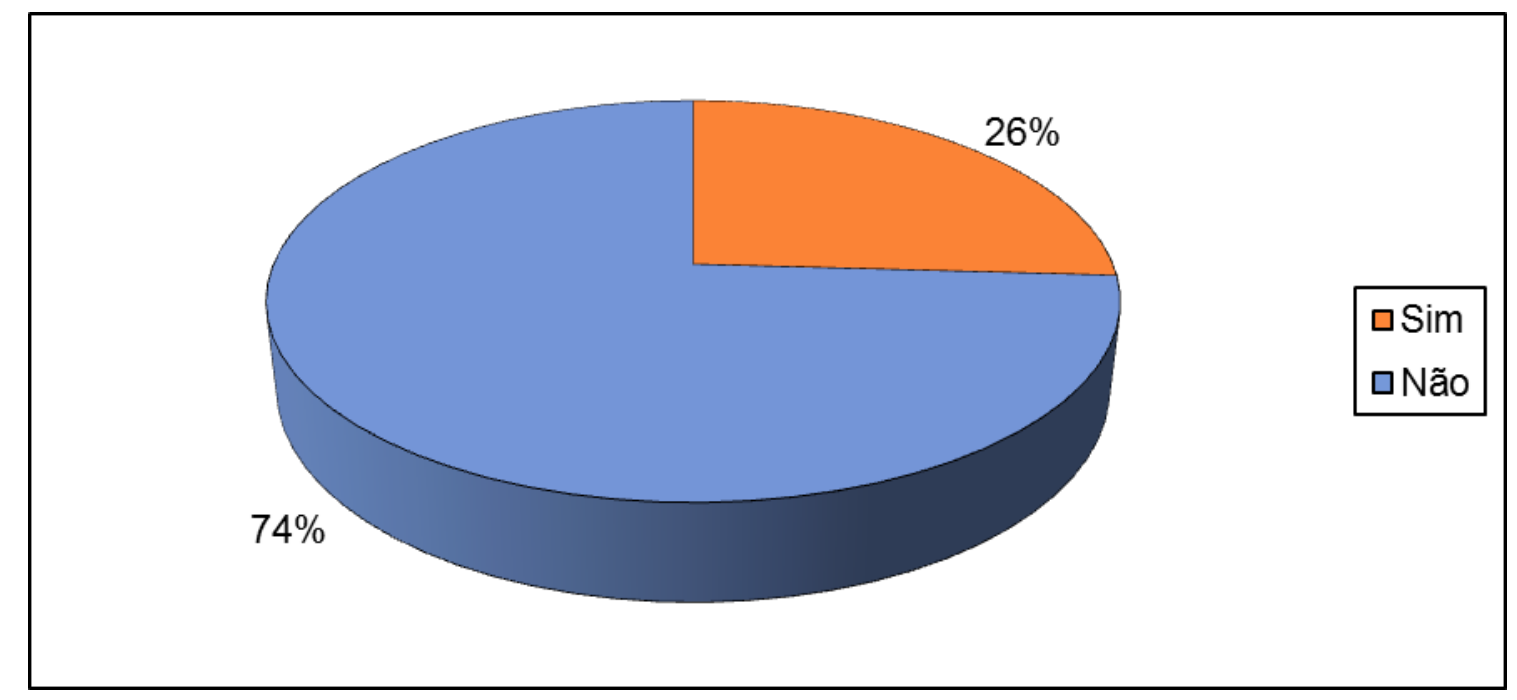

FIGURA 27 - Você sabia que uma das aplicações da energia nuclear é a irradiação de alimentos?

Como já mencionado anteriormente, a irradiação de alimentos, muito mais do que outros métodos de conservação de alimentos, precisou vencer as barreiras criadas por informações errôneas, prejudiciais, leis altamente restritivas e várias medidas regulatórias que, até os dias de hoje, vêm impedindo o uso irrestrito desta tecnologia (Diehl, 2002).

As pesquisas sugerem que as pessoas tendem a não estarem familiarizados com a irradiação de alimentos, mas a irradiação de alimentos já é permitida internacionalmente, por vários países. (Frewer et al., 2011).

Em relação à preocupação com os alimentos que consomem, verificouse que $94 \%$ dos consumidores entrevistados possuem esta preocupação, mas percebe-se que, mesmo sendo um público com nível de instrução elevado 
(FIG.22), 6\% dos consumidores não se preocupam com a qualidade do alimento que consomem (FIG.28).

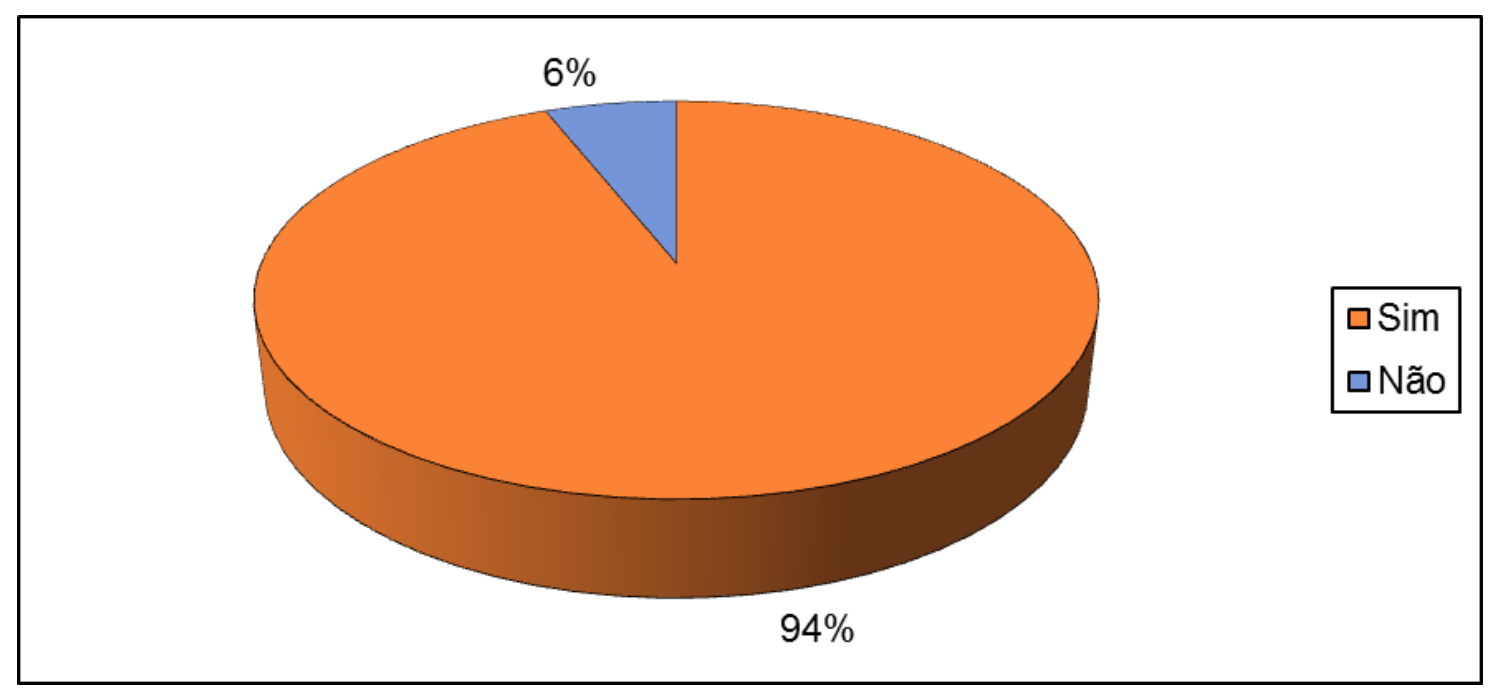

FIGURA 28 - Você se preocupa com a qualidade dos alimentos que consome?

$\mathrm{Na}$ questão 13 (FIG.29), o interesse era saber se os consumidores acreditavam que a irradiação de alimentos poderia produzir toxinas prejudiciais à saúde, ou se a irradiação acarretaria a perda de nutrientes existentes nos alimentos.

Como já visto na FIG.28, 94\% dos consumidores está preocupado com a qualidade dos alimentos que consome, mas se compararmos com as informações da FIG.27, 74\% dos entrevistados não possuía nenhum tipo de conhecimento sobre a irradiação de alimentos.

O fato de o termo toxina ter sido usado de modo geral, sem uma explicação mais detalhada, indica que os consumidores não possuem conhecimento sobre o assunto e de acordo com a FIG.29, 67\% dos entrevistados responderem que acreditam que a irradiação de alimentos produz toxinas ou acarreta a perda de nutrientes, e apenas 33\% responderam que não acreditam. 


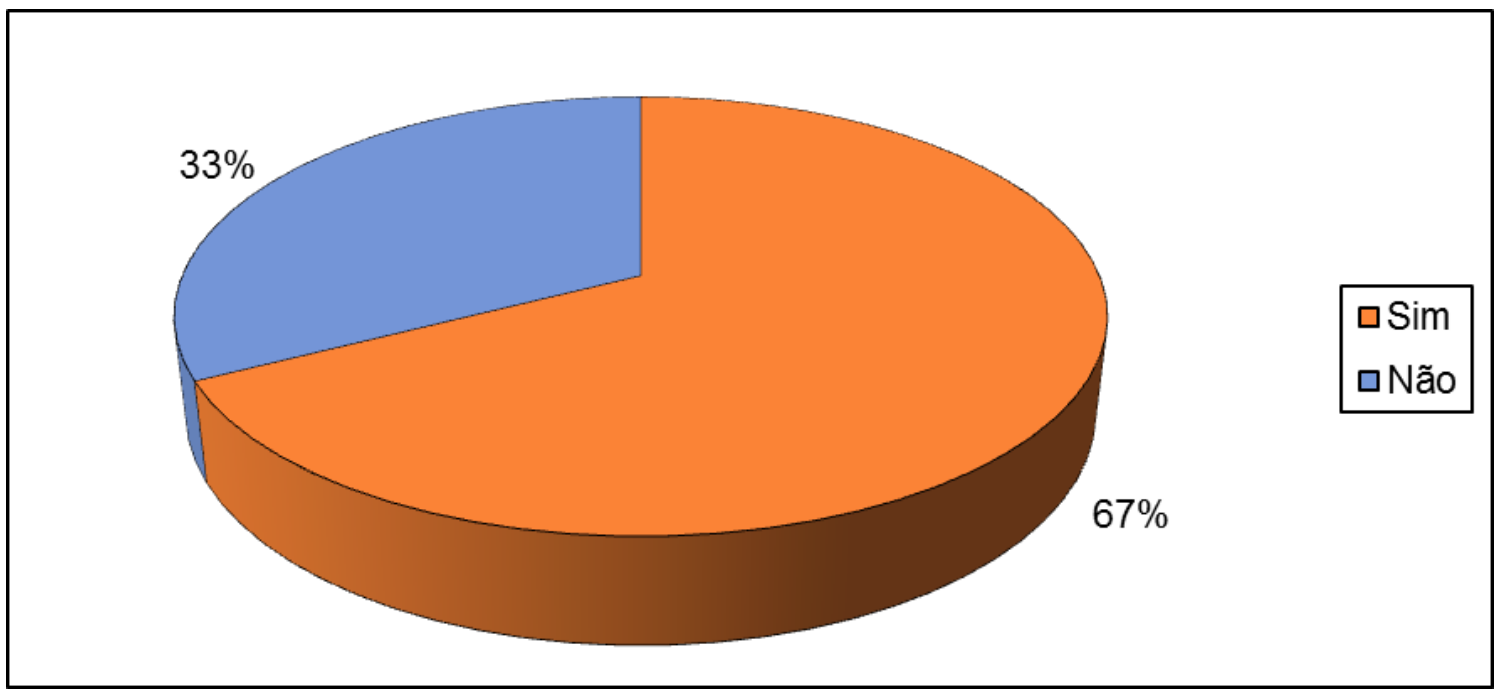

FIGURA 29 - Você acredita que a irradiação produz toxinas nos alimentos ou acarreta perda de nutrientes?

Quando questionados sobre o consumo de alimentos irradiados, 69\% dos consumidores entrevistados afirmaram que não os consumiriam e apenas $31 \%$ disseram que sim, consumiriam (FIG.30), o que é totalmente coerente com a FIG. 25, já que $66 \%$ dos entrevistados disseram que possuem uma impressão ruim da energia nuclear e apenas 34\% disseram possuírem uma boa impressão.

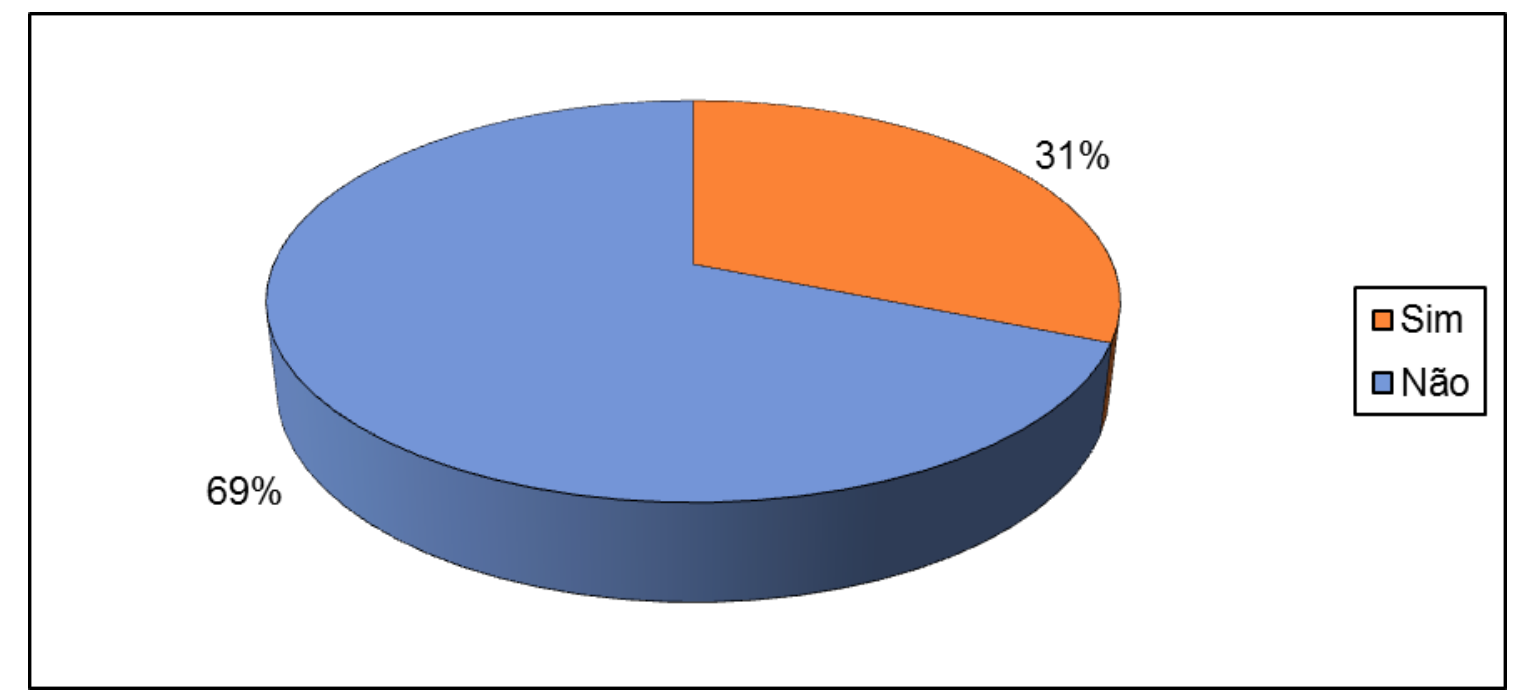

FIGURA 30 - Você consumiria alimentos irradiados?

A partir deste momento, foram recolhidas as partes I e II do questionário e, em seguida, os entrevistados passaram a assistir a um filme explicativo sobre os trabalhos do Instituto de Pesquisas Energéticas e Nucleares (IPEN) e a irradiação de alimentos, especificamente. Em nenhum momento, foram 
respondidas questões orais. Ao término do filme, foi entregue aos entrevistados a parte III de questionário.

\subsection{3 - Análise da intenção de compra de alimentos irradiados após os esclarecimentos}

Nesta terceira e última parte da pesquisa, os alunos passaram a responder as questões de 15 a 20 do questionário que diziam respeito à intenção de compra de alimentos irradiados após os esclarecimentos, mas mesmo assim não foi respondida nenhuma pergunta sobre o assunto. A TAB.10 apresenta os resultados encontrados.

TABELA 10 - Informações sobre a intenção de compra de alimentos irradiados após esclarecimentos

\begin{tabular}{l|c|c}
\hline Informações & $\mathbf{n}$ & $\%$ \\
\hline As explicações sobre as aplicações da energia nuclear foram esclarecedoras? \\
\hline Sim & 463 & 70 \\
Sim, mas insuficientes & 190 & 29 \\
Não & 11 & 2 \\
\hline Os esclarecimentos sobre a irradiação de alimentos foram importantes para você? \\
\hline Sim & 640 & 96 \\
Não & 24 & 4 \\
\hline
\end{tabular}

Depois dos esclarecimentos sobre a irradiação de alimentos, você compraria alimentos irradiados?

\begin{tabular}{l|l|l}
\hline Sim & 536 & 81 \\
Não & 128 & 19 \\
\hline
\end{tabular}

Em se tratando da segurança alimentar, você estaria disposto a pagar a mais por essa segurança?

\begin{tabular}{l|c|c}
\hline Sim & 412 & 62 \\
Não & 252 & 38 \\
\hline O preço do alimento irradiado influenciaria na sua decisão de compra? & \\
\hline Sim & 345 & 52 \\
Não & 319 & 48 \\
\hline
\end{tabular}


(continuação)

TABELA 10 - Informações sobre a intenção de compra de alimentos irradiados após esclarecimentos

\begin{tabular}{l|c|c}
\hline Informações & \multicolumn{2}{c}{$\mathbf{n}$} \\
\hline Sabendo que a irradiação de alimentos aumenta a segurança alimentar, quanto \\
você estaria disposto a pagar a mais por essa segurança? \\
\hline de 0\% a 5\% & 211 & 32 \\
de 5\% a 10\% & 160 & 24 \\
de 10\% a 20\% & 72 & 11 \\
mais de 20\% & 56 & 8 \\
não estou disposto a pagar & 165 & 25 \\
\hline
\end{tabular}

Fonte - Centro Universitário Fundação Santo André, 2011.

Segundo Francisco et al. (2007), observando-se a falta de informação do consumidor, verifica-se que os mesmos estão preocupados e cada vez mais interessados em saber a respeito da qualidade dos alimentos que estão consumindo, desde a data de validade até os riscos de intoxicação alimentar. Antigamente, o consumidor estava acostumado a comprar os alimentos apenas observando a sua aparência, mas atualmente, está cada vez mais interessado nos benefícios trazidos pelas novas tecnologias.

O principal objetivo da irradiação de alimentos é oferecer aos consumidores alimentos com melhor qualidade e higiene, mantendo sempre as suas propriedades nutricionais. A aceitação de novas tecnologias no processamento de alimentos está diretamente relacionada à credibilidade e confiança nas informações recebidas. Quando devidamente informados sobre o que é, para que serve e quais os benefícios da tecnologia de irradiação de alimentos, grande parte dos consumidores passa a reagir de forma positiva (Frewer et. al., 2011).

Questionados se as explicações sobre as aplicações da energia nuclear foram esclarecedoras, $70 \%$ dos consumidores entrevistados disseram que sim, $28 \%$ disseram que sim, mas que as informações não foram suficientemente esclarecedoras, restando algumas dúvidas e $2 \%$ afirmaram que 
as explicações não foram suficientes (FIG.31).

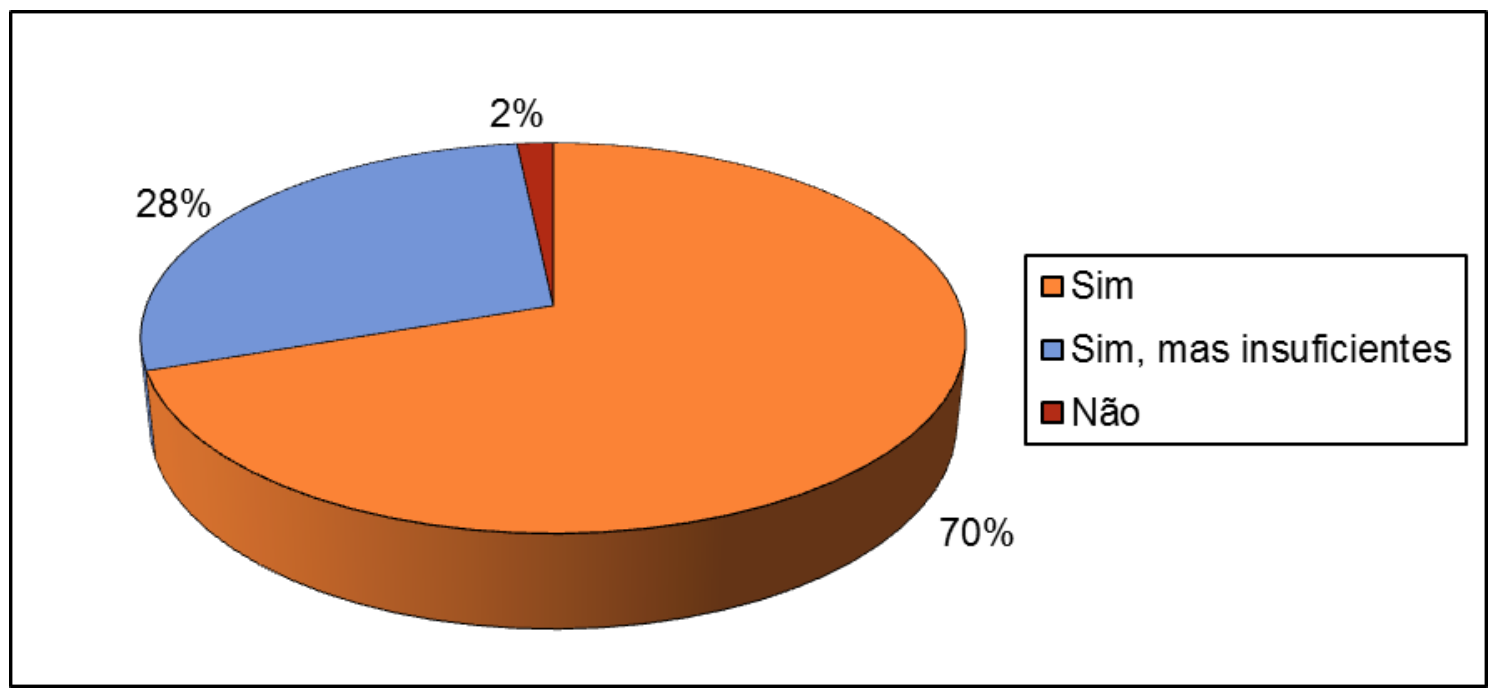

FIGURA 31 - As explicações sobre as aplicações da energia nuclear foram esclarecedoras?

Na questão 16 (FIG.32), o interesse era saber se os esclarecimentos sobre a irradiação de alimentos, apresentados no filme, foram importantes para cada um dos consumidores, já que, de acordo com a FIG.31, 2\% dos consumidores não acharam as explicações esclarecedoras. Observamos que $96 \%$ dos entrevistados afirmaram que os esclarecimentos foram importantes e apenas $4 \%$ afirmaram que não (FIG.32).

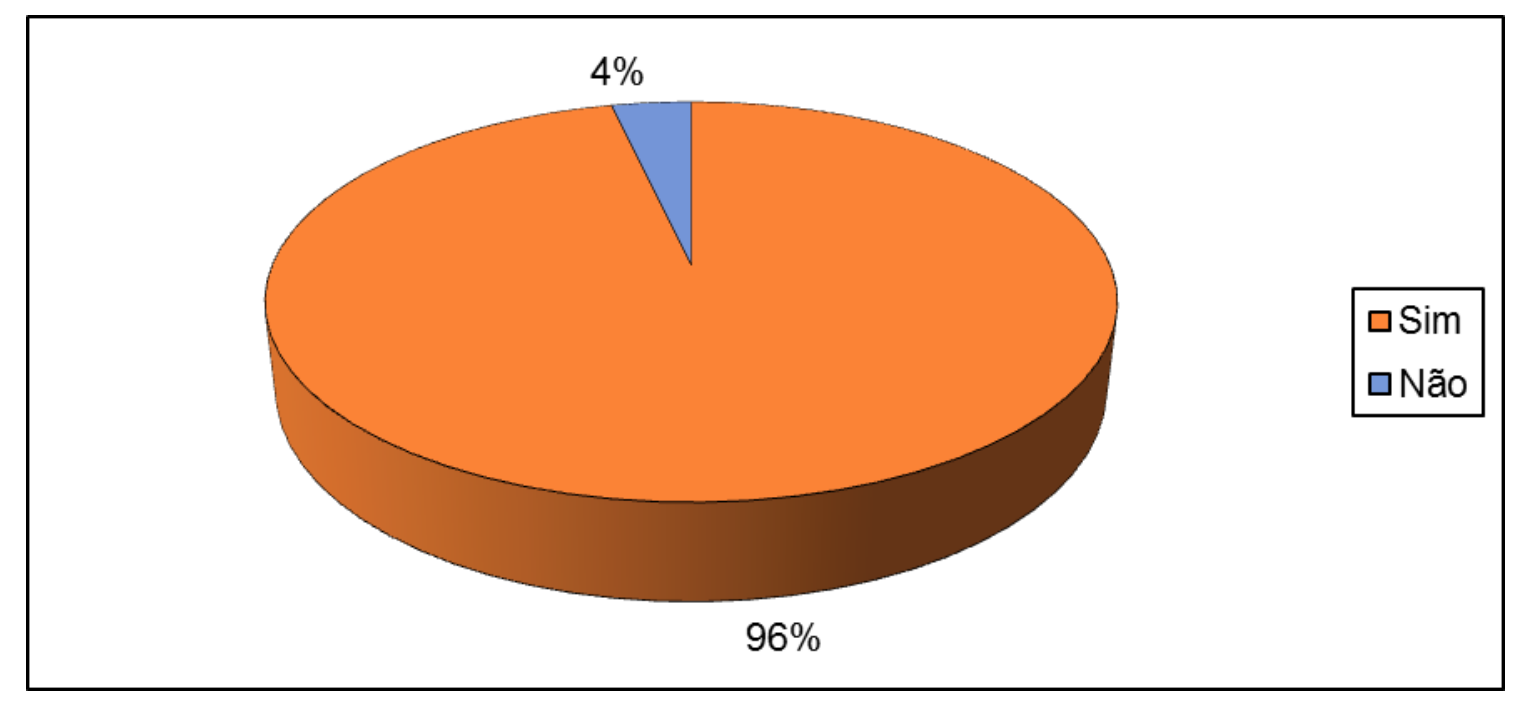

FIGURA 32 - Os esclarecimentos sobre a irradiação de alimentos foram importantes para você?

Os estudos e testes feitos por Crowley et al. (2002) demonstraram 
que, quando os consumidores recebem esclarecimentos sobre os benefícios da irradiação de alimentos e sobre os riscos à saúde que o alimento não tratado oferece, os consumidores aceitam os alimentos irradiados. Em sua pesquisa sobre o conhecimento e a intenção do compra dos alimentos irradiados, $85 \%$ dos consumidores já havia ouvido falar em irradiação de alimentos e 70\% deles demonstraram a intenção de comprar esses alimentos. Tudo indica que existe uma ligação positiva entre ter consciência sobre o assunto e a predisposição para comprar os alimentos irradiados, pois quando o consumidor é esclarecido sobre os benefícios advindos do tratamento do alimento por irradiação opta pela compra do alimento irradiado.

Bruhn (1995b) considera que os estudos sobre atitudes e testes de compra de alimentos irradiados demonstram que os consumidores os aceitam quando têm essa opção, mas que seus conhecimentos sobre essa tecnologia ainda são limitados.

Quando questionados se comprariam alimentos irradiados, $81 \%$ dos entrevistados afirmaram que sim e 19\% afirmaram que não (FIG.33), uma diferença significativa entre a intenção de consumir alimentos irradiados apresentado na FIG.30, onde apenas 31\% consumiriam este tipo de alimento e o apresentado na FIG.33.

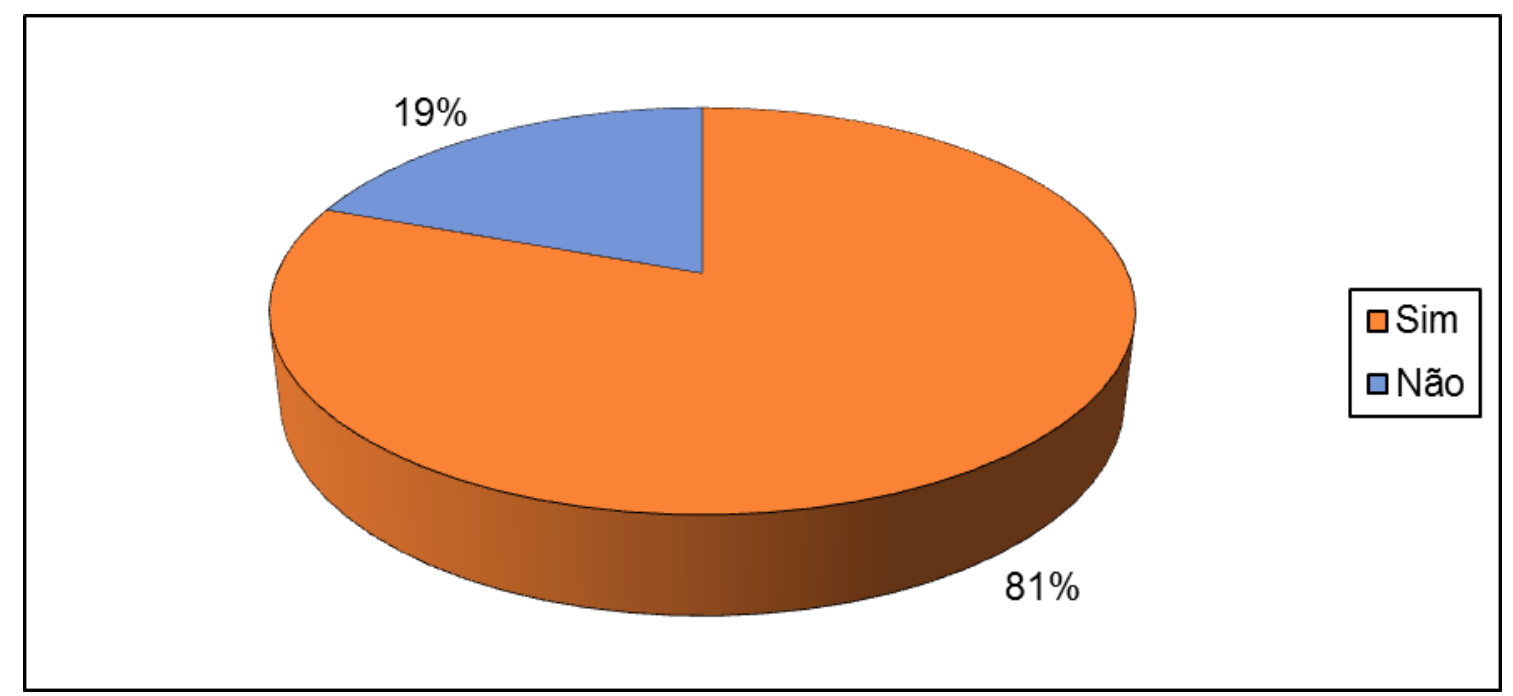

FIGURA 33 - Depois dos esclarecimentos sobre a irradiação de alimentos, você compraria alimentos irradiados? 
Em relação à segurança alimentar, os consumidores desejam ser informados sobre tudo que estão comendo. Como o tratamento do alimento pela radiação ionizante traz benefícios para os consumidores, em termos de durabilidade, conveniência, praticidade e melhor higiene dos alimentos, segundo Schultz et al. (1989) e Resurreccion et al. (1995), alguns consumidores já consideram a sua compra, e de acordo com as pesquisas já apresentadas observa-se que, caso os consumidores percebam os benefícios advindos do tratamento pela irradiação, eles preferirão os alimentos irradiados.

Segundo Polhman et al. (1994) e Hashim et al. (1996), várias pesquisas vêm sendo realizadas para estudar a influência da informação sobre esta tecnologia, o nível de conhecimento e a aceitabilidade dos produtos irradiados.

A FIG.34 mostra que $62 \%$ dos consumidores entrevistados estão predispostos a pagar a mais pela segurança alimentar e que $38 \%$ possuem esta predisposição.

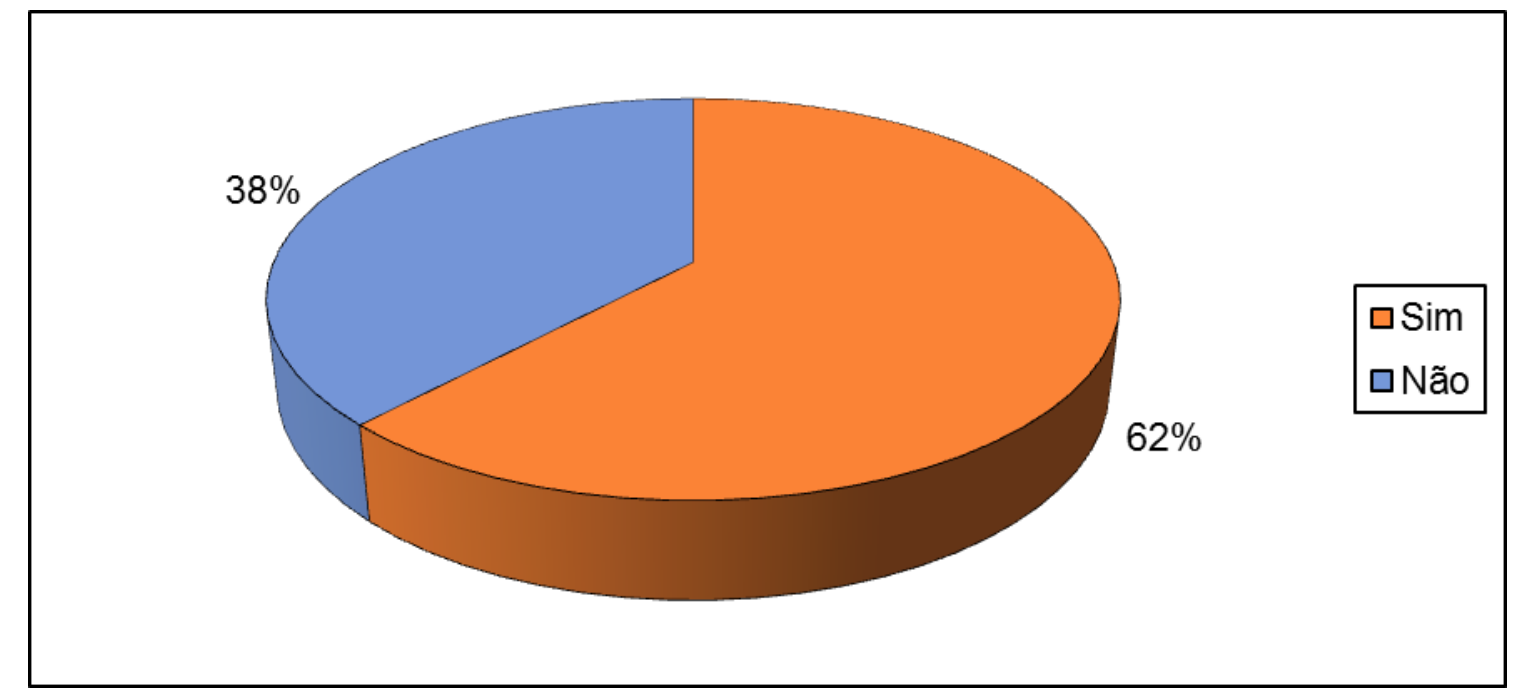

FIGURA 34 - Em se tratando da segurança alimentar, você estaria disposto a pagar a mais por essa segurança?

Em relação à questão 19, quando os consumidores foram questionados, se o preço do alimento irradiado influenciaria na decisão de compra, 52\% responderam que sim e $48 \%$ responderam que não (FIG.35). Isto 
pode ser explicado pela FIG. 23, já que 59\% dos consumidores entrevistados pertencem à faixa salarial de até $R \$ 2000,00$ e $32 \%$ recebem mais de $R \$$ 2000,00 .

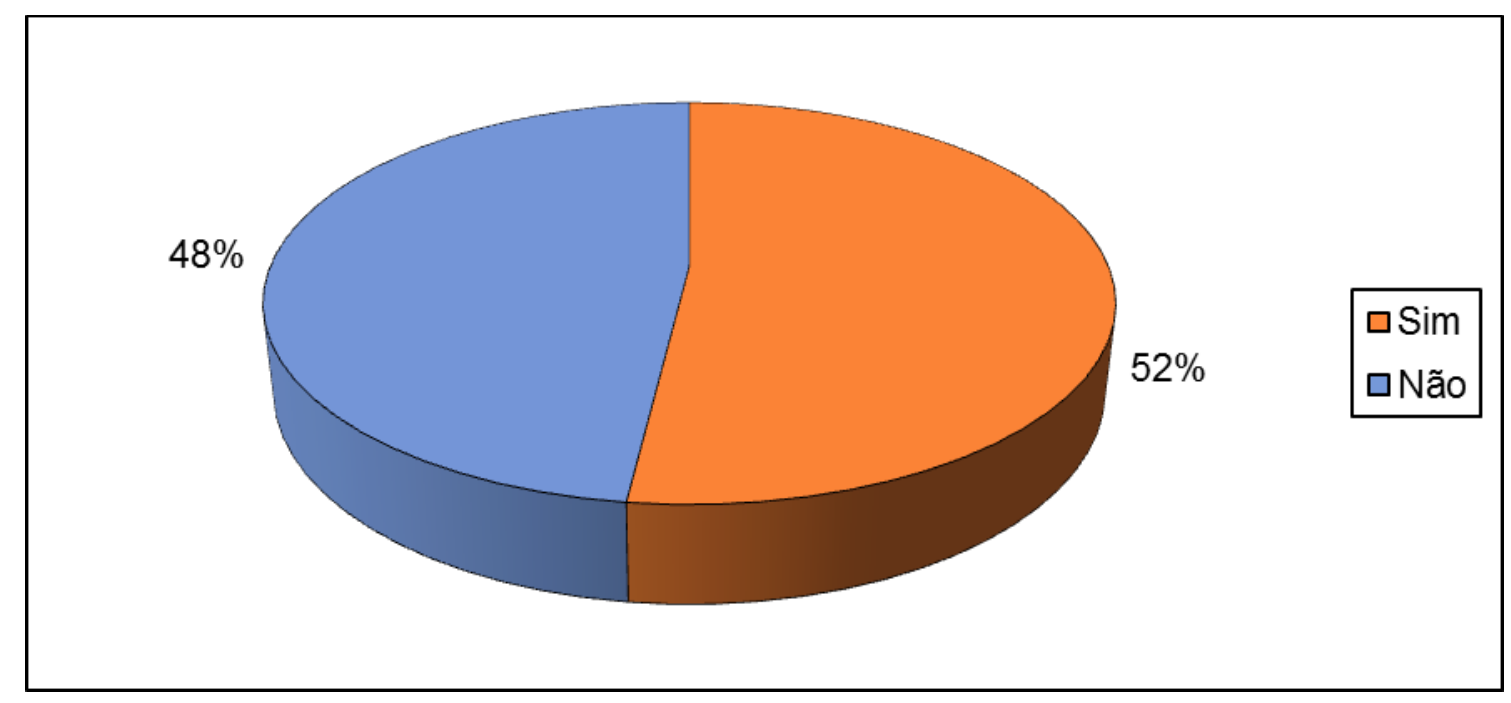

FIGURA 35 - O preço do alimento irradiado influenciaria na sua decisão de compra?

Como apresentado anteriormente, na pesquisa realizada por Gunes \& Tekin (2006) em Istambul, na Turquia, chegou-se à conclusão de que a aceitação do alimento irradiado pode aumentar, mais ainda, se o preço desses alimentos for igual ao preço dos alimentos não irradiados.

Segundo Terry \& Tabor (1998), análises econômicas indicam que o preço tem influência na intenção de compra. Nessas análises, os grupos em que a renda era menor, foram sensíveis ao preço, entre as pessoas com maior renda, mais da metade foram propensos a comprar alimentos irradiados com menor, igual ou preço mais elevado do que os preços dos alimentos não irradiados.

Esta última questão avalia quanto o consumidor entrevistado está disposto a pagar a mais pelo alimento irradiado, já que ele já está consciente dos benefícios para a segurança alimentar que este tipo de tratamento apresenta.

Verificou-se que $32 \%$ estão dispostos a pagar até $5 \%$ a mais pelo alimento irradiado, $24 \%$ estão dispostos a pagar entre $5 \%$ e $10 \%$ a mais, $11 \%$ estão dispostos a pagar entre $10 \%$ e $20 \%$ a mais, $8 \%$ estão dispostos a pagar 
mais de $20 \%$ por este alimento e que $25 \%$ não estão dispostos a pagar pelo alimento irradiado (FIG.36).

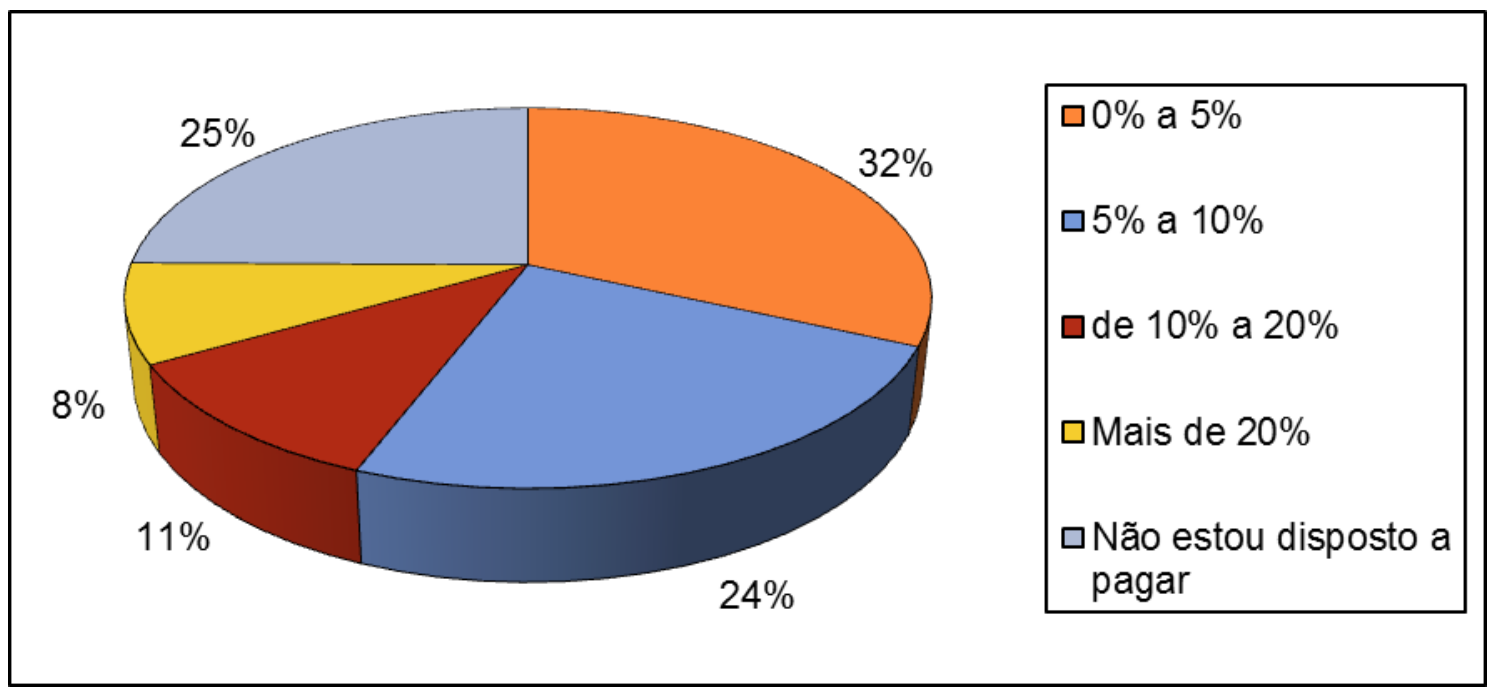

FIGURA 36 - Sabendo que a irradiação de alimentos aumenta a segurança alimentar, quanto você estaria disposto a pagar a mais por essa segurança?

Comparando-se as respostas obtidas nesta questão (FIG.36) e as obtidas na questão 8 (FIG.24), verificou-se que:

- $13 \%$ dos entrevistados pagariam mais de $20 \%$ pelo alimento irradiado (FIG.36) e $8 \%$ possuem renda acima de $\mathrm{R} \$ 6000,00$ (FIG.24);

- $11 \%$ pagariam de $10 \%$ a $20 \%$ a mais (FIG.36) e $14 \%$ possuem renda entre $\mathrm{R} \$ 4000,00$ e $\mathrm{R} \$ 6000,00$ (FIG. 24);

- $24 \%$ pagariam de $5 \%$ a $10 \%$ a mais pelo alimento irradiado (FIG.36) e 40\% possuem renda entre $R \$ 2000,00$ e $R \$ 4000,00$ (FIG. 24);

- $32 \%$ de consumidores que pagariam até $5 \%$ a mais pelo alimento irradiado (FIG.36) e 33\% dos entrevistados com renda inferior a $\mathrm{R} \$$ 2000,00 ou sem rendimentos (FIG.24). 
De acordo com FIG.36, 25\% dos consumidores não pagariam pelo alimento irradiado, mas é necessário que se entenda que a vida útil do alimento deve ser prolongada, de forma a diminuírem-se os problemas de abastecimento irregular motivados pela entressafra e perdas na pós-colheita.

Em relação ao mercado brasileiro, já sabemos que os alimentos são um elemento importante na nossa balança comercial e que a escolha pelos alimentos irradiados envolve também a questão financeira e, portanto, de acordo com nossa pesquisa, podemos afirmar que $75 \%$ dos consumidores entrevistados aceitam pagar, no mínimo, 5\% a mais pelo alimento irradiado. 


\section{5 - CONCLUSÃO}

Concluiu-se, por meio do estudo feito em pesquisas bibliográficas, sobre a viabilidade econômica, que o processo de irradiação de alimentos, apesar de possuir um investimento relativamente alto, traz retorno rápido para um processo contínuo.

Para a irradiação comercial, usando-se um irradiador de Cobalto 60 $\left({ }^{60} \mathrm{Co}\right)$ tem-se que:

- usando-se doses baixas (até $1 \mathrm{kGy}$ ), o custo varia entre $\mathrm{R} \$ 20,00$ e $R \$ 30,00$ por tonelada, o que significa um acréscimo entre $R \$ 0,02$ a $R \$ 0,03$ por quilograma de alimento;

- usando-se doses altas (mais de $10 \mathrm{kGy}$ ), o custo varia entre $\mathrm{R} \$$ 200,00 e $R \$ 500,00$ por tonelada, o que significa um acréscimo de $R \$ 0,20$ a $R \$ 0,50$ por quilograma de alimento.

Para a irradiação comercial, usando-se um acelerador de partículas tem-se:

- um custo de $R \$ 30,00$ a $R \$ 120,00$ por tonelada, isto é, de $R \$ 0,03$ a $R \$ 0,12$ por quilograma de alimento.

A tendência é a difusão da tecnologia, principalmente nos países que possuem uma economia agrária importante. Como o Brasil é hoje, um grande produtor e exportador de alimentos, deveria estar preparado para os impactos das novas tecnologias. Se fossem feitos mais investimentos nesta tecnologia, seria possível adquirir formas seguras e versáteis para obter alimentos de boa qualidade, reduzindo as perdas pós-colheita e os problemas da entressafra. 
A pesquisa realizada indica que os consumidores estão cada vez mais interessados em uma alimentação saudável. Preocupados com os métodos alternativos, estão cada vez mais exigentes em relação às novas tecnologias utilizadas no tratamento dos alimentos que estão consumindo. Concluiu-se que a maioria dos consumidores, se informada sobre o assunto, mostra-se disposta a arcar com o custo do alimento irradiado. Assim:

- $32 \%$ estão dispostos a pagar até $5 \%$ a mais pelo alimento irradiado;

- $24 \%$ estão dispostos a pagar entre $5 \%$ e $10 \%$ a mais;

- $11 \%$ estão dispostos a pagar entre $10 \%$ e $20 \%$ a mais;

- $8 \%$ estão dispostos a pagar mais de $20 \%$ por este alimento;

- $25 \%$ dos consumidores não estão dispostos a pagar pelo alimento irradiado.

Como o principal objetivo do uso da radiação ionizante é oferecer, aos consumidores, produtos de melhor qualidade, higiene e durabilidade, e como qualquer método de tratamento irá acrescentar custos aos alimentos, os produtores e investidores podem ser favorecidos implantando uma tecnologia de menor custo, como é o caso dos aceleradores de partículas, já que o acréscimo ao consumidor é quase o mesmo, em qualquer um dos dois tipos de irradiadores.

As respostas obtidas na pesquisa indicam que, quanto maior o poder aquisitivo, maior a predisposição em arcar com o acréscimo ao custo do alimento irradiado e que $75 \%$ dos consumidores entrevistados aceitam pagar mais por este alimento; portanto, no momento em que o consumidor já estiver consciente do preço, a rotulagem dos alimentos irradiados deve proporcionar a oportunidade de decidir se querem ou não adquirir estes produtos. 
ANEXOS

\section{ANEXO A - QUESTIONÁRIO}

Título da pesquisa: PREDISPOSIÇÃO DO CONSUMIDOR EM ARCAR COM O CUSTO DO ALIMENTO PROCESSADO POR RADIAÇÃO IONIZANTE

PARTE I - Caracterização socioeconômica e demográfica

Número do entrevistado:

Local da entrevista:

1) Município de residência:

2) Gênero:
( ) masculino
( ) feminino

3) Idade: anos

4) Estado civil:

( ) solteiro(a)

( ) casado(a)

( ) divorciado(a)

( ) separado(a)

( ) relação estável

( ) viúvo(a)

5) Número de filhos(as):

( ) nenhum

( ) 01

( ) 02

( ) 03

( ) mais que 03 
6) Grau de escolaridade:

( ) superior completo

( ) superior incompleto

7) Qual a faixa salarial pessoal mensal?

( ) até $R \$ 1000,00$

( ) entre $R \$ 1000,00$ e $R \$ 2000,00$

( ) entre $R \$ 2000,00$ e $R \$ 4000,00$

( ) entre $R \$ 4000,00$ e $R \$ 6000,00$

( ) mais de $R \$ 6000,00$

( ) sem rendimento

( ) não sabe

( ) não quer responder

8) Qual a faixa salarial familiar mensal?

( ) até $R \$ 1000,00$

( ) entre $R \$ 1000,00$ e $R \$ 2000,00$

( ) entre $R \$ 2000,00$ e $R \$ 4000,00$

( ) entre $R \$ 4000,00$ e $R \$ 6000,00$

( ) mais de $R \$ 6000,00$

( ) sem rendimento

( ) não sabe

( ) não quer responder 
PARTE II - Informações sobre as aplicações da energia nuclear sem esclarecimentos prévios.

9) Quando você ouve falar em energia nuclear, a impressão que você tem é:

$$
\text { ( ) boa ( ) ruim }
$$

10) Você sabia que materiais farmacêuticos (fraldas descartáveis, gazes, seringas, agulhas, etc) e alguns cosméticos disponíveis no mercado são esterilizados por meio da irradiação?
( ) $\sin$
( ) não

11) Você sabia que uma das aplicações da energia nuclear é a irradiação de alimentos?
( ) $\operatorname{sim}$
( ) não

12) Você se preocupa com a qualidade dos alimentos que consome?

( ) sim ( ) não

13) Você acredita que a irradiação produz toxinas nos alimentos ou acarreta perda de nutrientes?

( ) $\operatorname{sim}$ ( ) não

14) Você consumiria alimentos irradiados?

( ) $\operatorname{sim}$ ( ) não 
Número do entrevistado:

PARTE III - Informações sobre a intenção de compra de alimentos irradiados após esclarecimentos.

15) As explicações sobre as aplicações da energia nuclear foram esclarecedoras?
( ) $\sin$
( ) sim, mas insuficientes
( ) não

16) Os esclarecimentos sobre a irradiação de alimentos foram importantes para você?
( ) $\sin$
( ) não

17) Depois dos esclarecimentos sobre a irradiação de alimentos, você compraria alimentos irradiados?
( ) $\operatorname{sim}$ ( ) não

18) Em se tratando da segurança alimentar, você estaria disposto a pagar a mais por essa segurança?
( ) $\operatorname{sim}$ ( ) não

19) O preço do alimento irradiado influenciaria na sua decisão de compra?
( ) $\operatorname{sim}$ ( ) não

20) Sabendo que a irradiação de alimentos aumenta a segurança alimentar, quanto você estaria disposto a pagar a mais por essa segurança?

( ) de $0 \%$ a $5 \%$

( ) de $5 \%$ a $10 \%$

( ) de $10 \%$ a $20 \%$

( ) mais de $20 \%$

( ) não estou disposto a pagar

Obrigada pela sua colaboração! Pesquisadora: Eliana Borba Cattaruzzi 


\section{REFERÊNCIAS BIBLIOGRÁFICAS}

ACELÉTRON - Acelétron Irradiação Comercial. Disponível em: http://www.aceletron.com.br. Acesso em: 22 nov. 2011.

ALKAN, H.; YALÇINTAS, M. Food Irradiation Technology, Legislation and Application in Turkey. In: INTERNATIONAL CONGRESS ON FOOD TECHNOLOGY, 1, nov. 03-06, 2010, Antalya, Turkey. Proceedings... Turkey, 2010.

ANVISA - Agência Nacional de Vigilância Sanitária. Disponível em: http://www.portal.anvisa.gov.br. Acesso em 04 fev. 2011.

AZEREDO, H. M. C. Fundamentos de estabilidade de alimentos. Fortaleza: Embrapa Agroindústria Tropical, 2004. 195p.

BOAVENTURA, M. Irradiação. Minas Faz Ciência. Minas Gerais, n. 21, dez. 2004/maio 2005. Disponível em: http://revista.fapemig.br/materia.php/id=220. Acesso em: 03 ago. 2010.

BRASIL. Ministério da Agricultura, Pecuária e Abastecimento, Agência Nacional de Vigilância Sanitária. Resolução no 21, de 26 de janeiro 2001. Relatório técnico para a irradiação de alimentos. Disponível em: http://anvisa.gov.br/legis/resol/21 01rdc.htm. Acesso em: 28 abr. 2009.

BRASIL. Ministério da Agricultura, Pecuária e Abastecimento, Agência Nacional de Vigilância Sanitária. Resolução no 9, de 24 de fevereiro de 2011. Disponível em: http://www.agricultura.gov.br. Acesso em 12 mar. 2011.

BRASIL. Ministério da Saúde. Decreto-Lei no 72.718, de 29 de agosto de 1973. Estabelece normas gerais sobre irradiação de alimentos. Disponível em: http://www.anvisa.gov.br. Acesso em: 28 abr. 2009.

BRASIL. Ministério da Saúde. Decreto-Lei no 986, de 21 de outubro de 1969. Institui normas básicas sobre alimentos. Disponível em: http://www.anvisa.gov.br. Acesso em: 28 abr. 2009.

BRASIL. Ministério da Saúde. Portaria o 30 - DINAL/MS, de 25 de setembro de 1989. Especifica os alimentos com autorização para o uso de tratamento por irradiação. Disponível em: http://www.anvisa.gov.br. Acesso em: 28 abr. 2009.

BRASIL. Ministério da Saúde. Portaria no 9 - DINAL/MS, de 08 de março de 1985. Aprova normas gerais para a irradiação de alimentos e aprova a relação de alimentos cuja irradiação é autorizada. Disponível em: http://www.anvisa.gov.br.Acesso em: 28 abr. 2009. 
BRUHN, C. M. Strategies for communicating the facts on food irradiation to consumers. $\boldsymbol{J}$. Food Prot., v. 58, n. 1, p. 213-216, 1995a.

BRUHN, C. M. Consumer Attitudes and Market response to Irradiated Food. J. Food Prot., v. 58, n. 2, p. 175-181, 1995b.

BRUHN, C. M.; SCHULTZ, H. G. Consumer awareness and outlook for acceptance of food irradiation. Food Technol., Chicago, v. 43, n. 7, p. 93-94, 97, 1989.

CASSAROTTO FILHO, N.; KOPITTKE, B. H. Análise de Investimentos. $11^{\underline{a}}$ ed. São Paulo. Atlas, 2002.

CDTN - Centro de Desenvolvimento da Tecnologia Nuclear. Disponível em http://www.cdtn.br. Acesso em: 14 out. 2011.

CENA/USP - Centro de Energia Nuclear na Agricultura, Campus "Luiz Queiroz" Irradiação de alimentos. Disponível em: http://www.cena.usp.br/irradiacao/index.asp. Acesso em: 05 fev. 2012a.

CENA/USP - Centro de Energia Nuclear na Agricultura, Campus "Luiz Queiroz" Equipamentos utilizados para irradiação de alimentos e/ou outros materiais. Disponível em: http://www.cena.usp.br/irradiacao/equipamentos.htm. Acesso em: 05 fev. 2012b.

CENA/USP - Centro de Energia Nuclear na Agricultura, Campus "Luiz Queiroz" Conservação de alimentos. Disponível em: http://www.cena.usp.br/irradiacao/cons calor.html. Acesso em: 05 fev. 2012c.

CENA/USP - Centro de Energia Nuclear na Agricultura, Campus "Luiz Queiroz" Conservação de alimentos. Disponível em: http://www.cena.usp.br/irradiacao/cons frio.html. Acesso em: 05 fev. 2012d.

CENA/USP - Centro de Energia Nuclear na Agricultura, Campus "Luiz Queiroz" Conservação de alimentos. Disponível em: http://www.cena.usp.br/irradiação/cons irrad.html. Acesso em: 05 fev. 2012e.

CGEE - Centro de Gestão e Estudos Estratégicos. Estudo da Cadeia de Suprimento do Programa Nuclear Brasileiro. Relatório Parcial: Irradiadores e Aplicações. Panorama Análise de oportunidades e desafios para o segmento de Irradiadores e Aplicações na Cadeia Produtiva do Agronegócio. Brasília, nov. 2010.

CHEN, Q. Irradiation of hot peppers to improve their hygienic quality. In: ASIAN REGIONAL COOPERATIVE PROJECT ON FOOD. IRRADIATION TECHNOLOGY TRANSFER, Vienna: IAEA, 1992. p. 37-49.

CNEN - Comissão Nacional de Energia Nuclear. Radiações lonizantes e a vida. Disponível em: http://www.cnen.gov.br/ensino/apostilas/rad-ion.pdf. Acesso em: 15 jun. 2010. 
COCHRAN, W. G. Sampling techniques. 3.ed. New York: J.Wiley. 1977.

CODEX ALIMENTARIUS. Higiene dos Alimentos. Textos Básicos. ANVISA. Disponível em: www.anvisa.gov.br/divulga/public/alimentos/codex alimentarius.pdf. Acesso em: 05 fev. 2010.

CROWLEY, M. L.; GABOURY, D. J.; WITT, D. Chef's attitudes in North-Eastern U.S. toward irradiation beef, Olestra, rBST and genetically engineered tomatoes. Food Service Tecnology, v. 2. P. 173-181, 2002.

CUNNIGHAN. M. E. A mobile Food Irradiation Facility. University of Tennessee Honors Thesis Projects, 2009. Disponível em: http://trace.tennessee.edu. Acesso em: 13 set. 2011.

CURZIO, O. A.; CROCI, C. A. Studies of Pre-Commercial Scale Irradiation of Onions and Garlic to Control Sprouting, Final report, research Contract no 4453/R2/RB, Universidad Nacional del Sur, Bahía Blanca, Argentina (1990).

CURZIO, O. A.; CROCI, C. A.; URIOSTE, A. M. Marketing trials with irradiated onions and garlic in Argentina. Food Irrad. NewsI. v. 10, n. 1, p. 44-45, IAEA, Vienna, 1986.

DAVIES, A., TITTERINGTON, A. J., COCHRANE, C. Who buys organic food? A profile of the purchasers of organic food in Northern Ireland. British Food Journal, v. 97, n. 10, p. 17-23, 1995.

DELINCÉE, H. Detection of food treat with ionizing radiation. Trends Food Sci. Tech., v. 9, n. 2, p. 73-82, 1998.

DELINCÉE, H.; VILLAVICENCIO, A. L. C. H.; MANCINI-FILHO, J. Protein quality of irradiated Brazilian beans. Rad. Phys. Chem., v.52, n. 1-6, p. 43-48, 1998.

DIEHL, J. F., Food Irradiation: past, present and future. Rad. Phys. Chem., v. 63, p. 211 215, 2002.

EMBRARAD - Empresa Brasileira de Radiações. Disponível em: http://www.cbesa.com.br. Acesso em: 16 set. 2010.

FAN, X.; SOKORAL, K. J. B. Changes in volatile compounds of $\mathrm{Y}$-irradiated fresh cilantro leaves during cold storage. Journal of Agricultural and Food Chemistry v.50, p.76227626, 2002.

FAO - Food and Agricultural Organization. Disponível em: http://www.fao.org. Acesso em: 04 fev. 2010.

FAO. Food and Agricultural Organization. Post-harvest losses aggravate hunger: Improved technology and training show success in reducing losses. Disponível em: http://www.fao.org/news/story/en/item/36844/icode/. Acesso em: 15 fev. 2011. 
FARKAS, J. Irradiation for better foods. Trends Food Sci. Tech. v. 17, p. 148-152, 2006.

FDA - U.S. Food and Drugs Administration. Disponível em: http://www.fda.gov. Acesso em 04 fev. 2010.

FORD, N. J.; RENNIE, D. M. Consumer understanding of food irradiation. J. Consumer Studies Home Econ, v. 11, p. 305-320, 1987.

FOX, J. A. Influences on purchase of irradiated foods. Food Technology, v.56, n. 11, p. 34-37, 2002.

FOX, J. A.; OLSON, D. G. Market trials of irradiated chicken. Rad. Phys. Chem. v.52, n. 1, p. 63-66, 1998.

FRANÇA, H. Brasileiro ainda desconhece benefícios da irradiação de alimentos. Agência Brasil. Brasília, 5 maio, 2000. Disponível em: http://www.radiobras.gov.br. Acesso em: 13 ago. 2009.

FRANCISCO, D. C.; NASCIMENTO, V. P.; LOGUERCIO, A. P.;CAMARGO, L. Caracterização do consumidor de carne de frango da cidade de Porto Alegre. Ciência Rural. Santa Maria, v. 37, n. 1, p. 253-258, 2007.

FREITAS, P. A. P.; SOUZA, M.A.M.; SANTOS, E.A.; SANTANA, N.M.; OLIVEIRA, A.C.S.; TORRES, R.; CAMPOS, A.B.;SILVA, L.R.S.; PADILHA, M.R.F.; SHINOHARA, N.K.S.

Atitude dos consumidores recifenses em relação a alimentos irradiados. In: IX Jornada de Ensino, Pesquisa e Extensão - JEPEX 2009, Recife. Anais eletrônicos... Recife: UFRPE, 2009. Disponível em:

http://www.eventosufrpe.com.br/jepex2009/cd/lista area 14.htm Acesso em: 21 jan 2011.

FREWER, L. J.; BERGMANN, K.;BRENNAN, M.; LION, R.; MEERTENS, R.; ROWE, G.; SIEGRIST, M.; VEREIJKEN, C. Consumer response to novel agri-food technologies: Implications for predicting consumer acceptance of emerging food technologies. Trends in Food Science \& Technology, n. 22, p. 442-456, 2011.

FRIZZONE, J. A. Planejamento da irrigação: uma abordagem às decisões de investimento. Piracicaba: ESALQ/USP, 1999.

FUMENTO, M. Irradiation: a winning recipe for wholesome beef. Priorities, v. 6, n. 2, p. 37-39, 1994.

GHOBRIL, C. N. Gestão Tecnológica para instalação de um irradiador de alimentos no Vale do Ribeira. 2008. Tese (Doutorado) - IPEN, São Paulo.

GUNES, G.; TEKIN, M. D. Consumer awareness and acceptance of irradiated foods: Results of a survey conducted on Turkish consumers. Food Science and Technology, v. 39, n. 4, p. 443-447, 2006. 
HASHIM, I. B., RESURRECCION, A. V. A., McWATTERS, K. H. Consumer attitudes toward irradiated poultry. Food Technology, v. 50, n. 3, p. 77-80, 1996.

HAYES, D. J.; FARRAR, H. FAO/IAEA Mission Report, Commercial Application of Food Irradiation in Brazil, mar. 1996.

HENSON, S. Demand-side constraints on the introduction of new food technologies: the case of food irradiation. Food Policy, n. 20, p. 111-127, 1995.

HOBBS, B. C.; ROBERTS, D. Deterioração e Preservação. Toxinfecções e Controle Higiênico. São Paulo: Varela, p. 137-138, 1998.

HUFSCHMIDT, M. M.; JAMES, D. E. MEISTER, A. D. BOWER, B. F.;DIXON, J. A. Environment, natural systems and development. Baltimore: Johns Hopkins University Press, 1983.

IAEA. International Atomic Energy Agency. Disponível em: http://nucleus.iaea.org/FIFDB/Browse.aspx. Acesso em: 28 abr. 2012a.

IAEA. International Atomic Energy Agency. Disponível em: http://nucleus.iaea.org/FICDB/Browse.aspx. Acesso em: 28 abr. 2012b.

IAEA. International Atomic Energy Agency. Food irradiation combating bacteria around the world, Staff Report. Disponível em: www.iaea.org/newscenter/n ews/2009/foodirradiation.html. Acesso em: 15 fev. 2010a.

IAEA. International Atomic Energy Agency. Information from the International Atomic Energy Agency. Disponível em: http://www.iaea.org/nafa/d5/public/foodirradiation.pdf. Acesso em: 15 fev. 2010b.

IBGE. Instituto Brasileiro de Geografia e Estatística. Disponível em: http://www.ibge.gov.br. Acesso em: 12 fev. 2012.

ICGFI - International Consultative Group on Food Irradiation. Consumer Attitudes and Market response to Irradiated Food. Vienna, Áustria,1999a.

ICGFI - International Consultative Group on Food Irradiation. Facts about irradiation. Vienna, Áustria,1999b.

IPEN - Instituto de Pesquisas Energéticas e Nucleares. Disponível em: http://www.ipen.gov.br. Acesso em: 12 fev. 2012.

KURAMOTO, E. Os dividendos da Tecnologia Nuclear. Custo Brasil, n. 02, p.34-35. 2008. 
LAIZIER, J. Test market of irradiated strawberries in France. Food Irradiation Newsletter, n.112, p. 45-46, IAEA, Vienna, 1987.

LEAL, A. S. UFMG, CDTN E Funed pesquisam efeitos da irradiação de alimentos - uso da tecnologia melhora a qualidade e abre portas para produtos brasileiros no exterior. Boletim Informativo UFMG. Belo Horizonte, a. 31, n. 1468, jan. 2005. Disponível em: http://www.ufmg.br/boletim/bol1468/quinta.shtml. Acesso em 3 ago. 2010.

\section{LEONEL, F. R. Irradiação e qualidade da carne de frango congelada e embalada a} vácuo. 2008. Tese (Doutorado) - Universidade Estadual Paulista, Faculdade de Ciências Agrárias e Veterinárias, Jaboticabal.

LIMA, K. S. C.; GROSSI, J.; LIMA, A. L. S.; ALVES, P. E. M. P.; CONEGLIAN, R. C. C.; GODOY, R. L. O.; SABAA-SRUR, A. V. O. Efeito da radiação ionizante (Y) na qualidade pós-colheita de cenouras (Daucus carota I.) cv. Nantes. Campinas: Ciência e Tecnologia de Alimentos, v. 2, n. 2, 2001.

LOAHARANU, P. Cost benefit aspects of food irradiation. Food Technology, v. 48, n. 1, p. 104-108, 1994.

LOAHARANU, P.; MURREL, D. A. A role for irradiation in the control of foodborne parasites. Trends Food Sci. Technol., Cambridge, v. 5, p. 190-195, 1994.

MALISKA, C. Conservação de alimentos por irradiação. Revista Higiene Alimentar, v. 11 , n. 68-69, p. 16-17, 2000.

MARCHIONI, E.; HORVATOVICH, P.; CHARON, H.; KUNTZ, F. Detection of irradiated ingredients included in low quantity in non-irradiated food matrix. 2. ESR Analysis of mechanically recovered poultry meat and TL Analysis of Species. J. Agric. Food Chem., v. 53, p. 3774-3778, 2005.

MARCOTTE, J. W. JR. Irradiated strawberries enter the US market. Food Technology, v. 46, n. 5, p. 80, 1992.

MARFAK, T. Feasibility study of a commercial irradiation plant in Morocco. Rad. Phys. Chem., v. 63, p. 383-385, 2002.

MARTINOVICH, M. Como gerenciar capital de giro. Agenda do empresário. São Paulo, n. 11, p. 1-6, 1996.

MICROSOFT Excel 2010. Office Excel 2010 (software em português). Microsoft Corporation, 2010. Conjunto de programas. 1 CD-ROM.

MINITAB. 2008. Minitab for Windows [Minitab- Inc, USA] Versão 15. Enghish Ink Copyright [C]. 
MOTTA, R. R.; CALÔBA, G. M. Análise de Investimentos. $1^{a}$ ed. São Paulo, S.P.: Atlas, 2002.

MURANO, E. A.; HAAYES, D. J.; MURANO, P. S.; OLSON, D. G.; SAPP, S. Food Irradiation - A sourcebook. USA: Ames, 1995.

NORONHA, J. F. Projetos agropecuários: administração financeira, orçamento e viabilidade econômica. $2^{\text {a }}$ ed. São Paulo: Atlas, 1987.

ORNELLAS, C. B. D., GONÇALVES, M. P. J., SILVA, P. R., MARTINS, R. T. Atitude do consumidor frente à irradiação de alimentos. Ciência e Tecnologia de Alimentos. Campinas, v. 26, n. 1, p. 211-213, 2006.

PEARCE, D. W. Economics of natural resources and the environment. Baltimore: Johns Hopkins University Press, 1990.

POHLMAN, A. J.; WOOD, O. B.; MASON, A.C. Influence of audiovisuals and food samples on consumer acceptance of food irradiation. Food Technology, v. 48, n. 12, p. 46-49, 1994.

PSZCOLA, D. E. 20 ways to Market the concept os Food irradiation. Food Technology, v. 51, n. 2, p. 46-48, 1997.

PSZCZOLA, D.E. Irradiated poultry makes U.S. debut in Midwest and Florida markets. Food Technol., Chicago, v. 47, n. 11, p. 89-92, 94, 96, 1993.

PSZCZOLA, D.E. Irradiated produce reaches Midwest market. Food Technol., Chicago, v. 46, n. 5, p. 89-92, 1992.

RAMOS, S. Y. Avaliação da localização de Packing houses no Estado de São Paulo: o caso da laranja de mesa. 2001. Dissertação (Mestrado) - Escola Superior de Agricultura "Luiz de Queiroz", Universidade de São Paulo.

RELA, R. P.; CALVO. W. A. P.; NAPOLITANO, C. M.; KODAMA, Y.; OMI, N.M.; COSTA, F. E. Programa de qualificação de um irradiador multipropósito de Cobalto-60 tipo compacto. In: INTERNATIONAL NUCLEAR ATLANTIC CONFERENCE - INAC. 2005.

RESURRECCION, A. V. A.; GALVEZ, F. C. F.; FLETCHER, S. M.; MISRA, S. K. Consumer attitudes toward irradiated food: Results of a new study. J. Food Prot., Ames, v.58, n. 2, p. 193-196, 1995.

ROZENFELD, H.; FORCELLINI, F. A.; AMARAL, D. C.; TOLEDO. J. C.; SILVA. S. L.; ALLIPRANDINI. D. H.; SCALICE. R. K. Gestão de Desenvolvimento de produtos: Uma referência para a melhoria do processo. $1^{\underline{a}} \mathrm{ed}$. São Paulo: Saraiva, 2006.

SANTOS, A. F., VIZEU, D. D., DESTRO, M. T., FRANCO, B. D. G. M., LANDGRAF, M. Determinação da dose de radiação gama para reduzir a população de Salmonella ssp em 
carne de frango. Ciência e Tecnologia de Alimentos. Campinas, v. 23, n. 2, maio/ago. 2003.

SHULTZ, H. G.; BRUHN, C. M.; DIAZ-KNAUF, K. V. Consumer attitudes towards irradiated foods: Effects of labeling and benefits information, Food Technology, v. 43, p. 80-86. 1989.

SPOLAORE, A. J. G.; GERMANO, P. M. L.; GERMANO, M. I. S. Irradiação de Alimentos. In: GERMANO, P. M. L.; GERMANO, M. I. S. Higiene e Vigilância Sanitária de Alimentos. São Paulo, Varela, p. 421-442, 2001.

TÉBÉKA, I. R. M.; HALLWASS, F. Radiações Nucleares: Histórico e Aplicação Industrial na Preservação de Alimentos. In: I CONGRESSO NORTE NORDESTE DE QUÍMICA. Universidade Federal de Pernambuco - Departamento de Química Fundamental, 2007.

TERRY, D. E.; TABOR, R. L. Consumer Acceptance of Irradiated produce: A Value Added Aproach. Produce Marketing Association Yearbook, p. 42-47, 1998.

URBAIN, W.M. Food Irradiation. Orlando: Academic Press, 315p. 1986.

VILLACICENCIO, A. L. C. H. Avaliação dos efeitos da radiação ionizante de $60 \mathrm{Co}$ em propriedades físicas, químicas e nutricionais dos feijões Phaseolus vulgaris $L$. Vigna unguiculata (L.) Walp. 1998. Tese (Doutorado) - FCF/USP, São Paulo.

VILLAVICENCIO, A. L. C. H.; ARAUJO, M. M.; FANARO, G. B.; RELA, P. R.; MANCINIFILHO, J. Sensorial analysis evaluation in cereal bars preserved by ionizing radiation processing. Rad. Phys. Chem., v. 76, p. 1875-1877, 2007.

VILLAVICENCIO, A.L.C.H.; MANCINI-FILHO, J.; DELINCÉE, H. Application of a rapid screening method to detect irradiated meat in Brazil. Rad. Phys. Chem. v. 57: 3-7, p. 295-298, 2000.

WHO - World Health Organization. Disponível em: http://www.who.int. Acesso em: 04 fev. 2010.

WHO - World Health Organization. Inocuidad e Idoneidad Nutricional de los Alimentos Irradiados. Genebra, 172p. 1995. 